\title{
التثاقف من مسلوبية الاحتواء إلى معقولية التعارف
}

\section{الحاج بن أحمنه دواق}

\section{الملخص}

تسعى هذه المقالة إلى بيان طبيعة الصلات الحضارية، وضرورتها التاريخية، والخلفية الحضارية المؤسسة لطبيعة

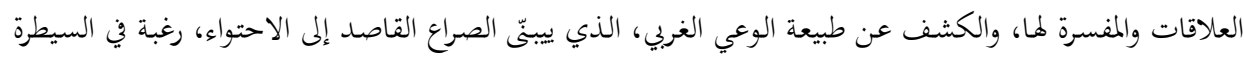

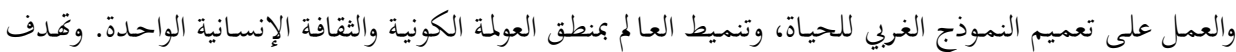

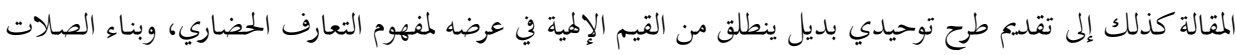

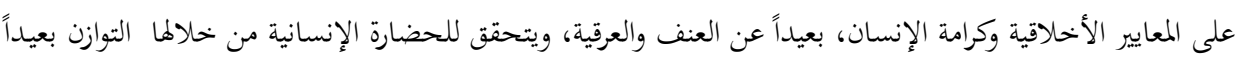

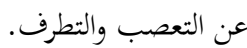

الكلمات المفتاحية: التثاقف، التعارف الحضاري، الحوار الحضاري، النموذج الحضاري الغربي، العولمة والعالمية،

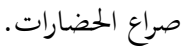

\section{Abstract \\ Acculturation; from alienative assimilation to reasonable acquaintance}

This article aspires at the understanding of the nature of civilizational relations, its historical necessity and the civilizational background that establishes such relations and explains them. It also attempts to uncover and challenge the position of Western consciousness that aims at assimilating the world, through forcing its culture life styles and values. The article provides and Tawhidi alternative based on the Divine Values, through presenting the concept of civilizational acquaintance that builds relations on tolerance morals and human dignity, away from violence, extremism and racism.

Keywords: Acculturation, Civilizational dialogue, Civilizational acquaintance, Western civilizational model, Globalization and universalism, Clash of civilization.

" أستاذ الكلام الإسلامي وفلسفته، بجامعة باتنة- الجزائر. البريد الإلكتروني: elhadj_1971@yahoo.fr

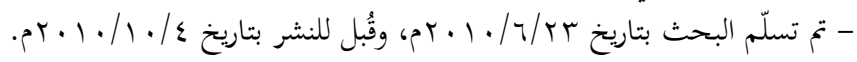




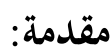

كمـا هـو دارج في أدبيـات الفكر، تتأسس حيـاة الإنسـان على منظومـات قيميـة

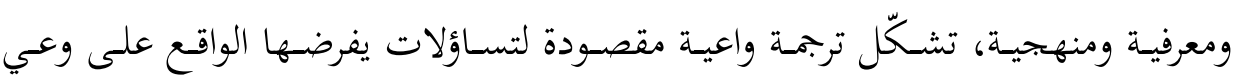

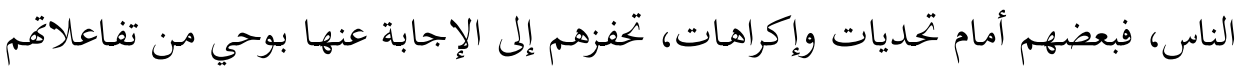

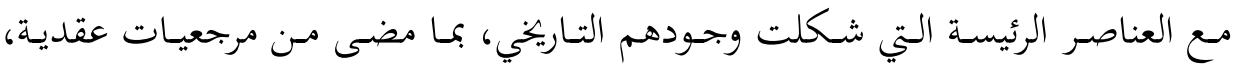

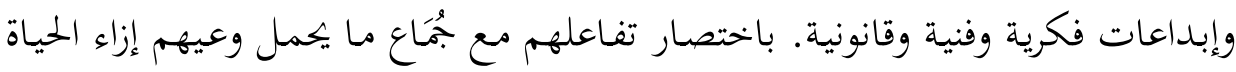

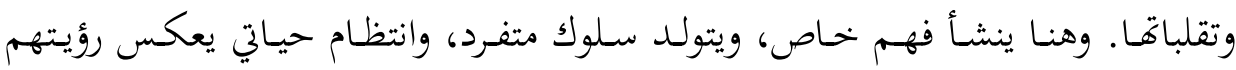

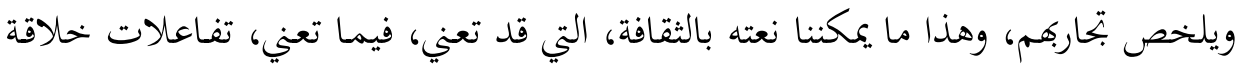

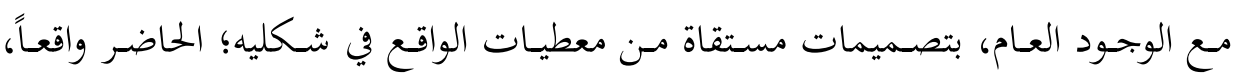

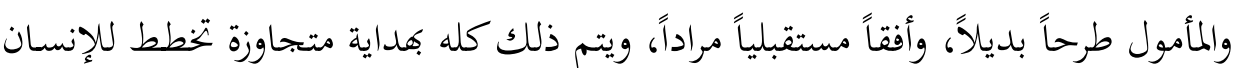

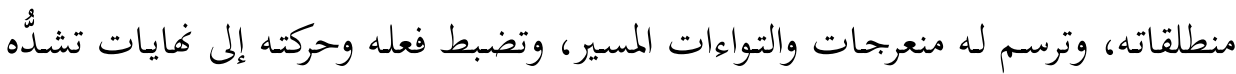

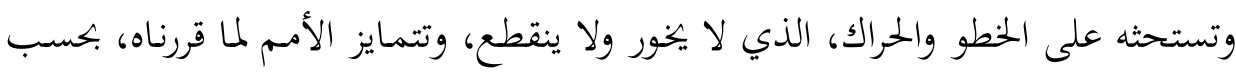

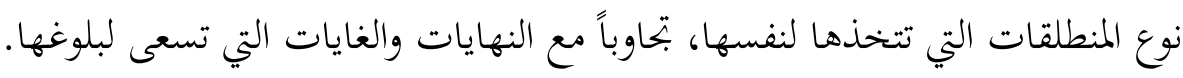

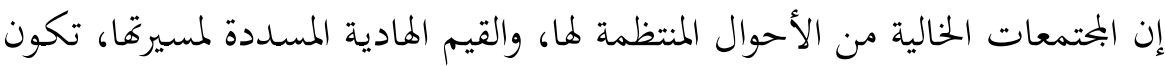

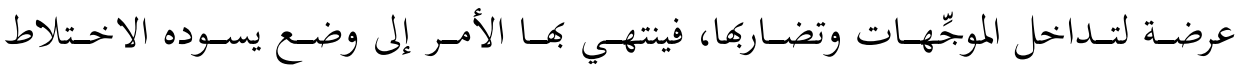

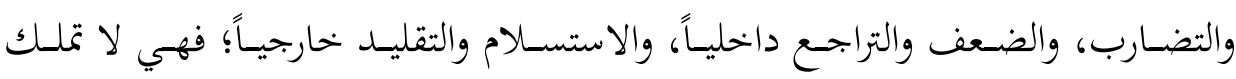

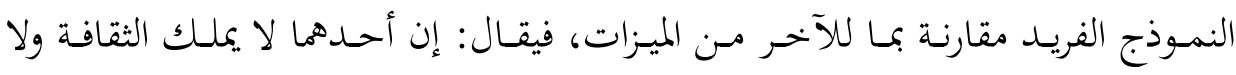

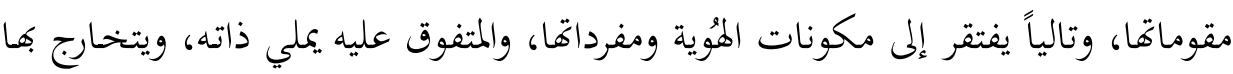

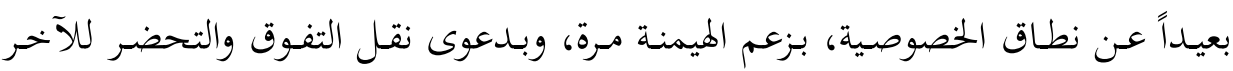

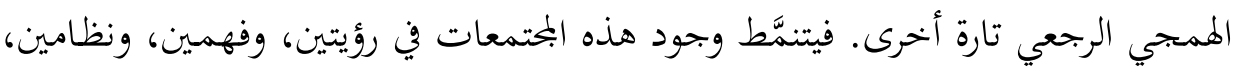

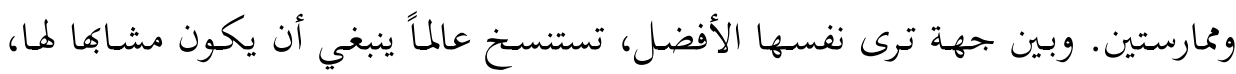

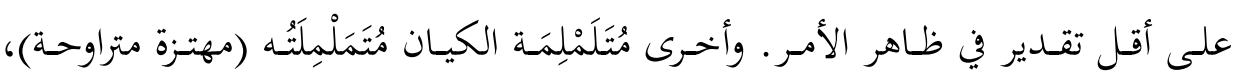

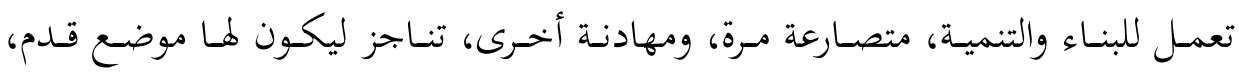

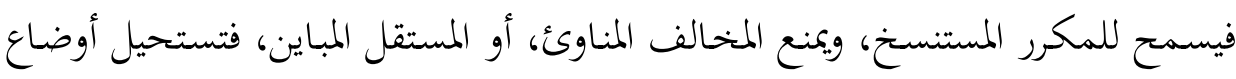




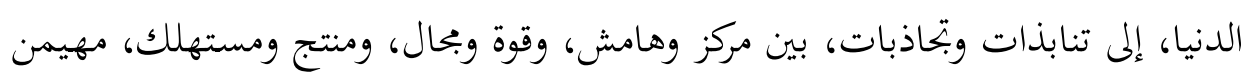

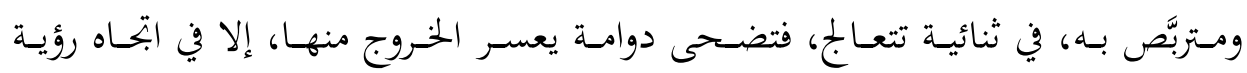

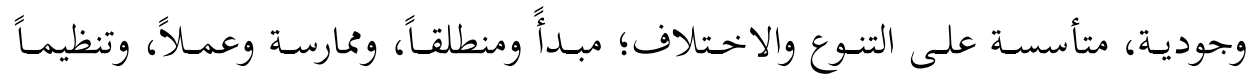
وحُكْمَاً، ومساهمةً وإضافةً، وغايةً ونُشَداناًا.

ويمكن أن نقرر بادئ الأمر أن شكل العلاقات الإنسانية، أو الثناقف، في نطاق

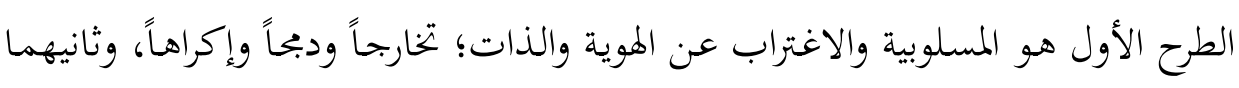

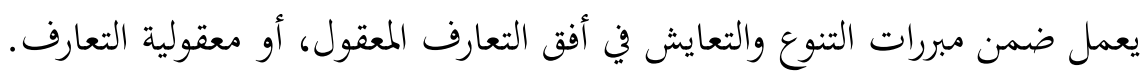

\section{أولاً: في حقيقة المثاقفة، وماهية التثاقف}

يُطلق على العلاقات الثقافية مصطلح "المثاقفة"، و"الثثاقف". وجوهر التمايز بينهما

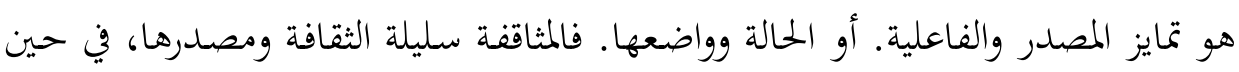

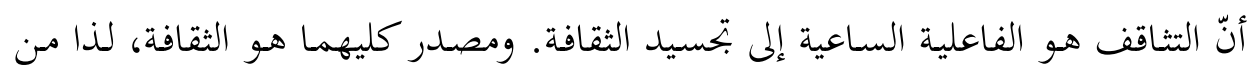
الضروري التعريج على المصطلحات الثلاثة باقتضاب.

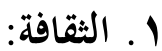

جـاء في لسـان العرب، في تصريفات كثيرة للفظة الثقافة، أهـا مشتقة مـن "ثقفـ

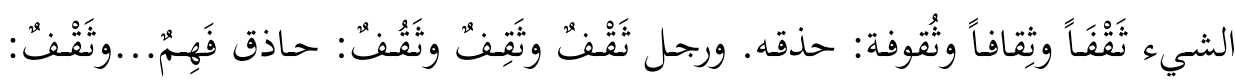

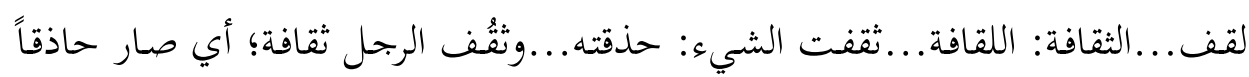

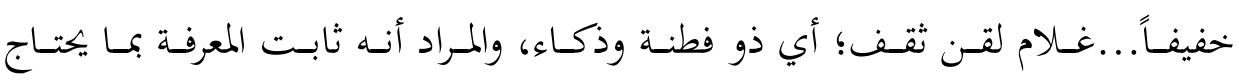

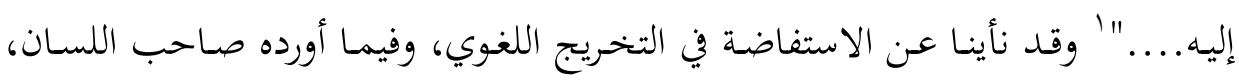

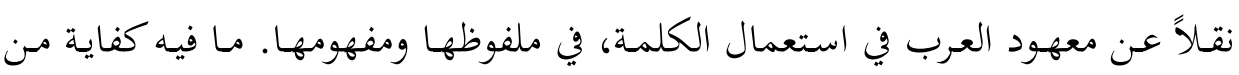

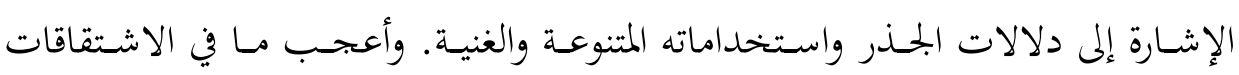

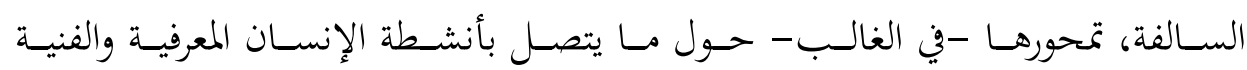


والسلوكية، ما يفيد شمولية المعاني المتضمنة في مثويّات الكلمة في المستوى اللغوي، ناهيك بما يمتد إلى المعاني التي يتم استحضارها في السياقات الفكرية المختلفة.

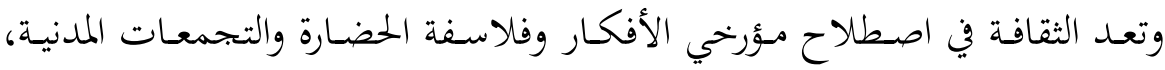

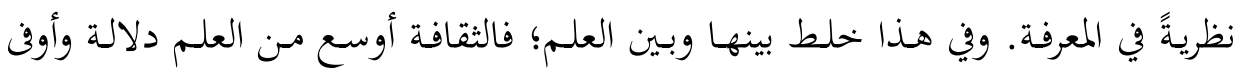

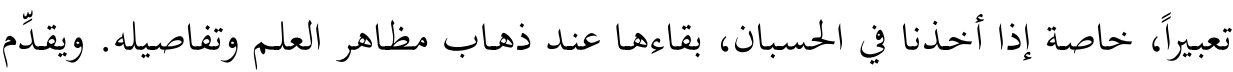

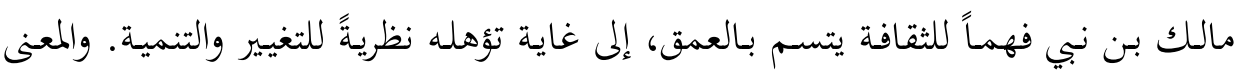

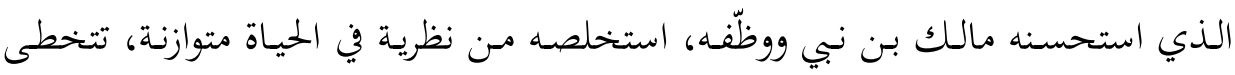

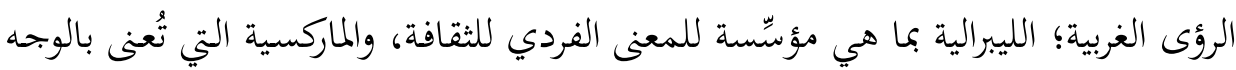

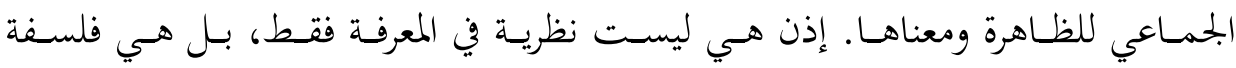

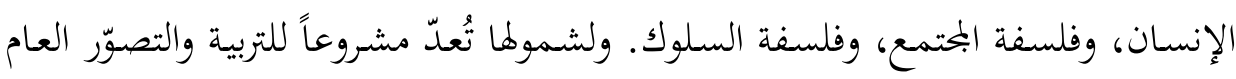

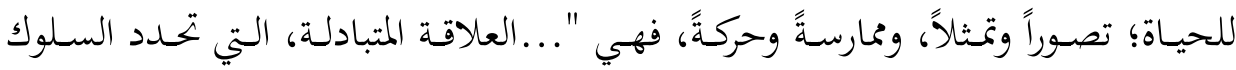

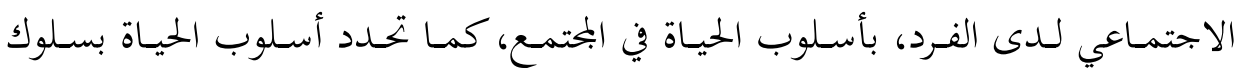
الفرد."الاجتاعي

فالثقافة إطار يتلقى فيه الأفراد هُوياتم، وطريقة تفكيرهم، ونمط معيشتهم، بالارتباط

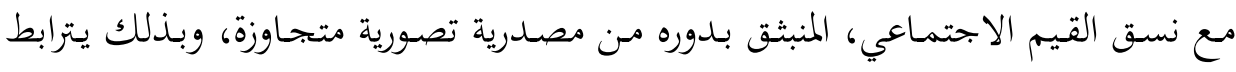

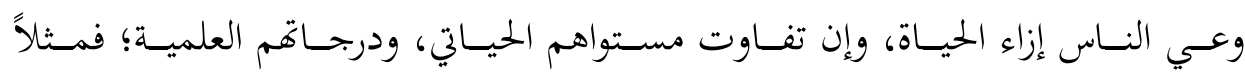

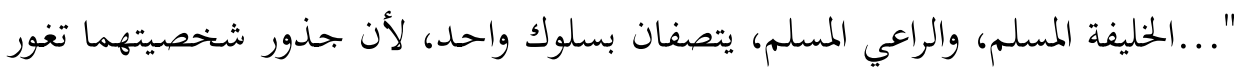

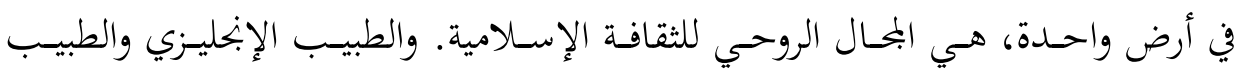

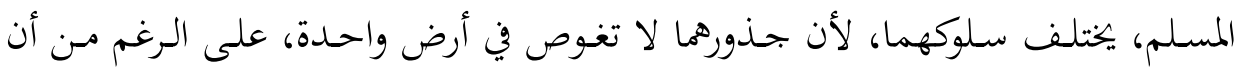

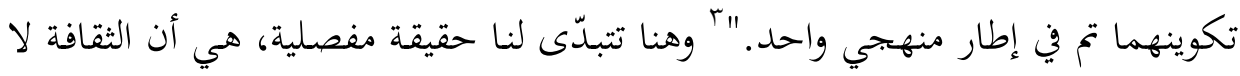

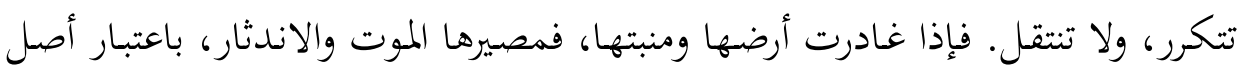

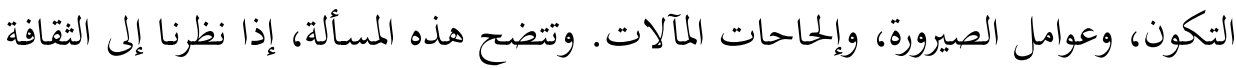

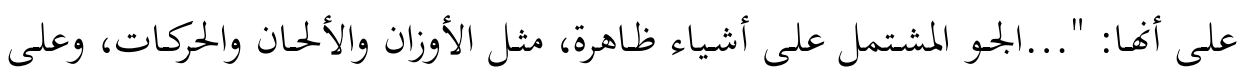

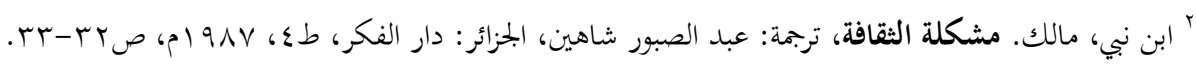

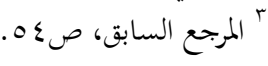


أشياء باطنة كالأذواق والعادات والتقاليد، بمعنى أهما الجحو العام الذي يطبع أسلوب الحياة

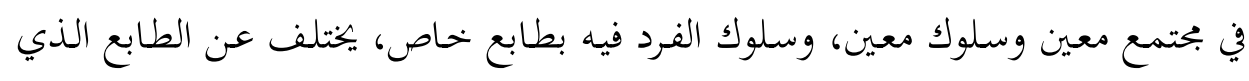

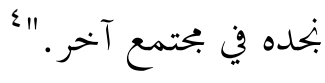

فالخصوصية مسن أجلى سمـات الثقافة وألصقها بمفهومها، خلافاً للعلم، الذي قد يتسم بشيء من العمومية والكُلّية، والاشتراك الإنساني العام فيه. ولن يفضي تحليلنا إلى الى

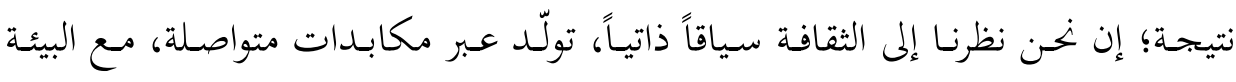

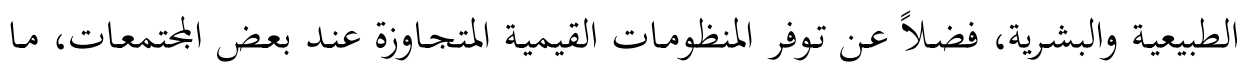

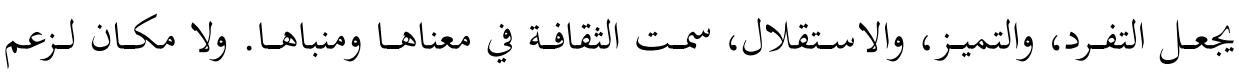

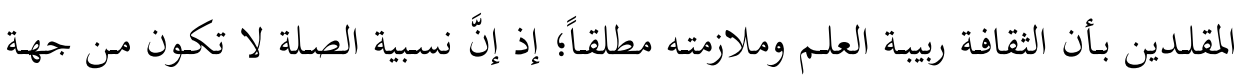
شروط ضمان نشأة العلم وتطوره، أما أن يؤخذ العلم بملحقاته المعنوية والرؤيوية، فهذا من الخطورة بمكان، وبالقدر المفضي إلى التقليد الأعمى المهلك. "...إن السلوك الاجتماعي للفرد خاضع لأشياء أعم من المعرفة، وأوثق صلة بالشخصية منها بجمع المعلومات، وهذه هي الثقافة التي تعني بحموعة من الصفات الخلقية، والقيم الاجتماعية، التي تؤثر في الفرد

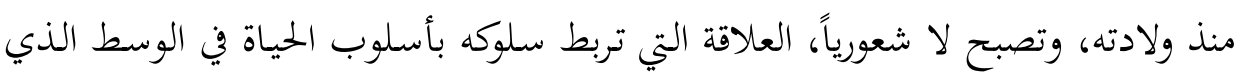
ولد فيه.

تشـمل الثقافة في هـا المنظور بعدين أساسـين يكّونان الحياة، هما؛ أن الثقافة محيط

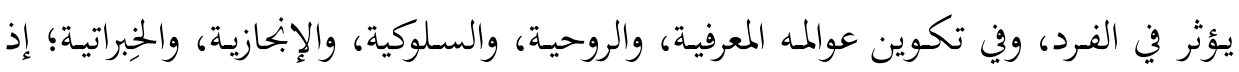

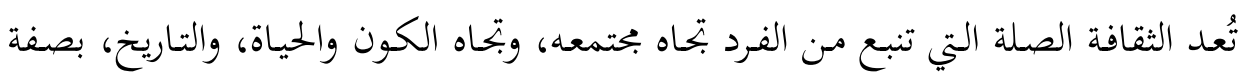

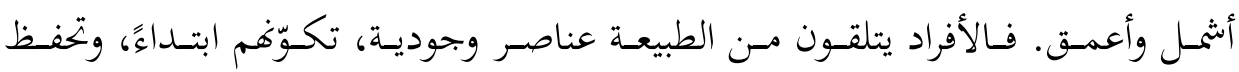

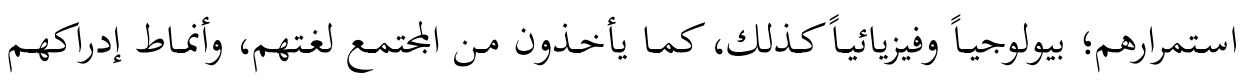

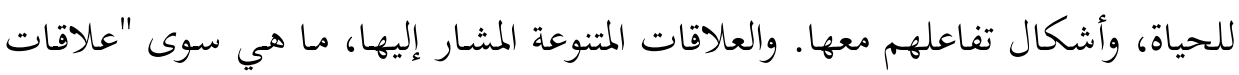
ثنافية، أعني أهـا خاضعة لأصول ثنافة معينة...حيث قلنا: إن الثقافة هي المحيط الذي 
يصوغ كيان الفرد، كما أفها بحموع مـن القواعد الأخلاقية والجمالية." "وتدور العلاقات في إطار من الأخلاقية التّي تنشد المعنى، في طبيعة الارتباطات، وتنشد العلاقة الجمالية في

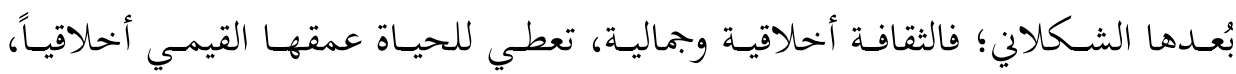

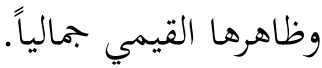

فالثقافة قوة مؤسِّسة وحرَّكة أولى للمجتمعات والحضارات، على الرغم مما للعوامـل

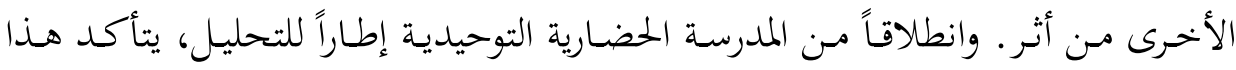
المنحىى للثقافـة والتنـافس، بكونـه وسـيلة تواصـل. ومسن غـير العـدل تعمـيم الخصوصسية،

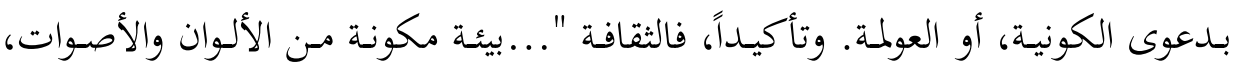
والأشـكال والحركات والأشـياء المأنوسـة، والمنـاظر والصـور، والأفكـار المتفشـية، في كـل ابتحاه...صورة خياليـة...تمارس مفعولها على الراعي وعلى العالم بالسواء، وهي الوسط الذي يتشكل داخله الكيان النفسي للفرد، بالصورة نفسها التي يقيم بها تشكل كيانه

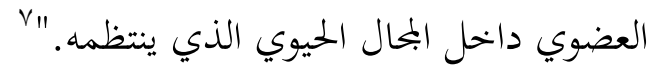

التعريفات التي أوردناها، على اقتضابها، تحدد مفهوم الثقافة في صورة تعكس حضارة ما يتحرك في نطاقها الإنسان المتحضر، ويسلك وفقها، في جدلية فردية جماعية، لا تلغي الواحد لحساب الآخر والعكس، في انسجام تحدثه الدفعات الروحية المتتالية، المأخوذة من في ونس مرجعية الجمماعة الإنسانية، حينما يؤذن فجر حضارة جديدة. ويعرّف محمـد عابـد الجحابري الثقافـة بأفها: "ذلك المركَّب المتجـانس مـن: الذكريات والتصورات والقيم والرموز والتعبيرات والإبداعات والتطلّعات التي تحتفظ لجماعة بشرية،

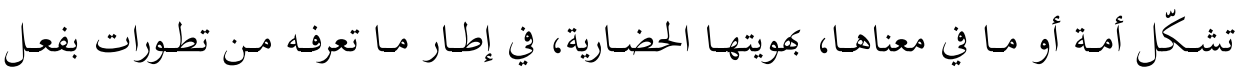
ديناميتها الداخلية وقابليتها للتواصل والأخذ والعطاء. وبعبارة أخرى: الثقافة هي الـمُعبِّ

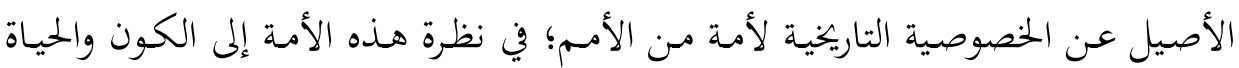

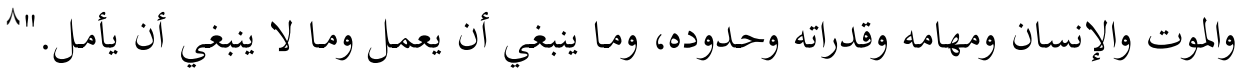

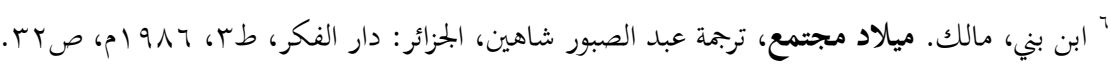

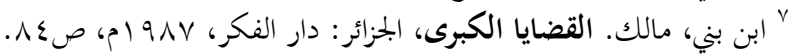

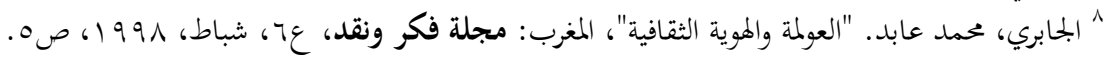




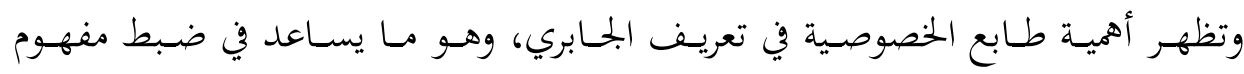
التثاقف، وتعيين حدوده؛ رفعاً للإشكالات العالقة.

\section{r T المثاقفة والتثاقف:}

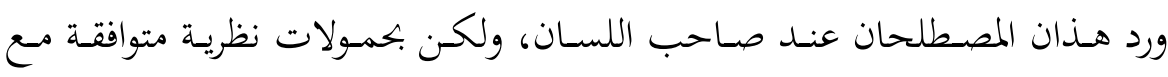

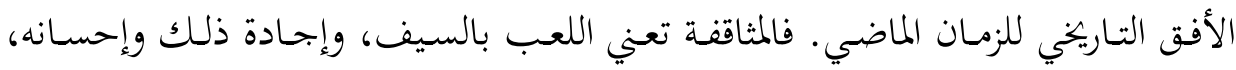

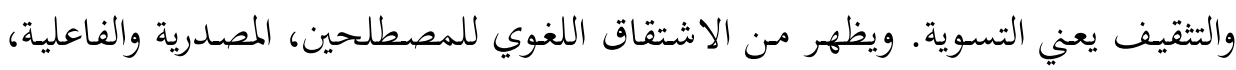

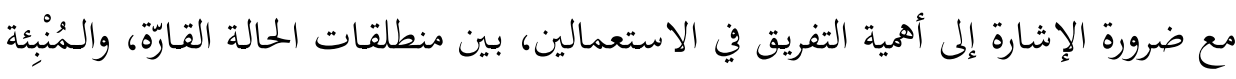
عن شكل صلات وعلاقات بين بحتمعات مختلفة من جهة، وتفعيل تلك العلاقة والإثمار

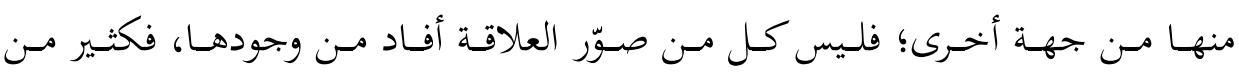

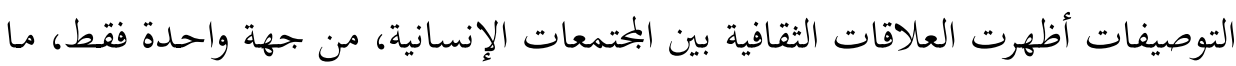

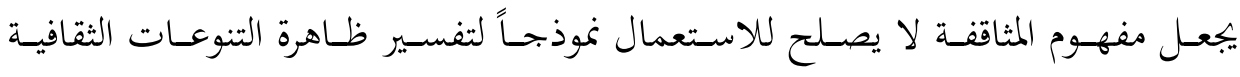

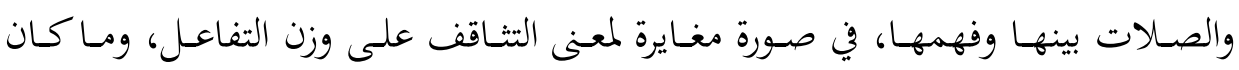

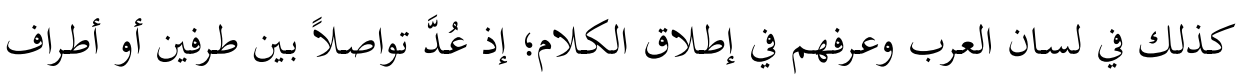

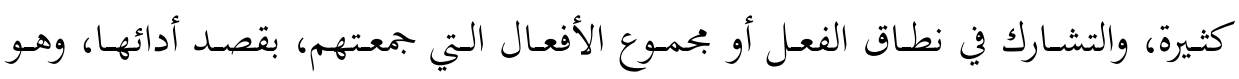

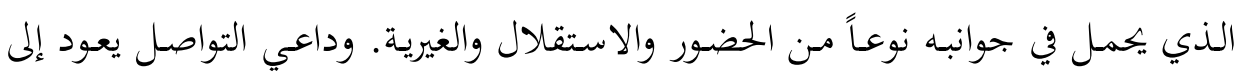

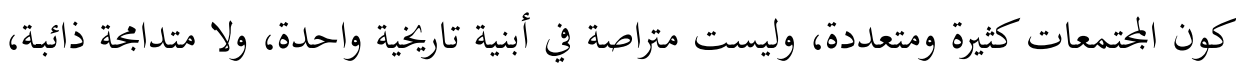

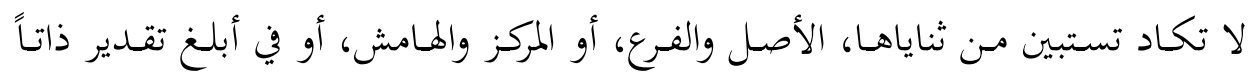
وأخرى.

ومن هنا تكون المثاقفة -توافقاً مع المفاعلة، بوضع أدنى إلى الغياب والضمور - حالةً

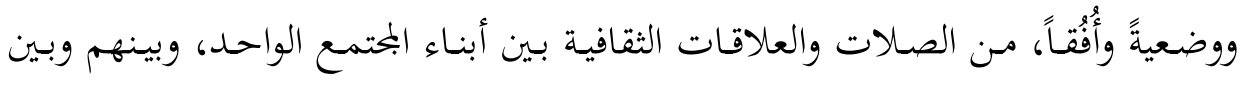

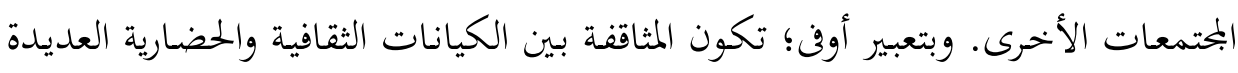

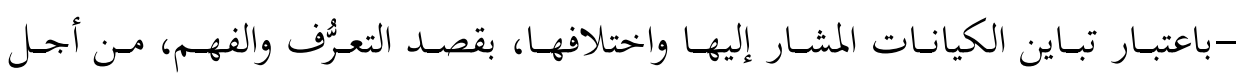

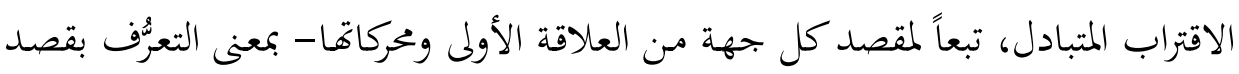

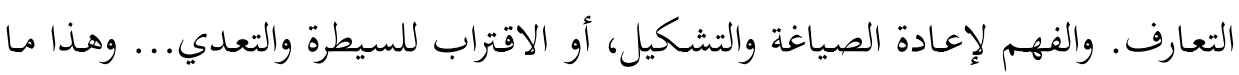




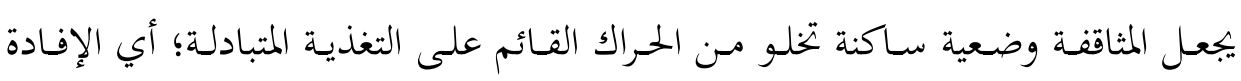
المزدوجة والواعية، وتتلاف السير في ابحاه واحد؛ فهماً، وحكماً، وصلة.

ويغدو التحليل أكثر وضوحاً إذا عددنا المثاقفة جماع الظواهر التي تستبطن الصلات

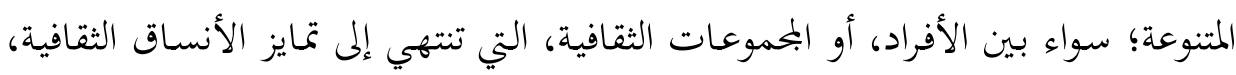

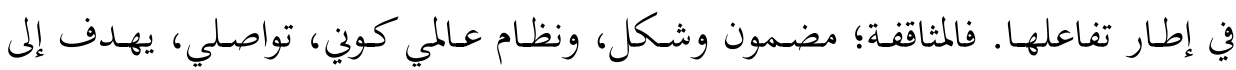

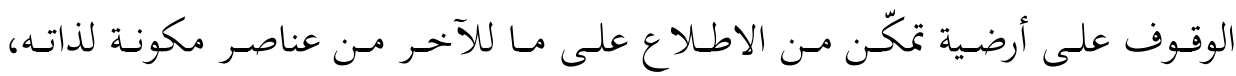

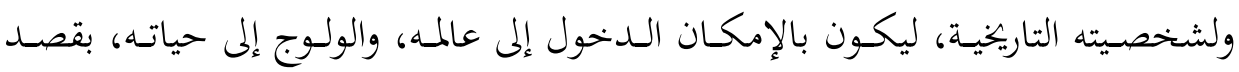

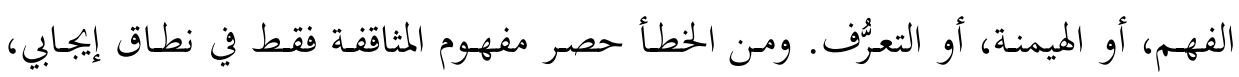
فقد يحمل معنئ سلبياً، على مستوى التصور، والحركة أيضاً. ومصطلح المثاقفة يتّسع لكثير مـن الـدلالات، منها: الاقتراب، والتميز، والتبـادل

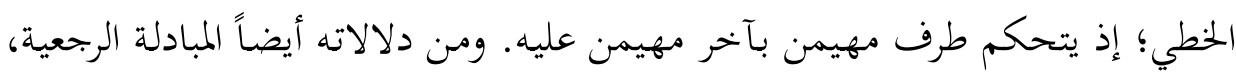

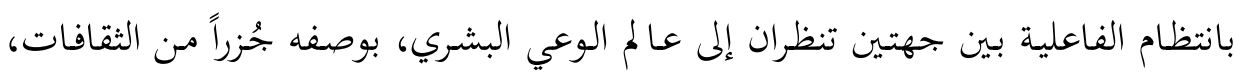

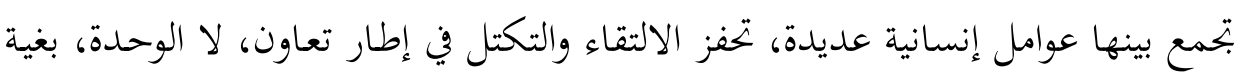
القضاء على مشكلات التنمية الحضارية للبشرية، تقليلاً لعوامل الصدام والصراع.

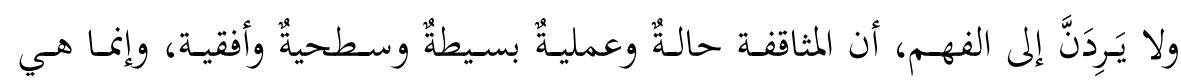

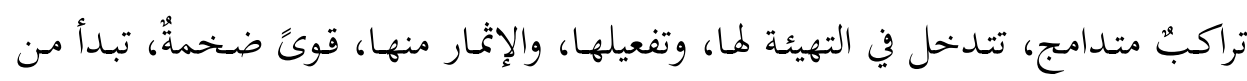

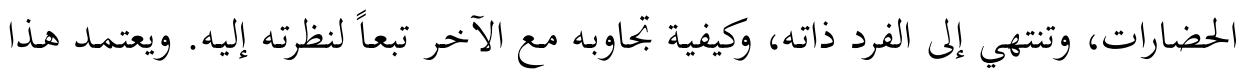

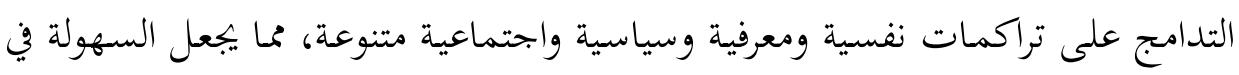

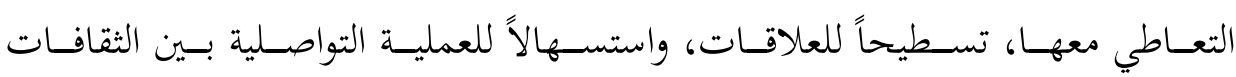

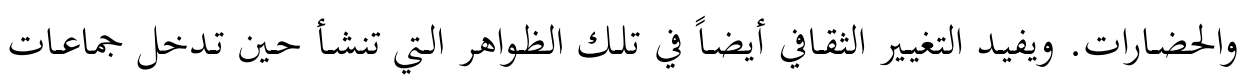

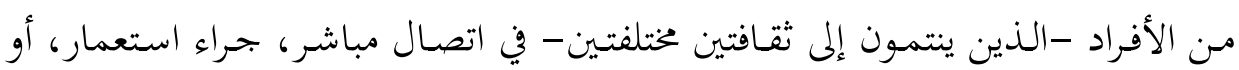

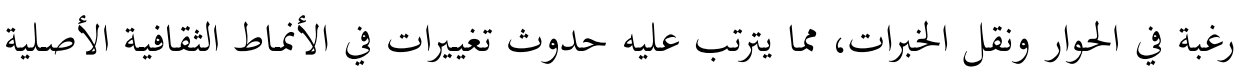

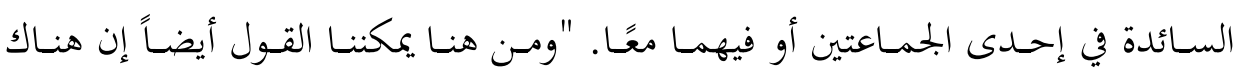

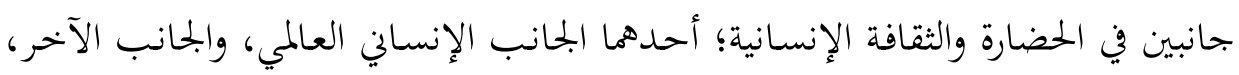


الجحانب القومي، أما الفرق بينهما فهو أن الحضارة القومية حضارة وثقافة انشعابية، فيما

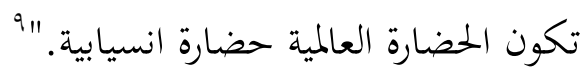

والتثاقف شكل من الفِعل العالمي، الناجم عن إدراك التميز، والاستقلال الحضاري،

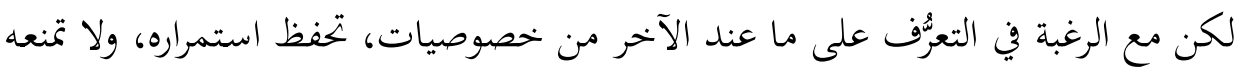

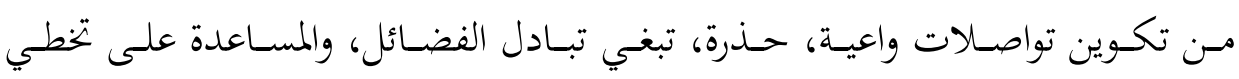
المشكلات.

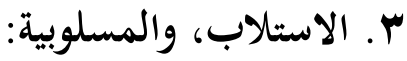

مـن المفــاهيم الملازمـة للصـلات الثقافيـة أو التثـاقف، الاسـتلابُ، ووجهرهـا الثـاني

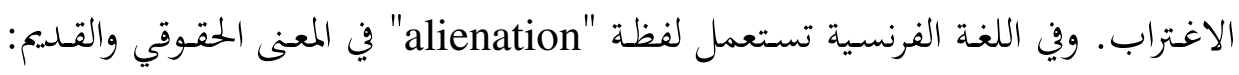

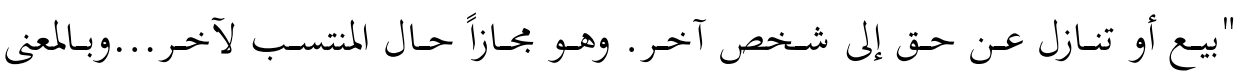

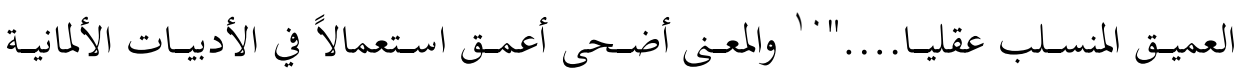

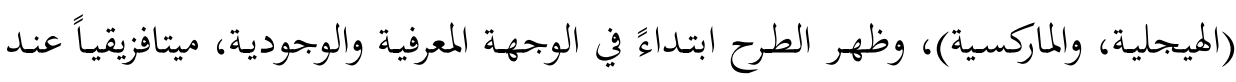

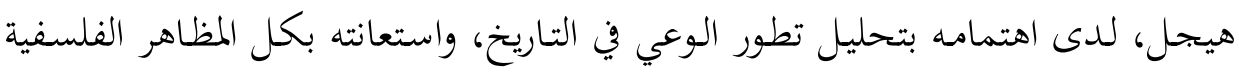

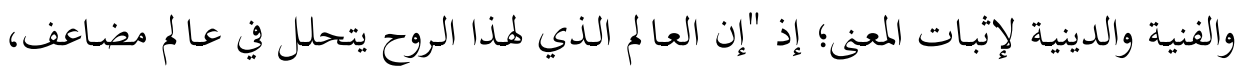

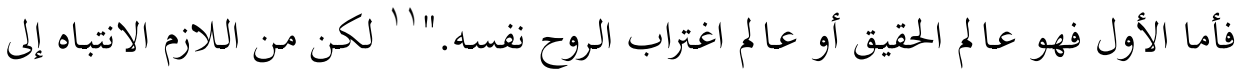

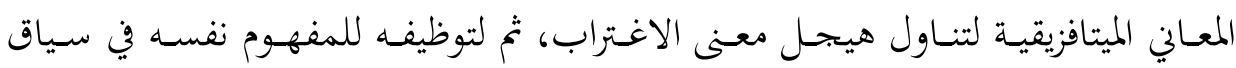

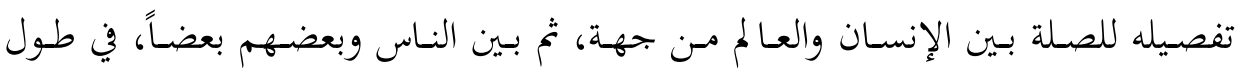

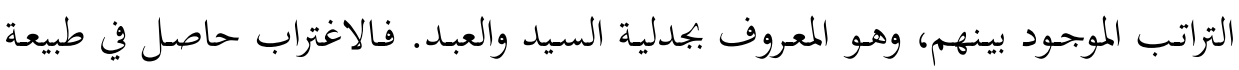

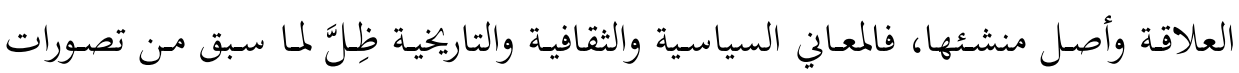

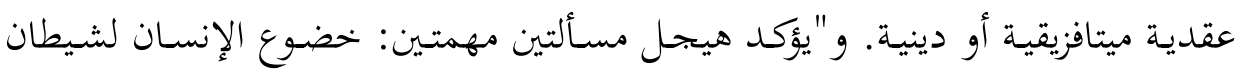

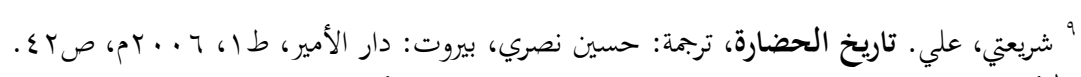

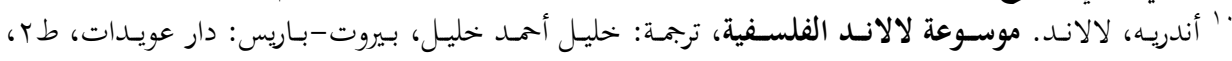

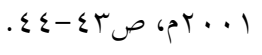

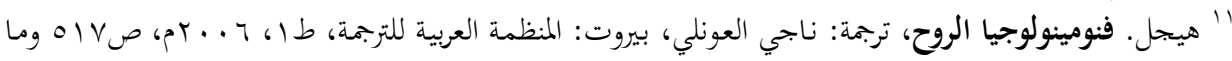




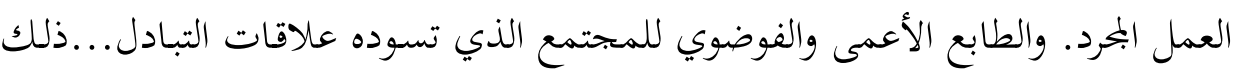

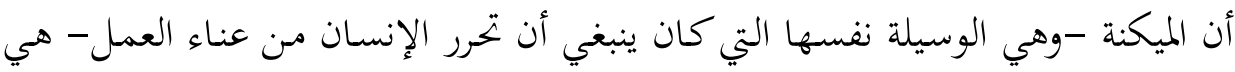

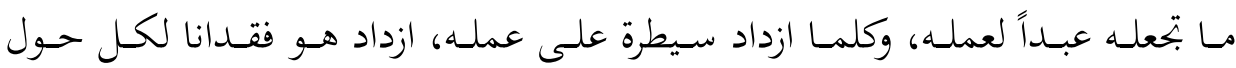
وقوة." 'ا ويؤكد ماركس معنى المثاقفة في إطار تحليلي مختلف، لغاية أيديولوجية. وتطور معسنى المثاقفـة للدلالـة على المعـاني الحضـارية المفتوحسة. بمعنى أن الكيانـات

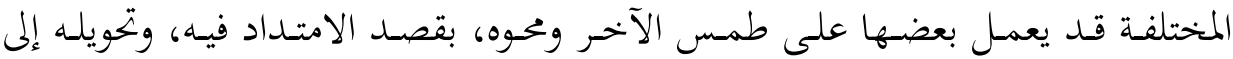

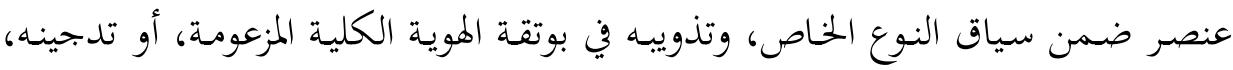

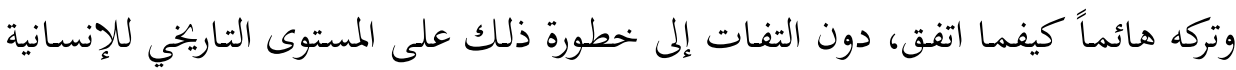

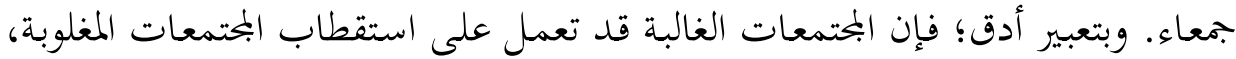

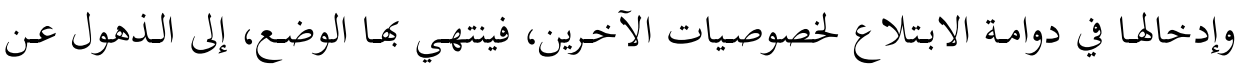

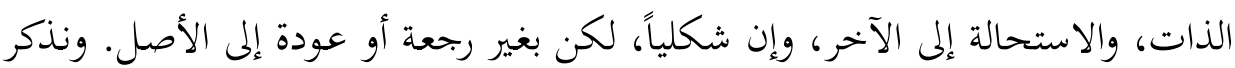

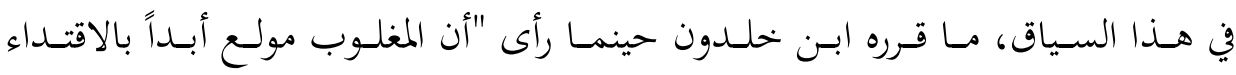

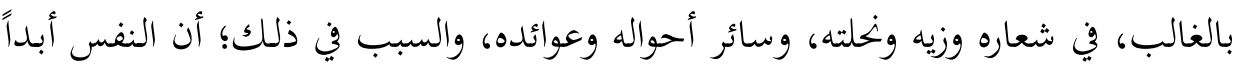

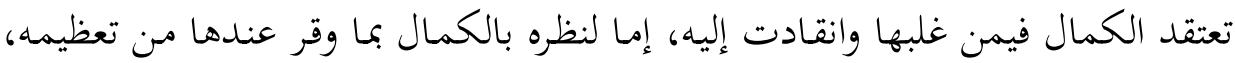

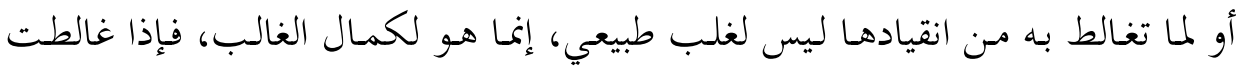

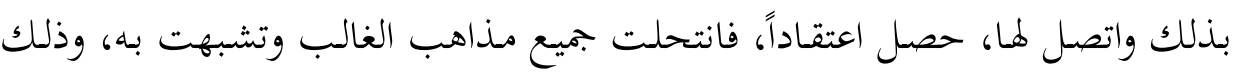

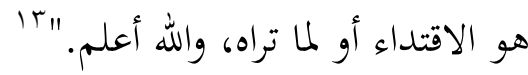
وأزعم أن أول محدد لمفهوم الاستلاب والاغتراب، هو ابن خلدون، -رغم أن النبي

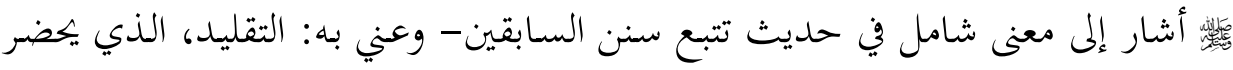

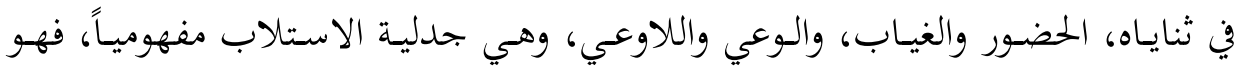

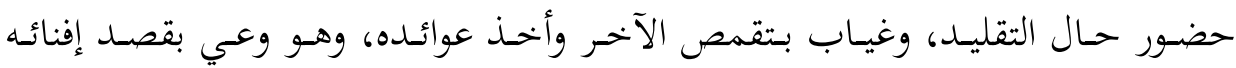

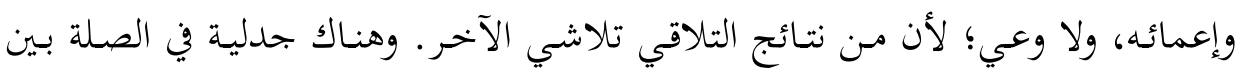
"' مركيوز، هربرت. العقل والثورة، هيجل ونشأة النظرية الاجتماعية، ترجمة: فؤاد زكريا، القاهرة: الهيئة العامة للتأليف

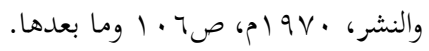
"' ابن خلدون، عبد الرمن. تاريخ ابن خلدون، السعودية: بيت الأفكار الدولية،، د.ت، صVV. 


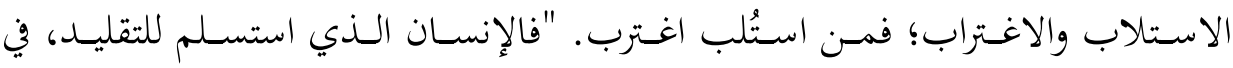

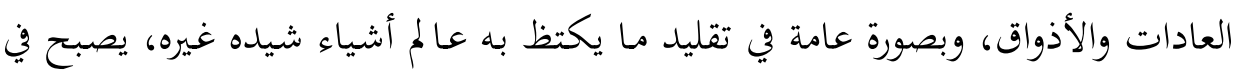

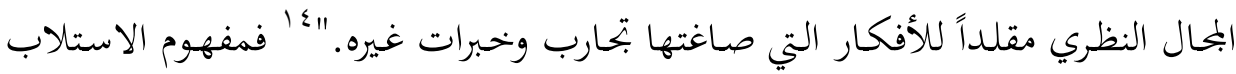

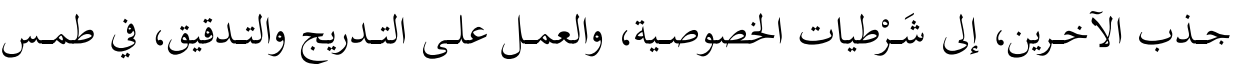

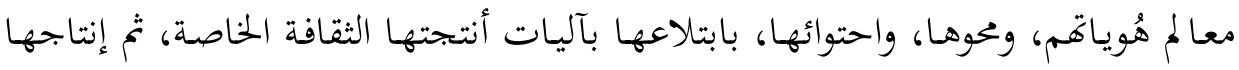

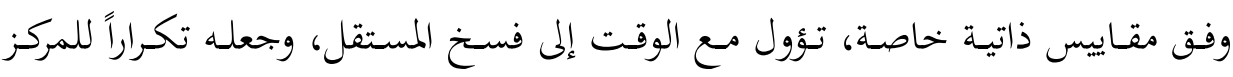
وتقليداً له.

وسعياً إلى التعميق في الطرح، نوضح مفهوم الاغتراب/ الاستلاب. "ففي الاستعمال

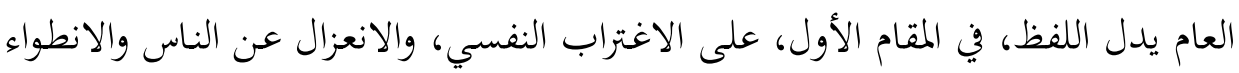

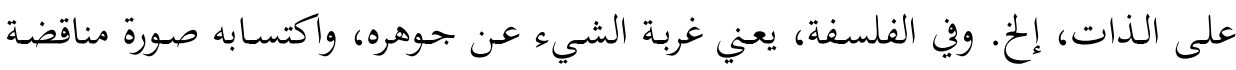

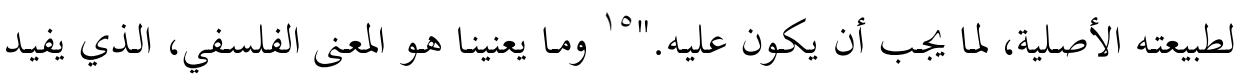

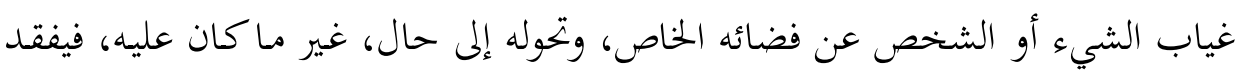
ذاته ويصير إلى غير ما عليه الآخر.

أمـا المسلوبية على وزن المفعولية، فهي نتاج الاستلاب الواعي، وهي حالة تُورِث

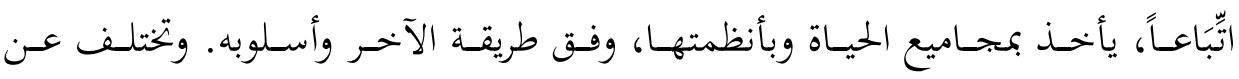

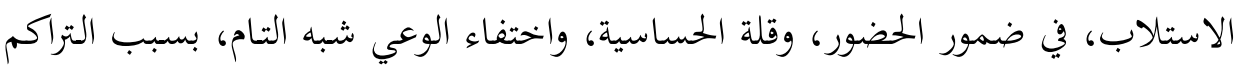

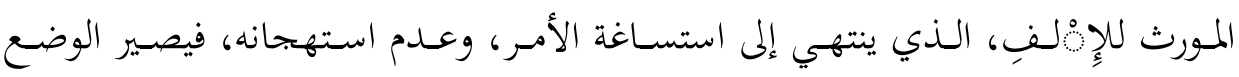

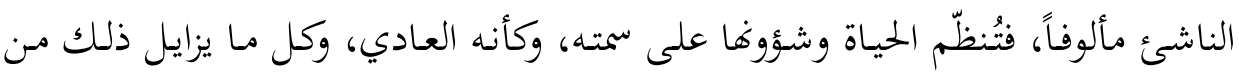

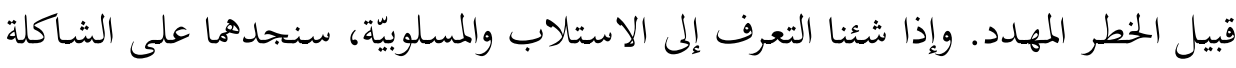

$$
\text { الاستلاب: وعي+ أدوات = نتيجة مقصودة }
$$

المسلوبية: نتيجة = لا وعي+ أدوات في الغالب للآخر.

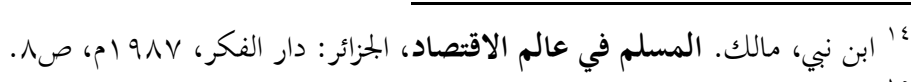

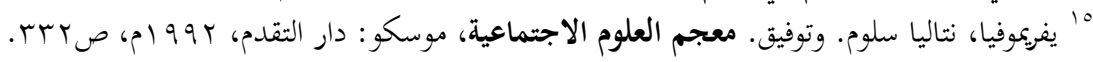




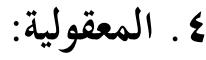

أعني بالمعقولية، دائماً على وزن المفعولية، العملية التي يُصار إليها بأداءات مركبة،

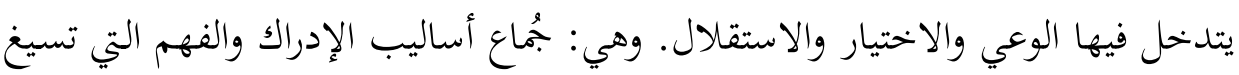

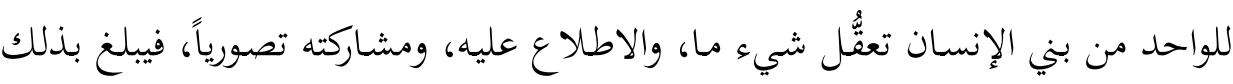

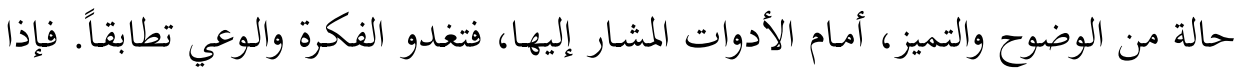

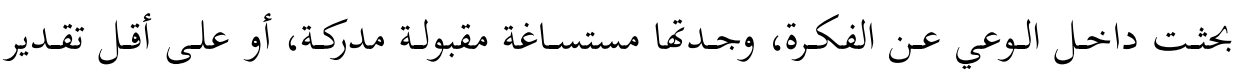

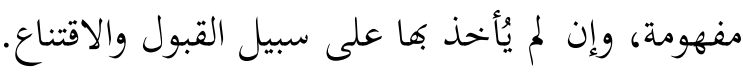

مـا يـراد هنـا مـن مسـمى المعقوليـة، لـيس لازمـة العقـل مسن حيـث مـا هـو، وإنمـا

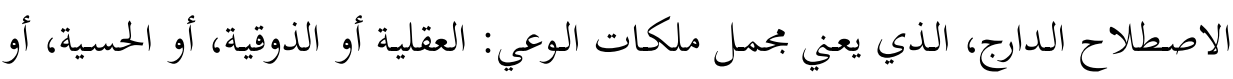

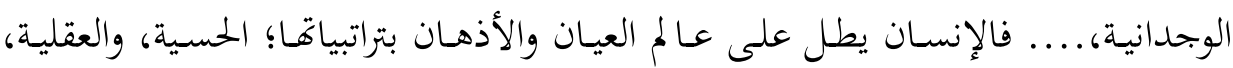

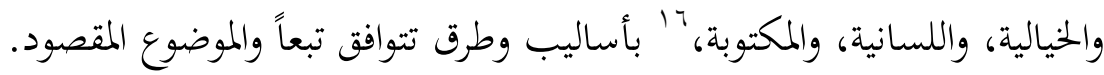
وعندما ربطت بين التعارف والمعقولية، فأنا أعني بها أن تأكيد الفكرة، لا يحتاج إلى لي

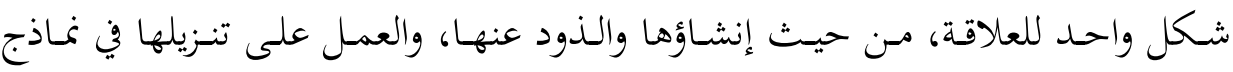

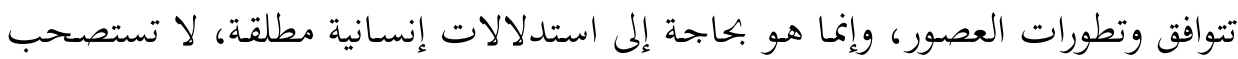

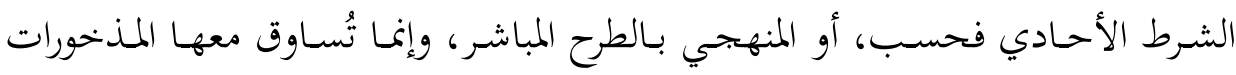

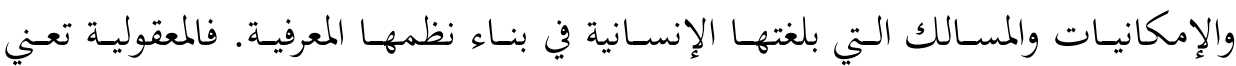

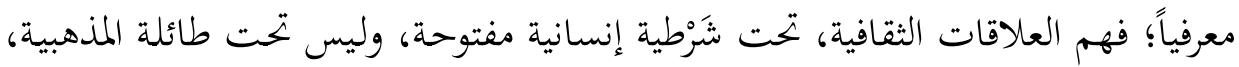

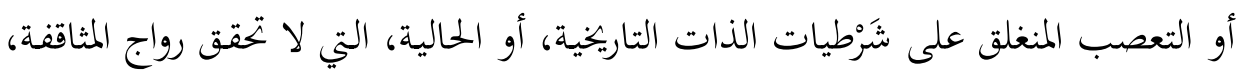
كما ستحققها اللازمات الإنسانية للتثاقف المفتوح.

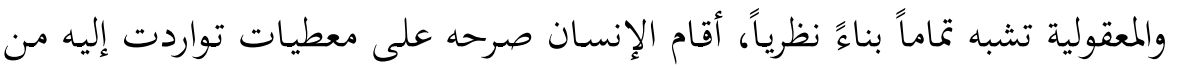

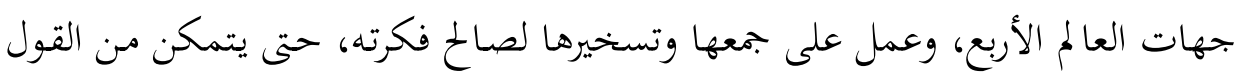

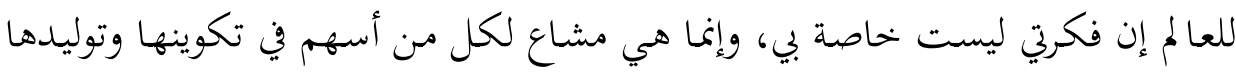
"17 الغزالي، أبو حامد. فيصل النفرقة بين الإسلام والزندقة، فصل في المصدقين، بحموع رسائل الغزالي، بيروت: دت،

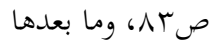




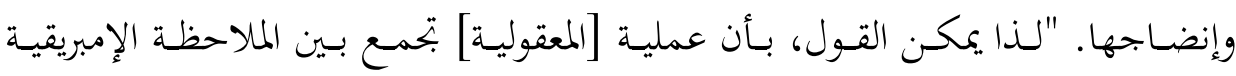

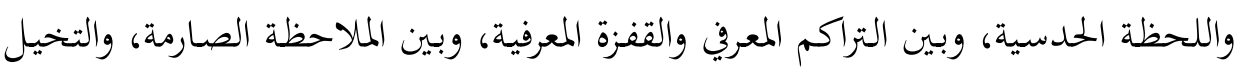

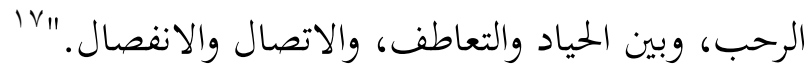

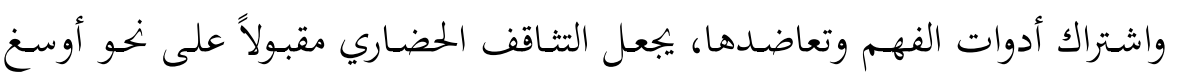

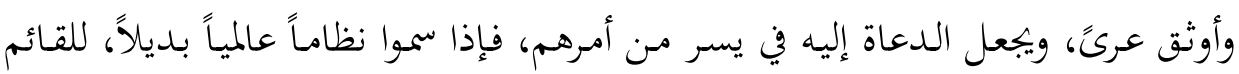

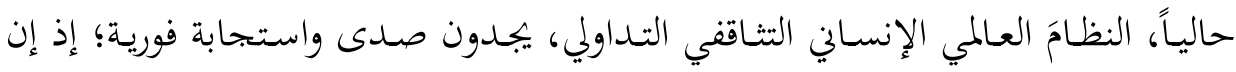

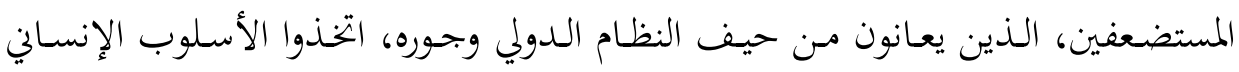
المفتوح في تأسيس مشروعية التثاقف.

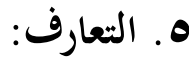

يُعد زكي الميلاد مـ المفكرين المنتمين إلى المدرسة التوحيدية المعاصرة، الذين وعوا

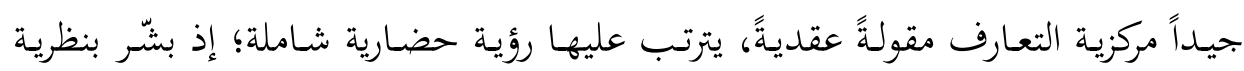

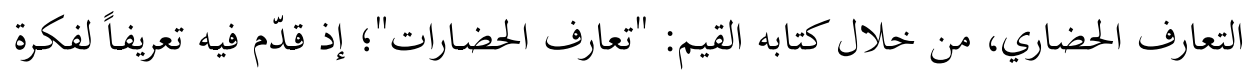

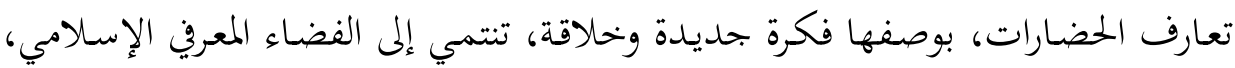

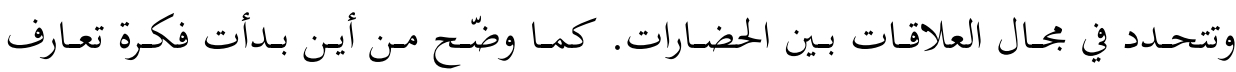

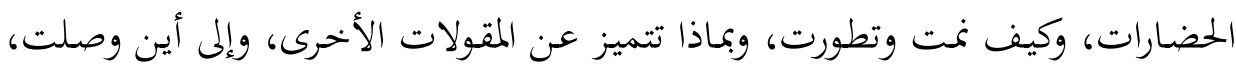

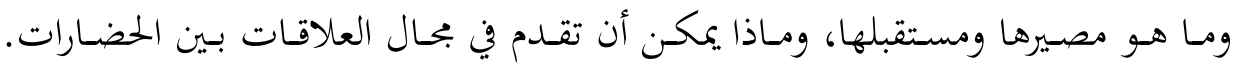

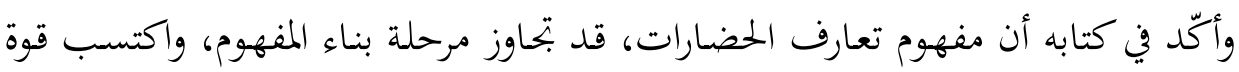

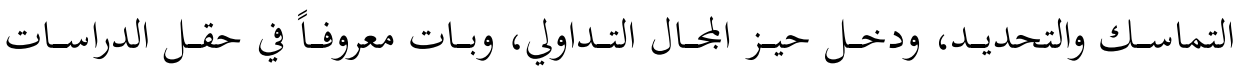

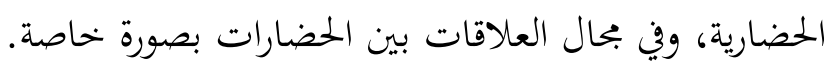

وتُعدّ نظرية تعارف الحضارات ردّاً معرفياً على نظريات صراع الحضارات، التي مثّلها

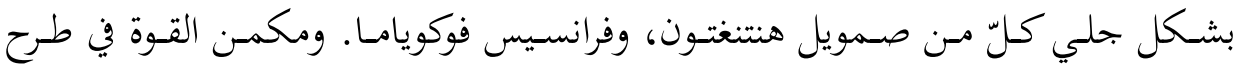

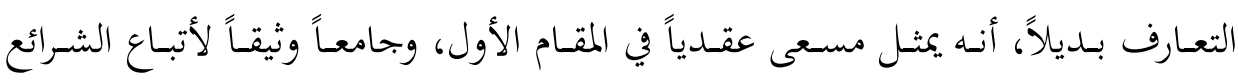

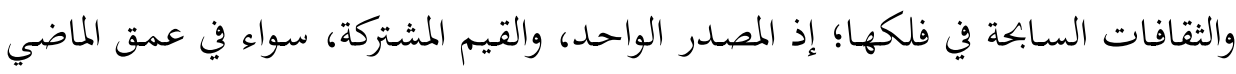

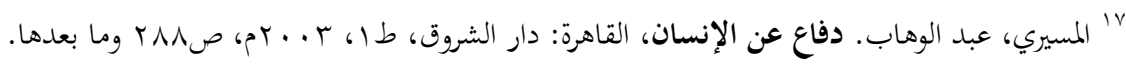


وجـذور التشكل الابتدائي، أو الحاجـة الحالية إلى قيم الدين حافظةً للبشرية، بعد فشل الأنظمة الشمولية المستمدة من النظريات الفلسفية المختلفة والمتضادة في أحيان كثيرة.

وقد استُبط المصطلح الوارد بمحتواه الدلالي، مـ القرآن الكريم، في الآية التي جـاء

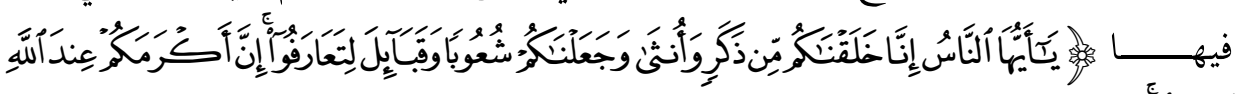

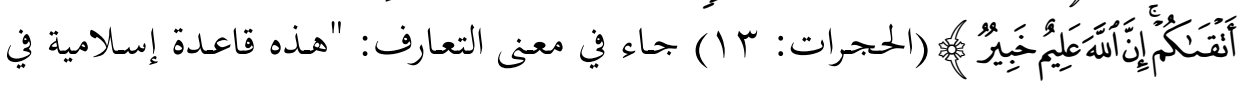
النظرة العامة إلى الناس على اختلاف ألواهم وقومياهم وخصوصياتم العائلية والجغرافية، فهي في الوقت الذي تؤكد فيه التنوع في الخصوصيات العرقية واللغوية، والنسبية الجغرافية

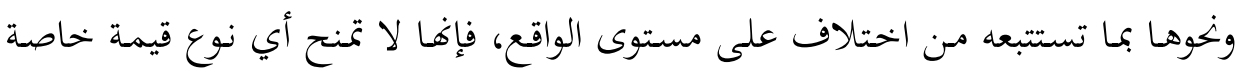

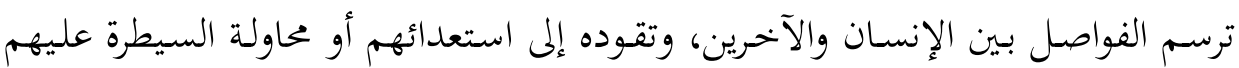

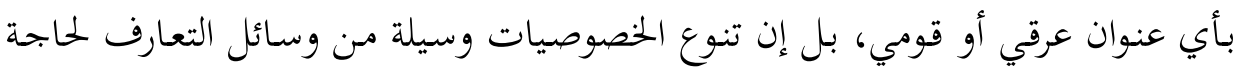

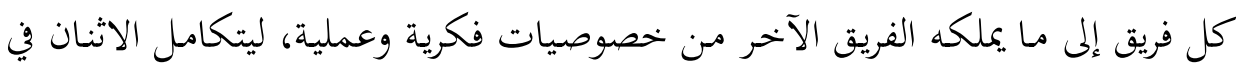

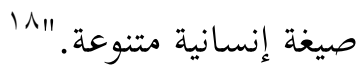

نفيد من النص السـابق، أن التعارف حالة تبـادل معرفي وتاريخي واجتماعي، وكوبي وعـالمي، يتأسـس على توافقـات نفسـية، والتزامـات مبدئيـة، وقيميـة، تفضي إلى الإقرار

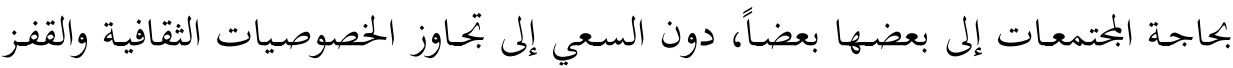

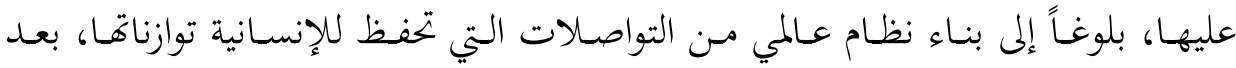

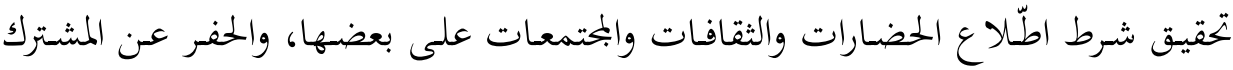

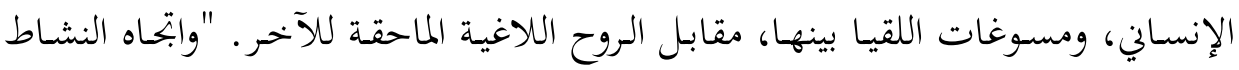

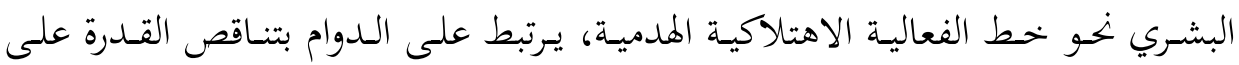

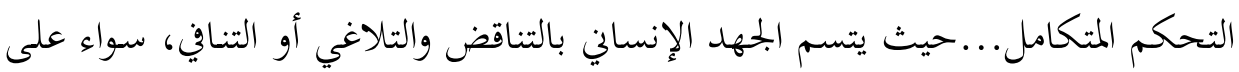

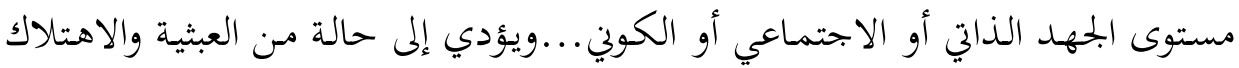

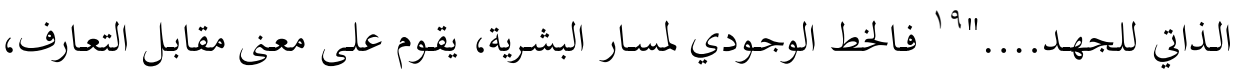

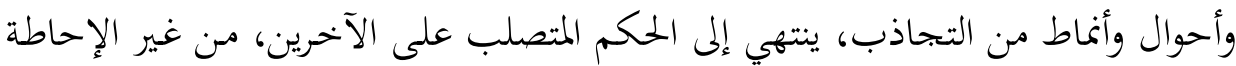

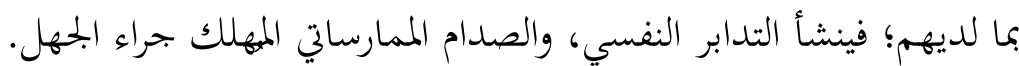

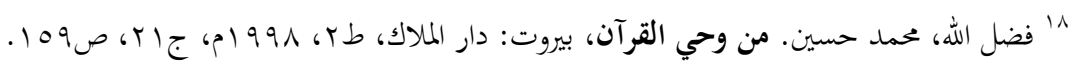

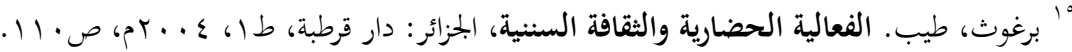




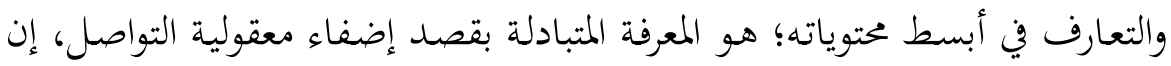

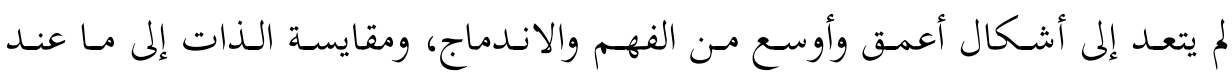

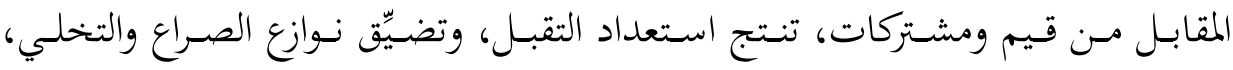

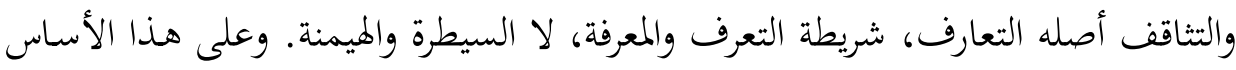

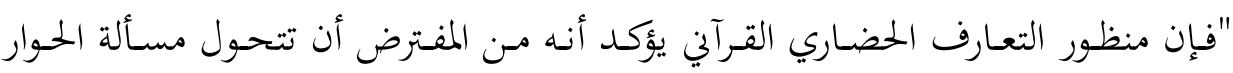

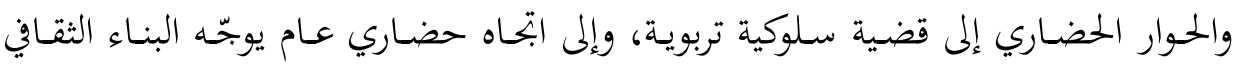

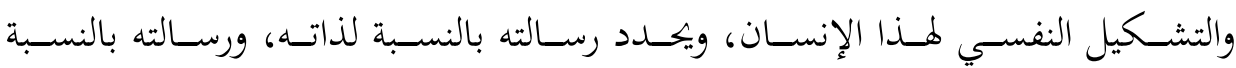

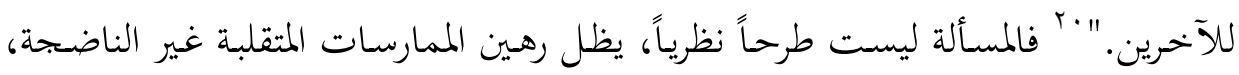

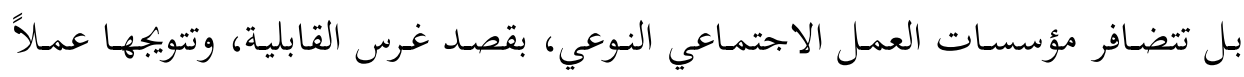

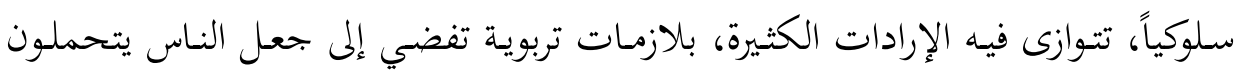

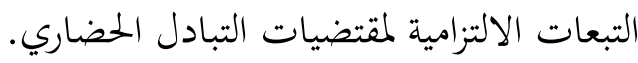

ويورد المفكر الحـداثي عبد الله الغذامي معنى إضـافياً للتعارف، بقوله: "إن مفهوم

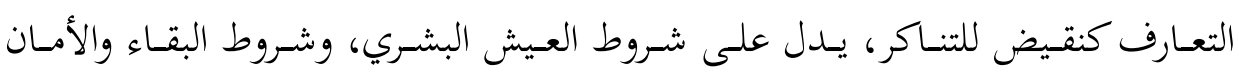

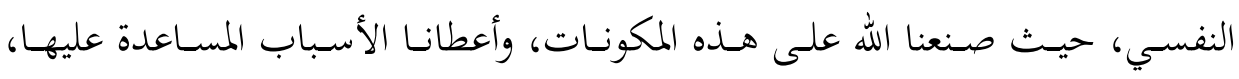

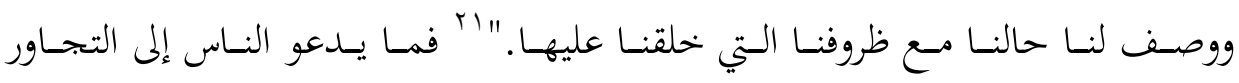

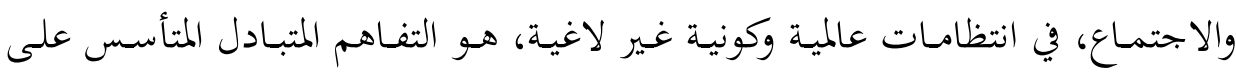

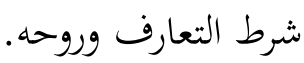

\section{ثانياً: مسلوبية الاحتواء}

لأن الاعتبار التاريخي الحديث والمعاصر، في غالبه يشير إلى غلبة النظرة الاحتكارية

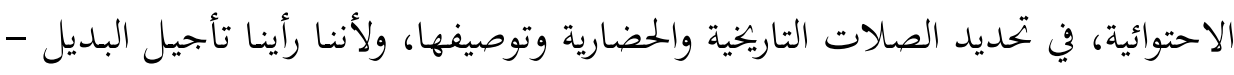

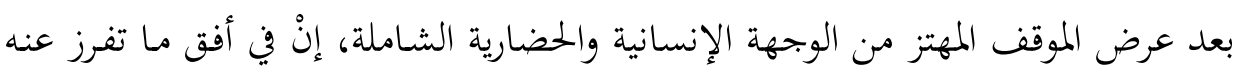
ب' برغوث، عبد العزيز . "التجديد الحضاري والحاجة إلى المنظور الاستخلافي وثقافة التعارف الحضاري"، بيروت: مجلة

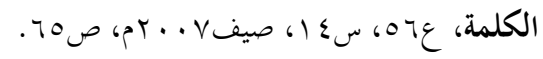

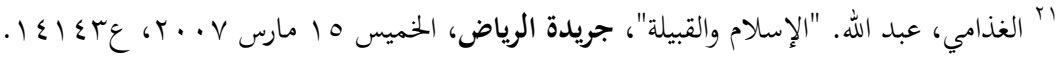


العلاقات الدولية، أو على مستوى المآل العام، الذي سينحسر رداء التاريخ عنه- فإنا

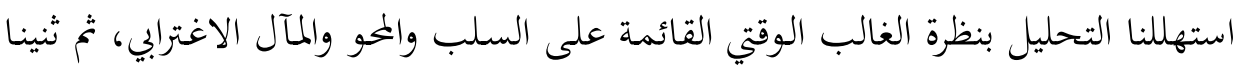

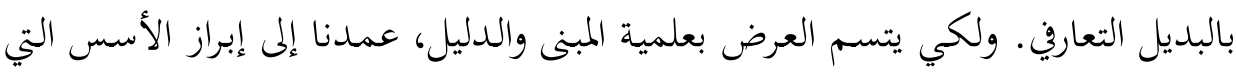

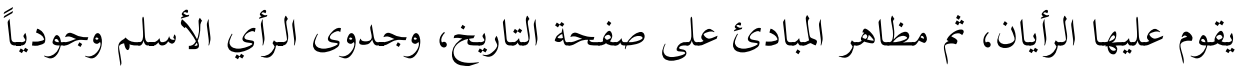
وحضارياً.

\section{1 ا منابت المسلوبية ومكونات الاحتواء:}

الوجه الأول للعلاقات الثقافية، أو للثناقف القائم على التغذية الامتصاصية، مبعثه

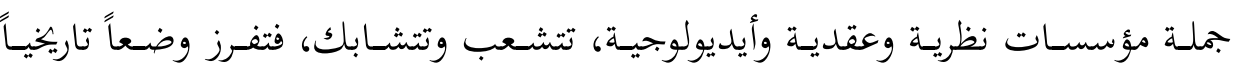
ونفسياً، خلاصته الاحتواء والمسلوبية؛ أي عقيدة مبعثها، تصور للحيـاة بوجسه الانفراد

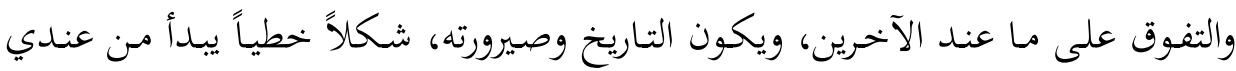

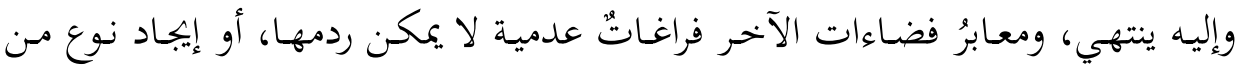

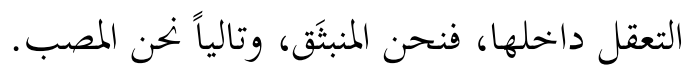

الفيلسوف الألماني المعاصر هانس جورج غادامير حينما أشار إلى أن الثقافة الغربية،

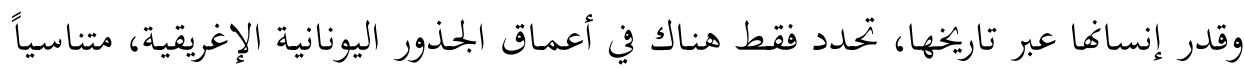

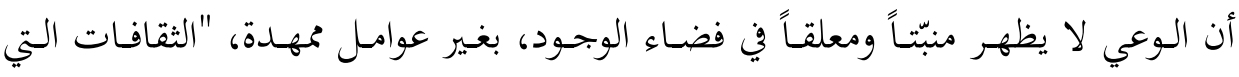

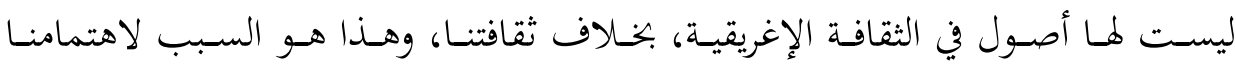

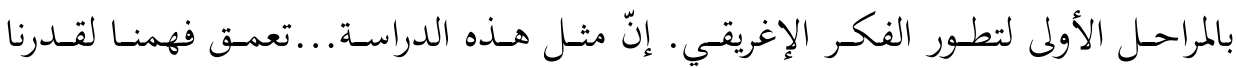

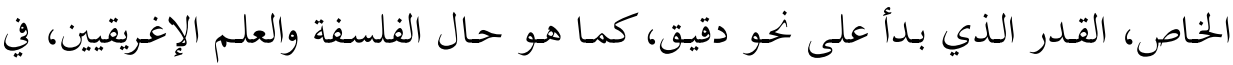

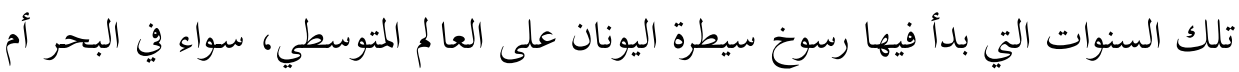

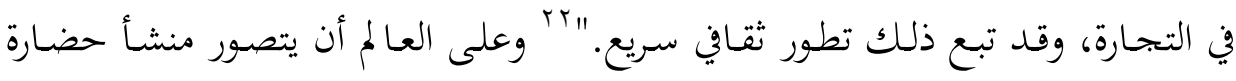

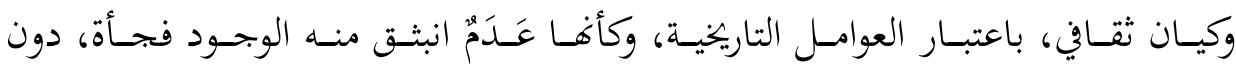

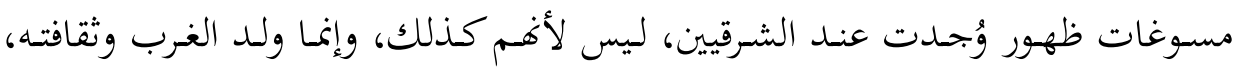

Tr غادمير، هانز جورج. بداية الفلسفة، ترجمة: علي حاكم صالخ، وحسن ناظم، ليبيا: دار الكتاب الجديد، طا، 
بتفـاعلات تلاقحيـة، وهـذا مـن مولـات التـابر الثتـافي المفضي إلى حـالات الاستلاب والمسلوبية، فيمتنع الحوار والتثاقف.

ورُبَّ قائل يقول، مـا ذنب المصب، إذا تكوّن الثقافة جـاء على هـا النحو ابتـاءًٌ

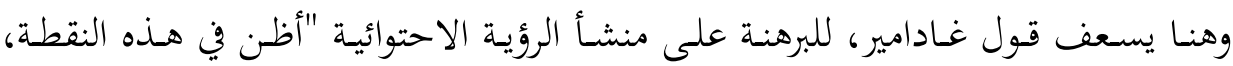

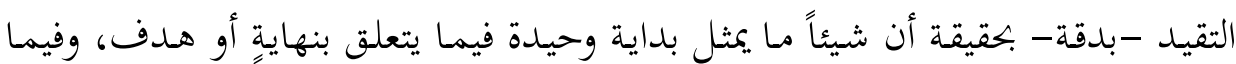

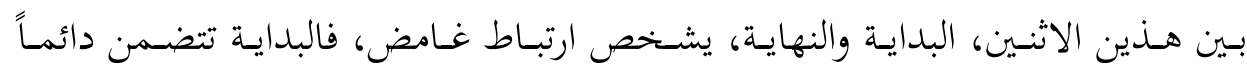

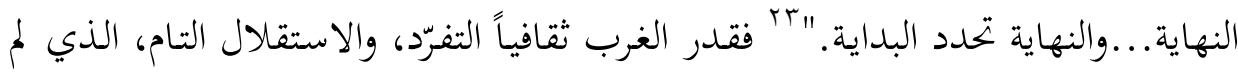

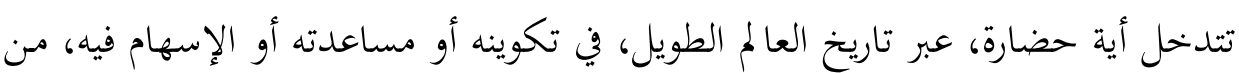
أي نوع كان!

ولكي يتمكن الغرب ثقافياً من الانكفاء على الذات، والانغلاق في بوتقة الموروث

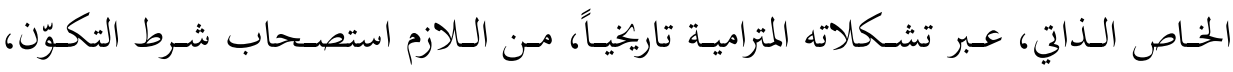

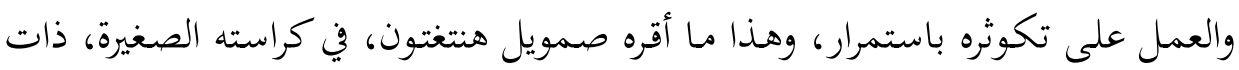

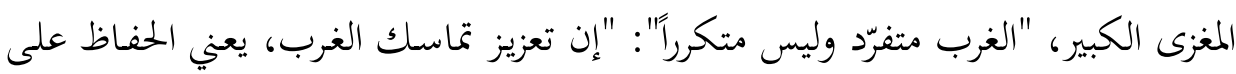

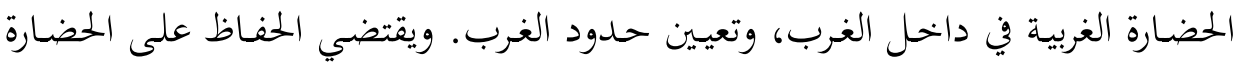

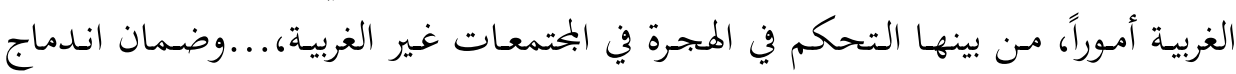

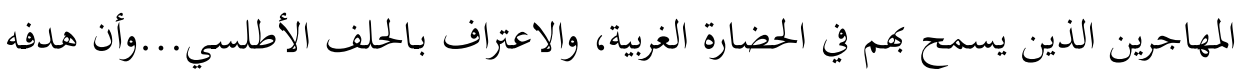

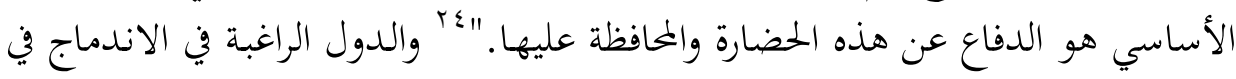

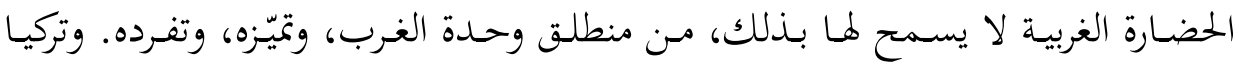

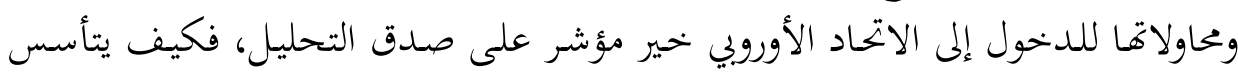

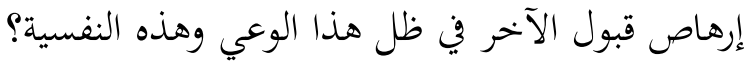

\section{Y. الانكفاء على الذات، والتوجس من الآخر :}

وما يُرْبِي التحليل السالف، ما قاله الفيلسوف الفرنسي المعاصر، روجيه غارودي، في

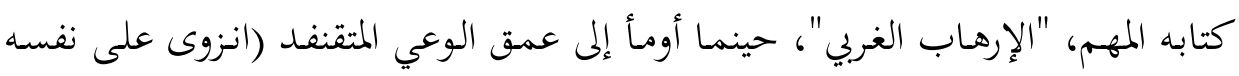

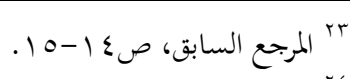

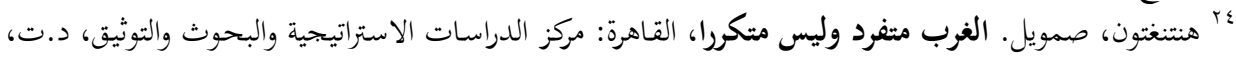


كفعل القنفد) على الذات، وجذوره التاريخية العميقة؛ إذ "طريق الهيمنة الذي أخذذ اليوم

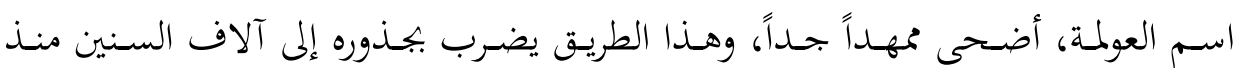

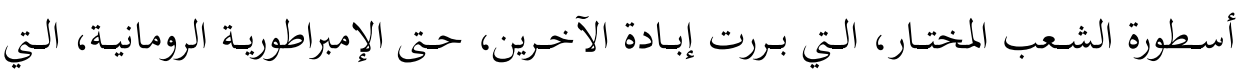

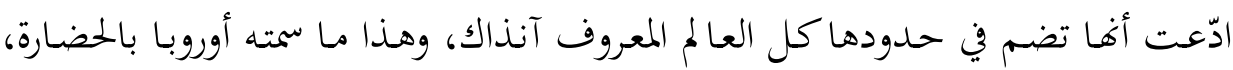

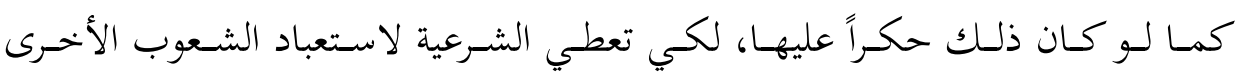
واستعمارها، أما قادة الولايات المتحدة الأمريكية، فقد جعلوا مهمتهم -التي كلفهم بها

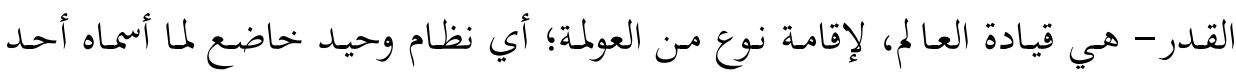

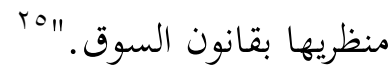

فمنطق الأفضلية، والاصطفاء الحصري، لخصوصيات عرقيـة وثقافية، لازمـٌُّ للوعي

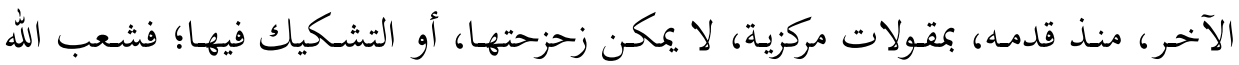

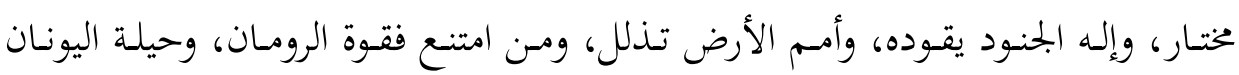

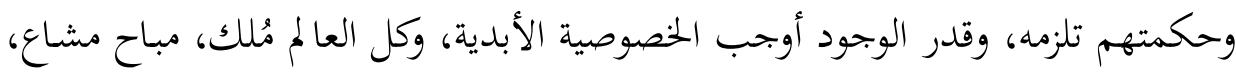

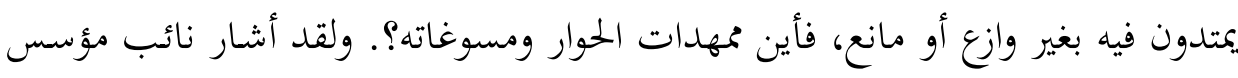

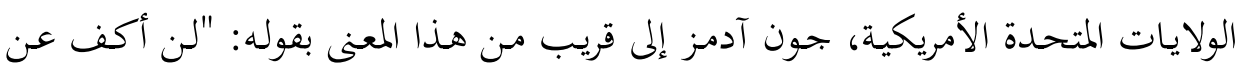

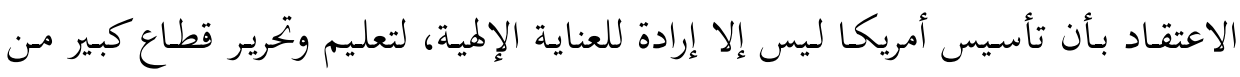

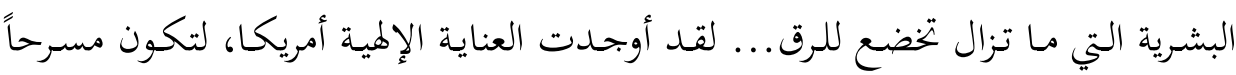

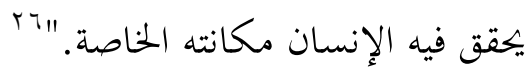

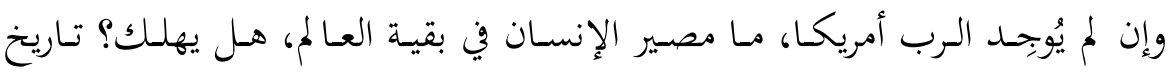

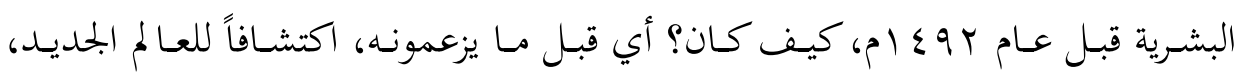

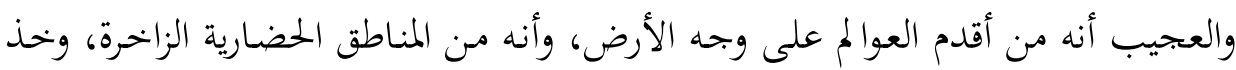

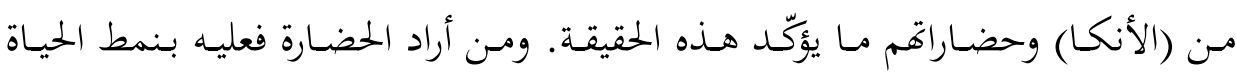

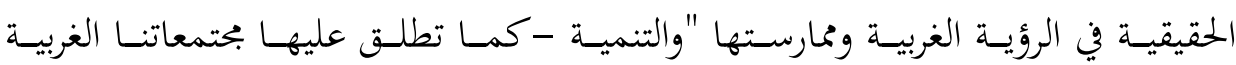

• غ غارودي، روجيه. الإرهاب الغربي، ترجمة: داليا الطوخي وآخرون، القاهرة: مكتبة الشروق الدولية، طا، جا، 


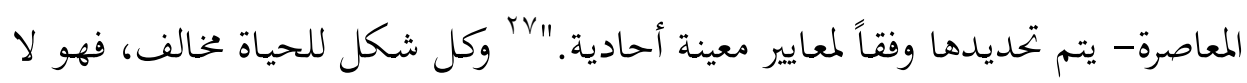

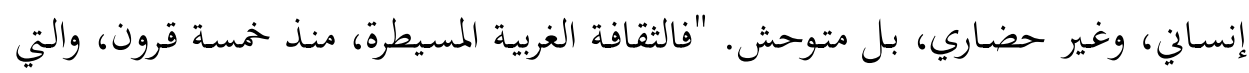

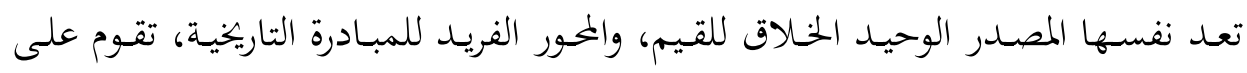

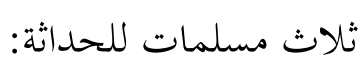

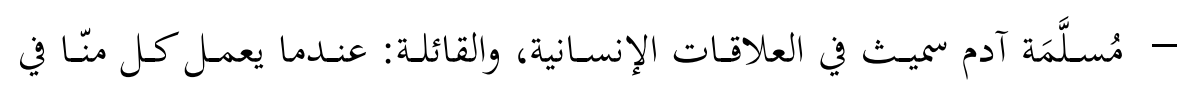
سبيل منفعته الخاصة، فهو بهذا يساهم في تحقيق المنفعة العامة. - مُسلَّمَة ديكارت في علاقتنا مع الوجود، التي تجعلنا أسياد الطبيعة ومُلكاك الوجود.

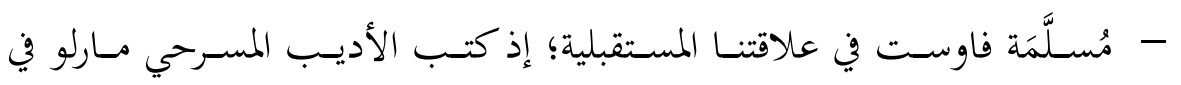

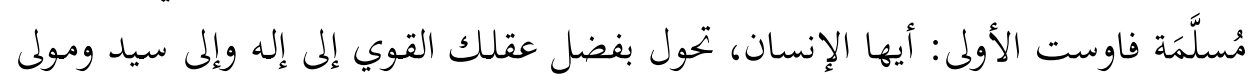

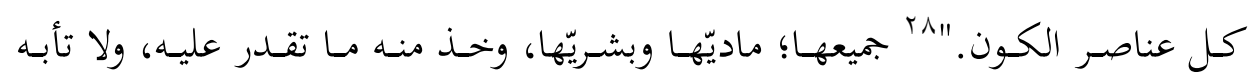

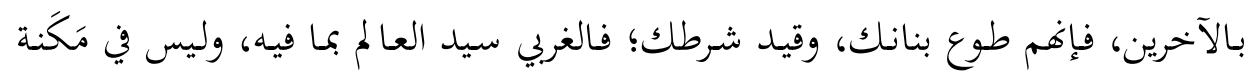

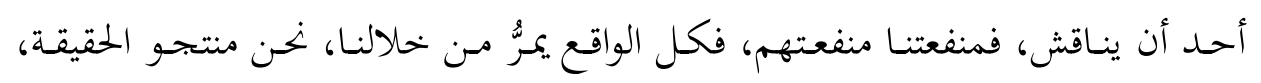

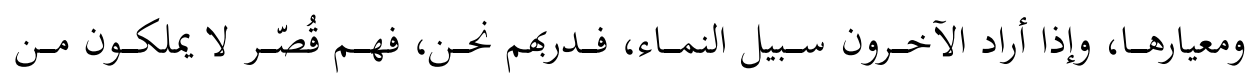

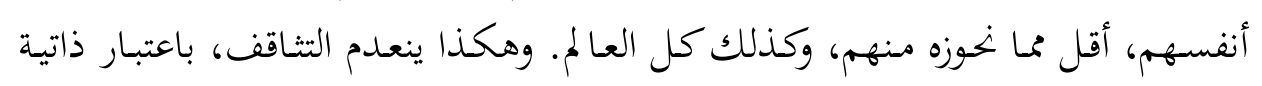
المنطلق والغاية.

\section{r. ازدواج المعايير، والمكاييل المائلة:}

التعامل مع قضايا الإنسانية برؤية تعمد إلى الاحتواء بناء على النظرة المميّزة، يؤكده

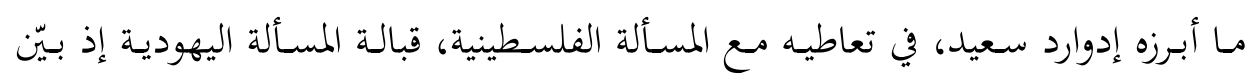

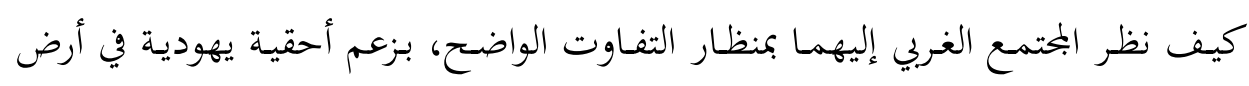

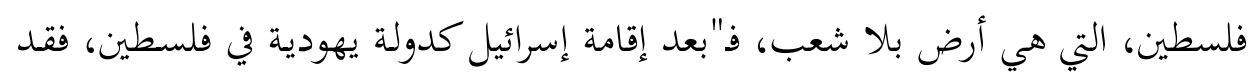

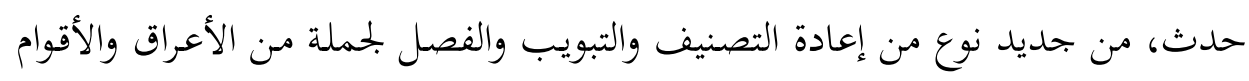

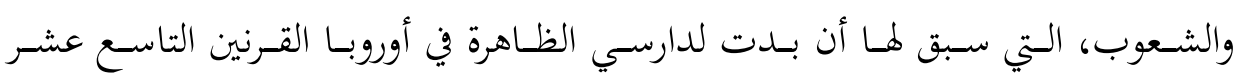


والعشرين، إعادة لعملية بحسيد سلسلة الانقسامات التي كانت فيما مضى ملأى بالدماء التهاء

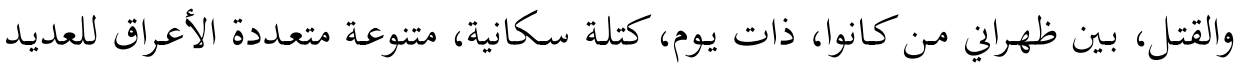

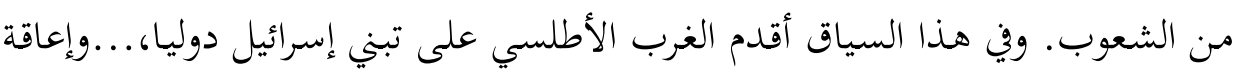

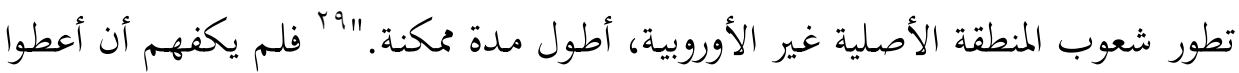

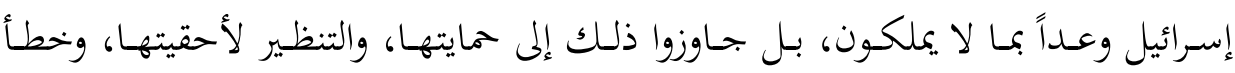

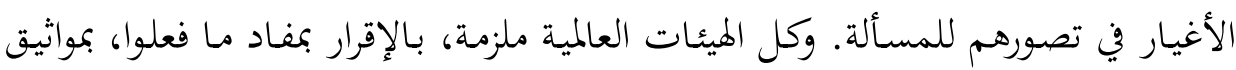

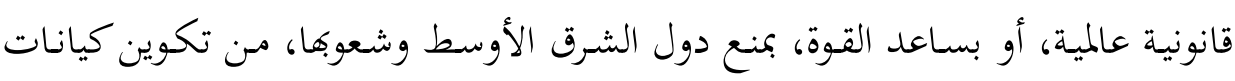

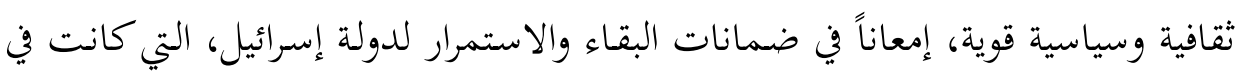

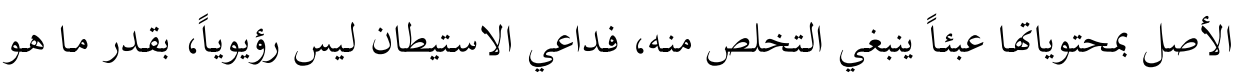
استراتيجي.

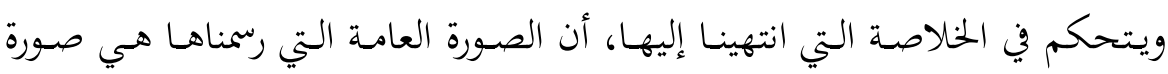

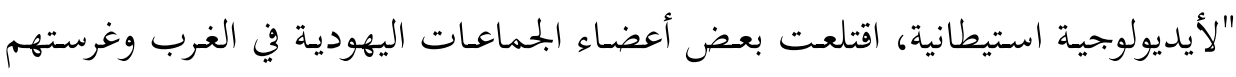

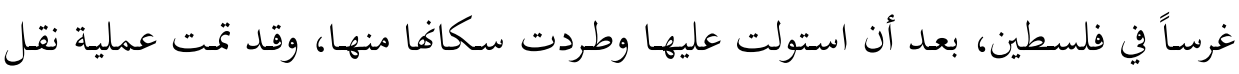

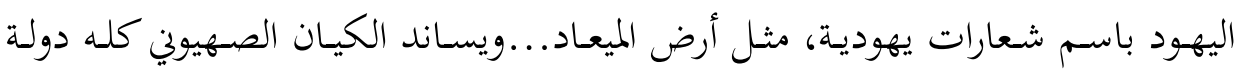

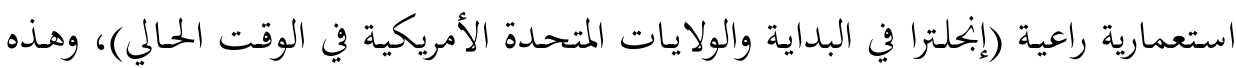

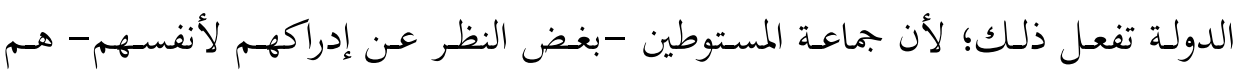

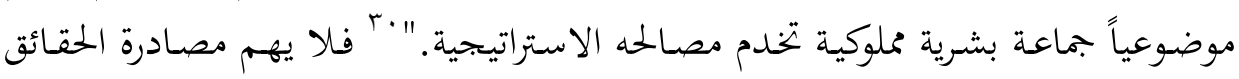

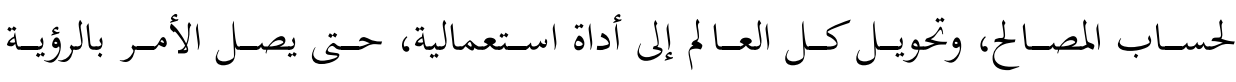

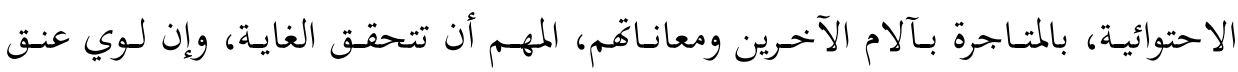

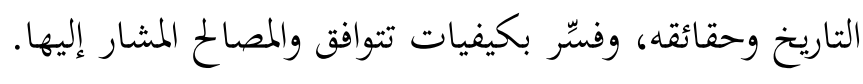

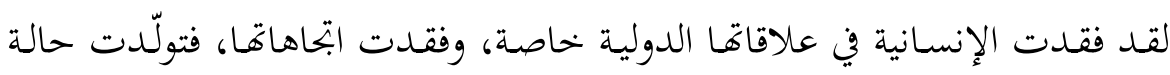

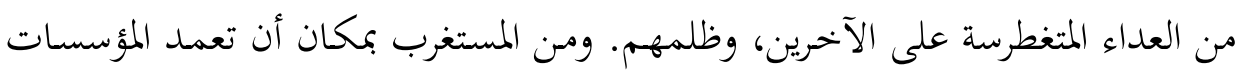

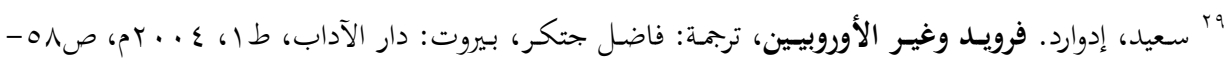

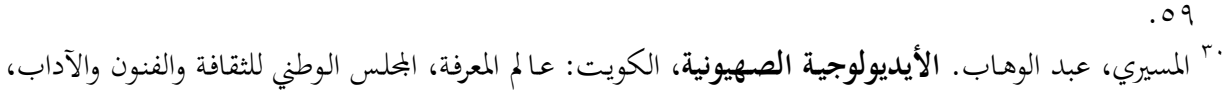




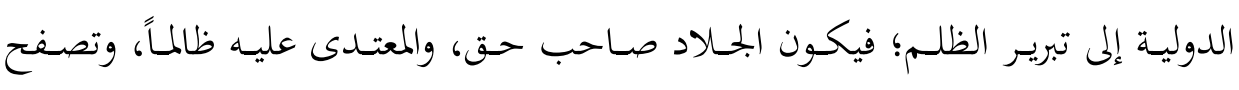
قرارات بحلس الأمن الدولي يؤَّد هذه الحقيقة.

ولا يكفي أن تظله المجتمعات الإنسانية، في دائرة حاجاتها البيولوجية البحتة، وإنما

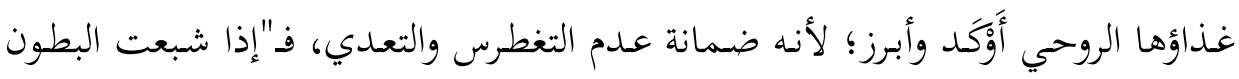

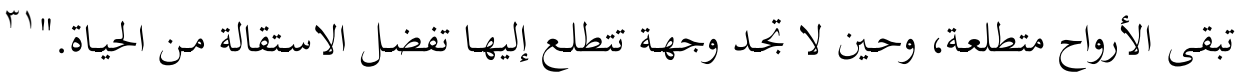

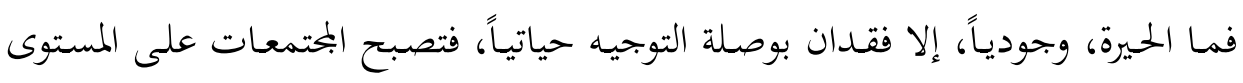

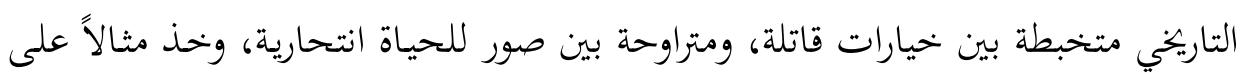

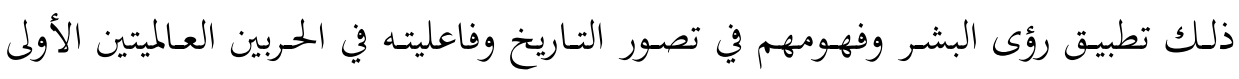

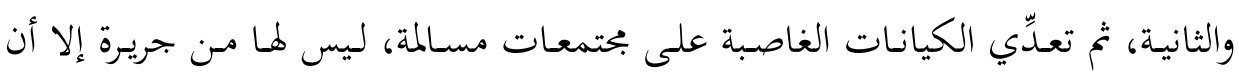

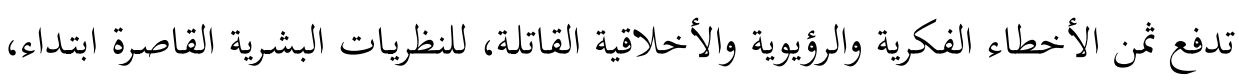
فما بالك في كوها ذات روح استغلالية استكبارية تالياً.

ونشير هنا إلى آراء بعض كبار فلاسفة الحضارة في الغرب، ومنهم الفيلسوف الألماني

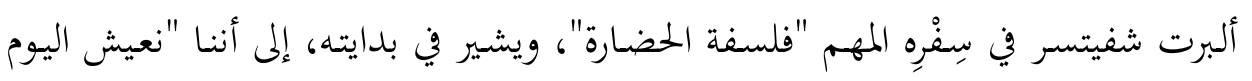

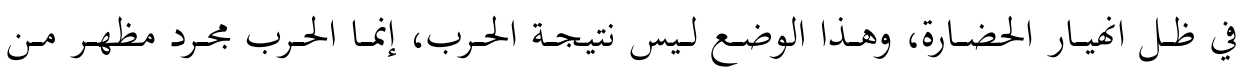

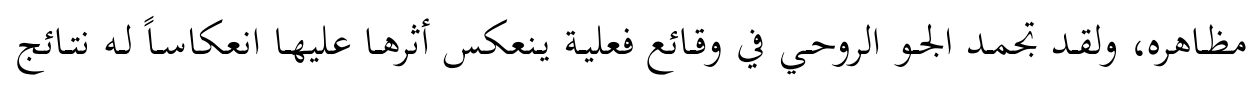

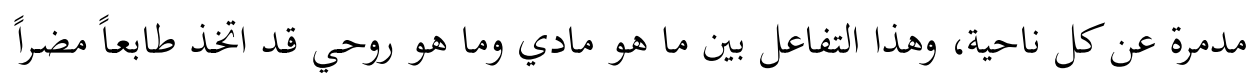

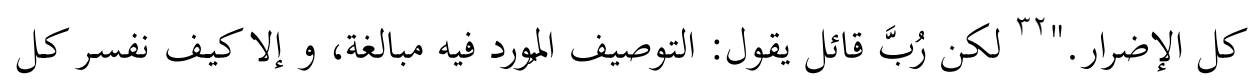

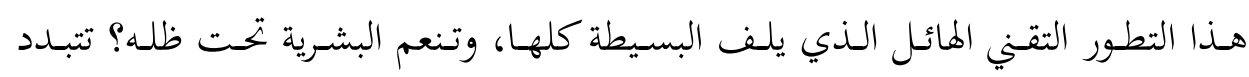

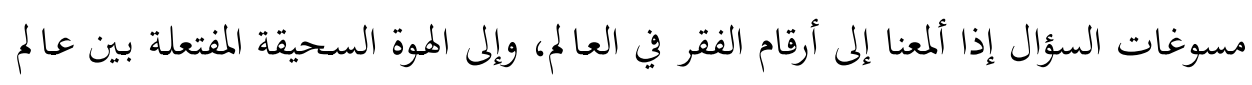

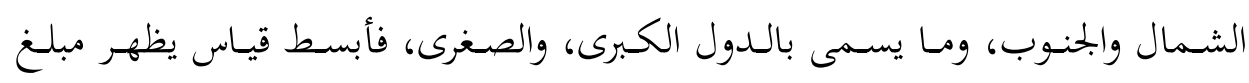

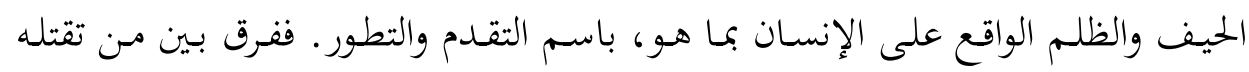

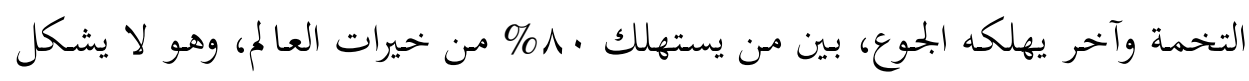

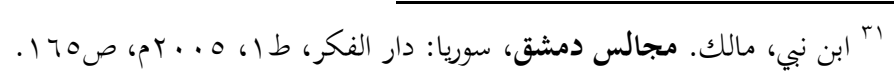

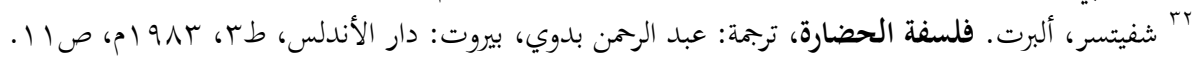




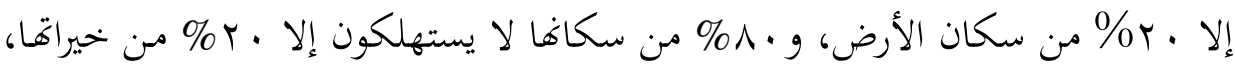

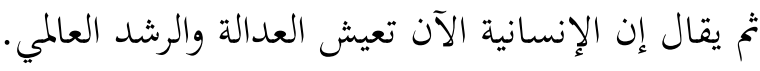

وفي موضع آخر يقول شفيتسر "من الواضح لكل ذي عينين أن الحضارة في سبيلها

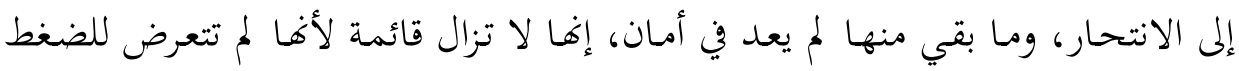

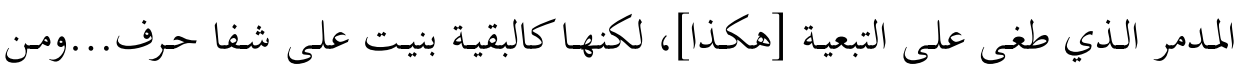

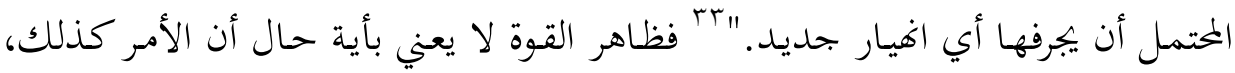
فلم يسقط الاتحاد السوفياتي إلا بعد أن بلغ أوج قوته.

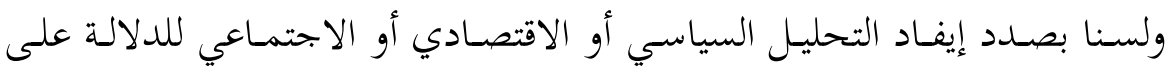

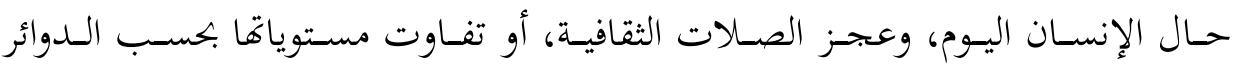

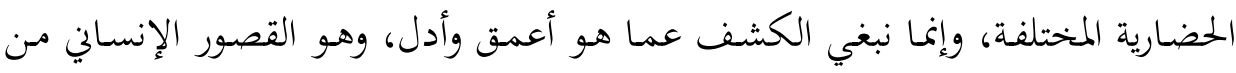

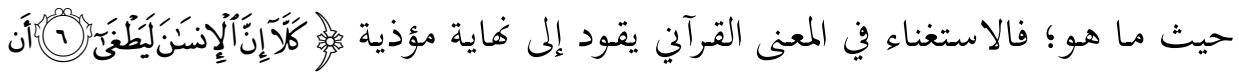
(العلقَ

وعندما استغل الإنسان طاقاته الذاتية بعيداً عن الحماية الفوقانية المتجاوزة، انتهى به

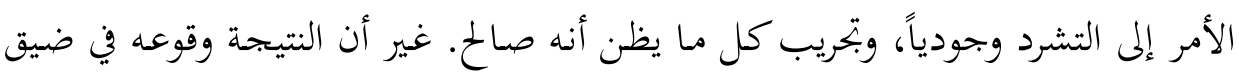

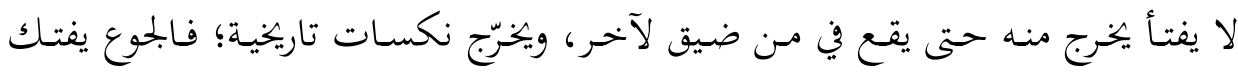

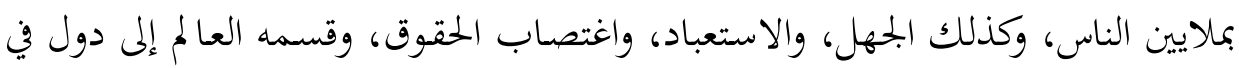

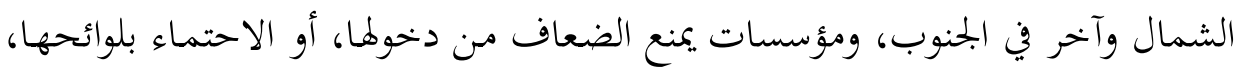

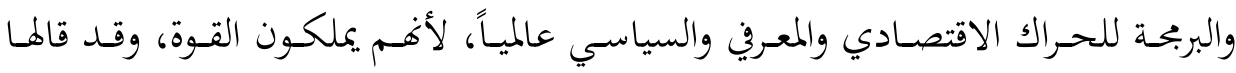

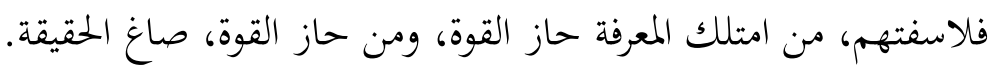

\section{ع. ثقافة الإمبراطورية، وضمور الوازع الإنساني الكوني:}

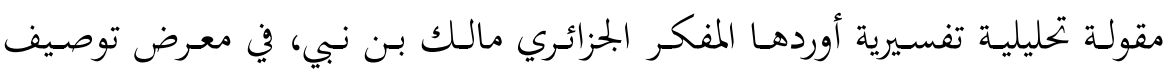

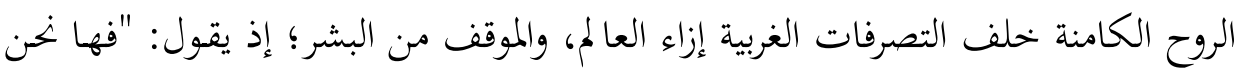




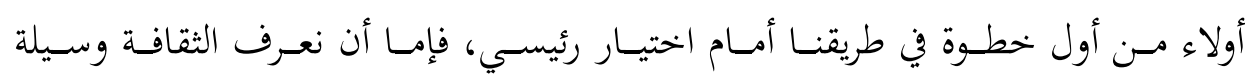

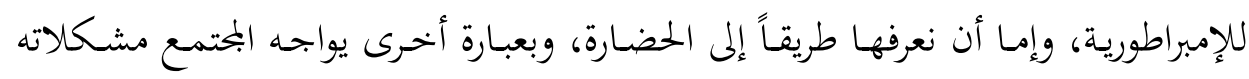

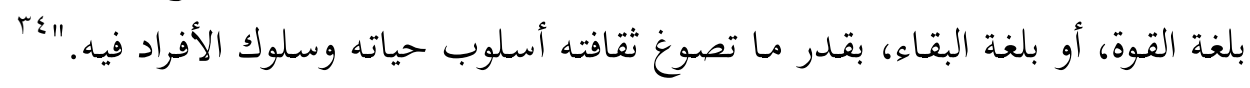

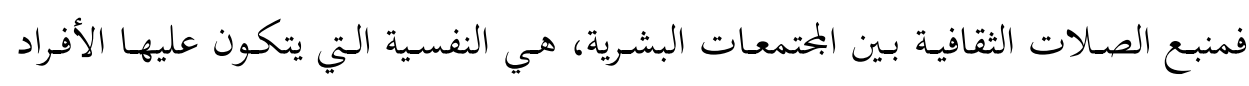

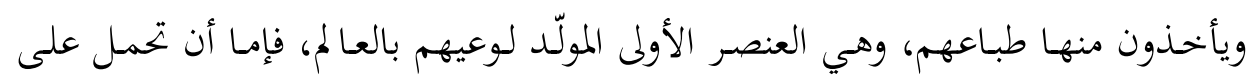

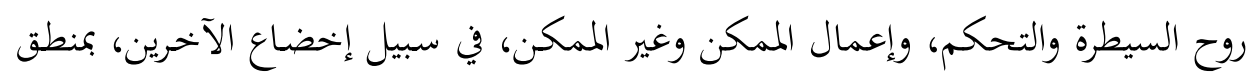

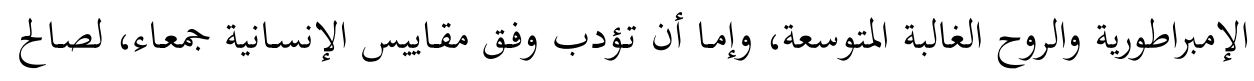
الإنسان.

وبحكـم الاحتكـاك الثقافي بينتا وبين الغرب المعاصر -وفي مقدمتـه أوروبـا- فإننـا

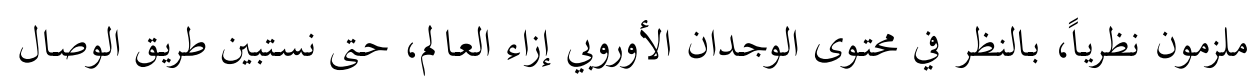

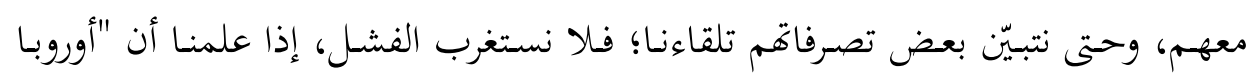

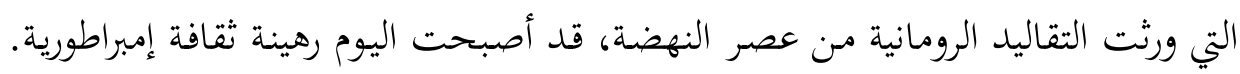

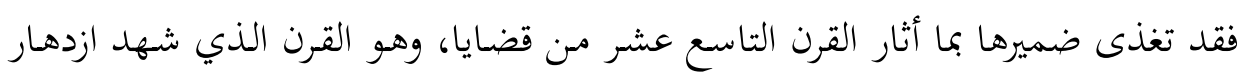

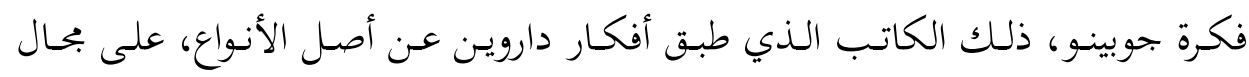

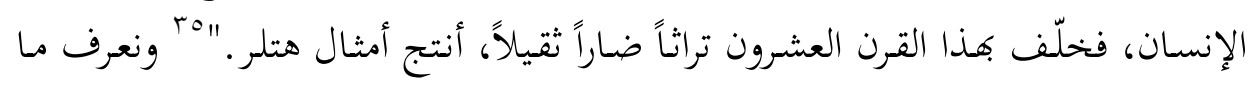

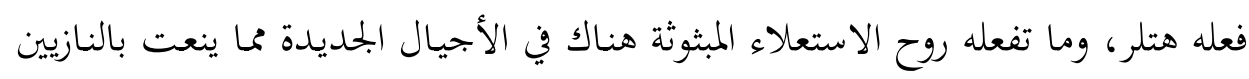

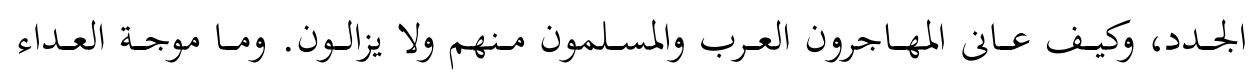

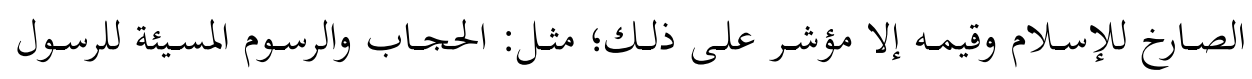

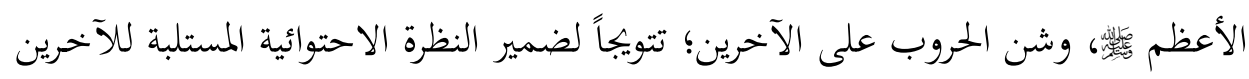

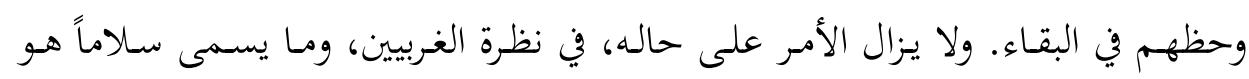

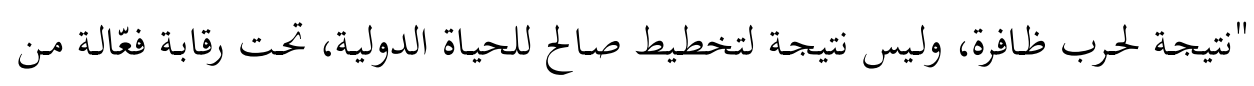

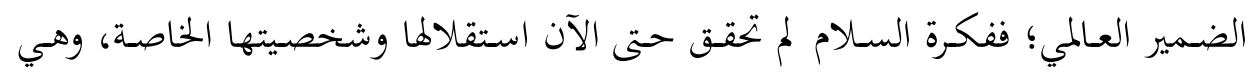
تدين في خضوعها هذه للثقافة الإمبراطورية، التي لا ترى السلام إلا حيثما يكون المان مؤيداً

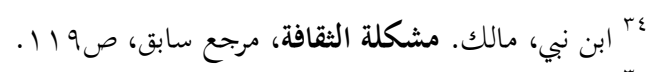
ro 


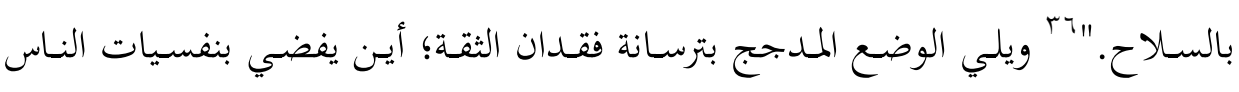

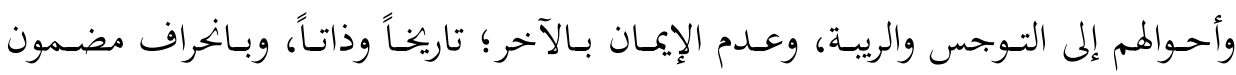

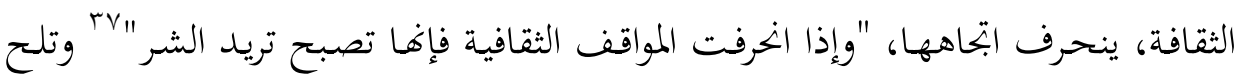

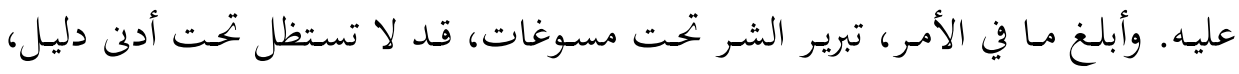

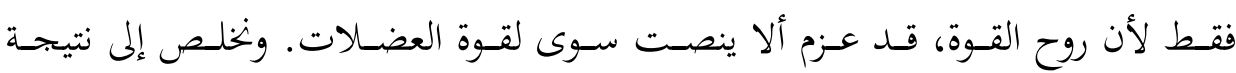

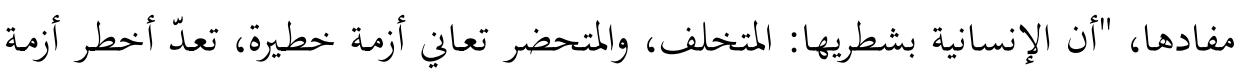

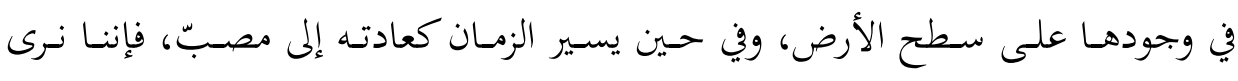

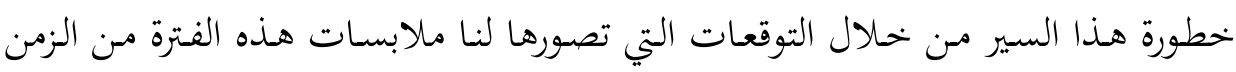

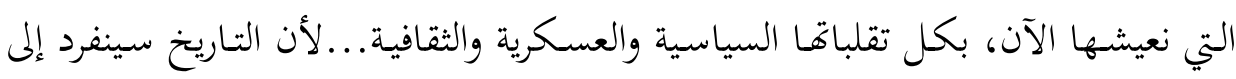

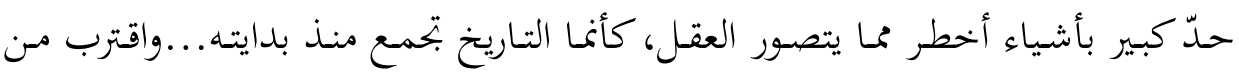

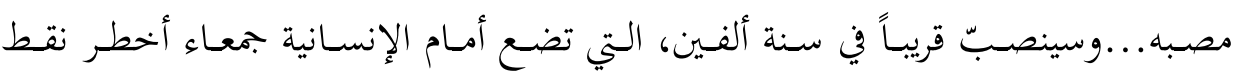

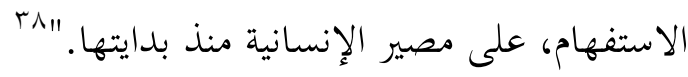

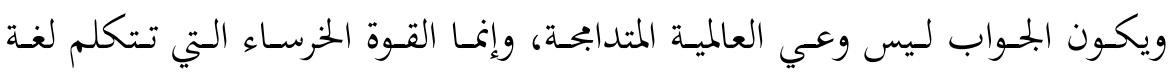

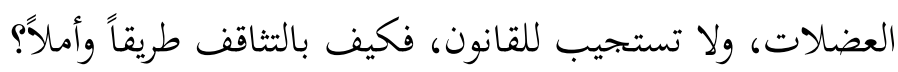

\section{ه. (عولمة الذات وتنميط الآخر:}

من أخطر موانع التثاقف، فكرة العولمة ذاتما، بخاصة إذا فهمنا العولمة بوصفها تعميماً

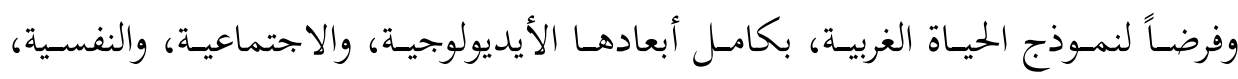

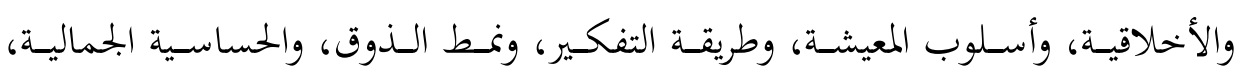

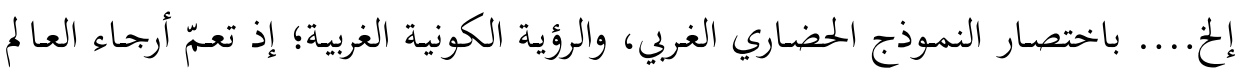

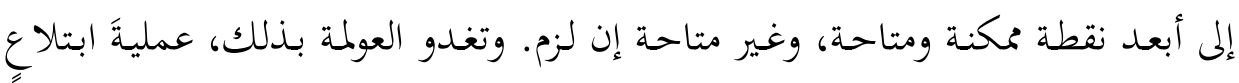

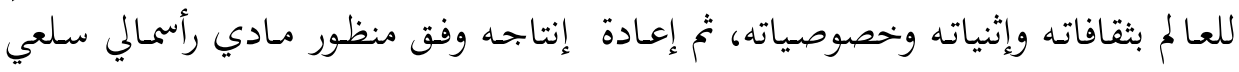

$$
\begin{aligned}
& \text { شيئي. }
\end{aligned}
$$

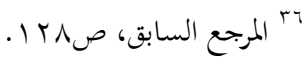

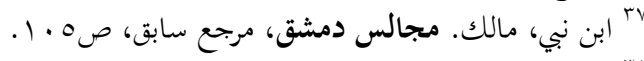

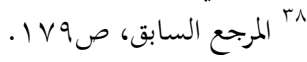




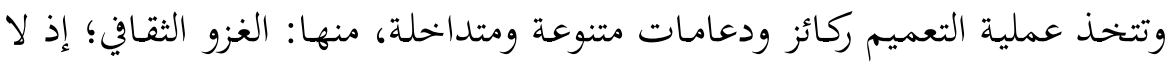

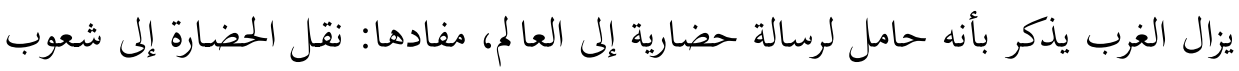

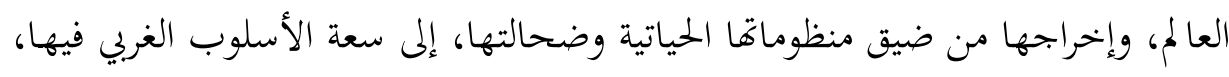
وهكذا كانت دعوى الاستعمار والتنصير والاستشراق، ودعوى العولمة الآن.

لا خحلاف في مـا سبق توصيفه، مـن تأكيد الغرب على أزلية تفوق الثقافة الغربية

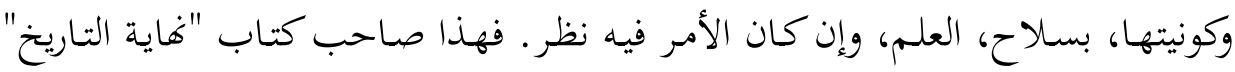

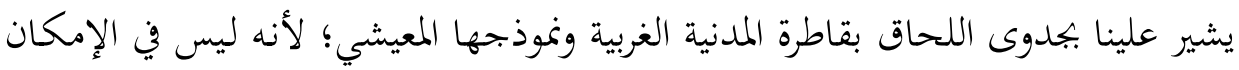

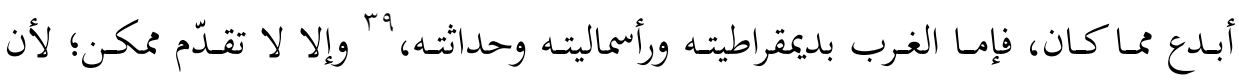

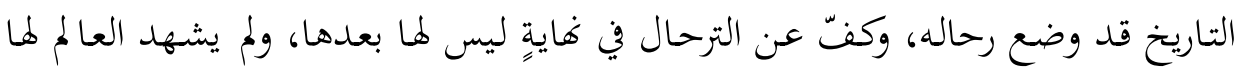

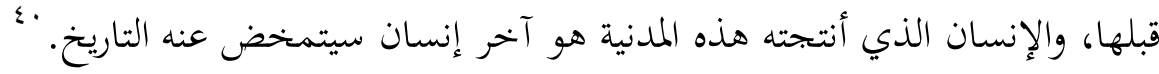
إضافة إلى الترويج لعالمية الثقافة الغربية، والإلماح إلى إنسانيتها وحضاريتها، وأها نتاج

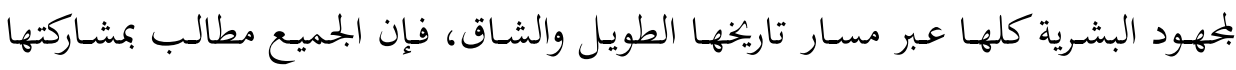

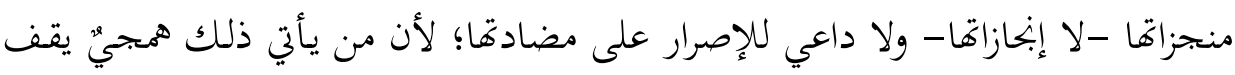

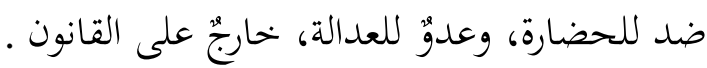

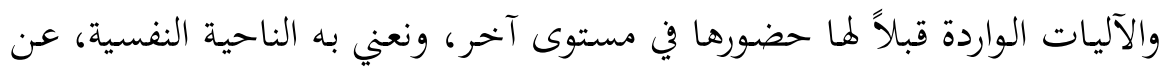

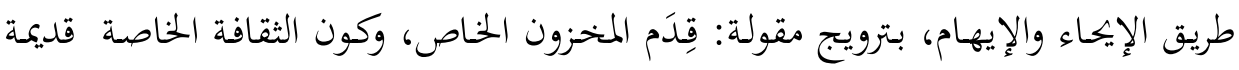

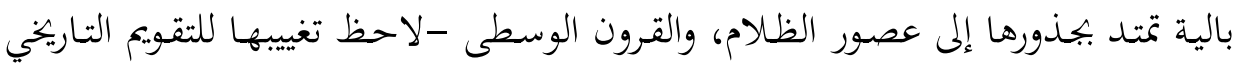

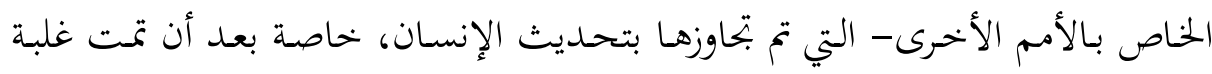

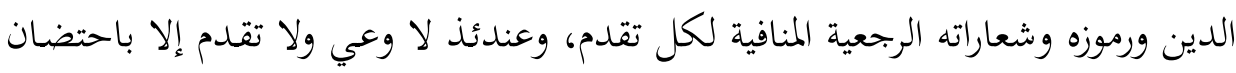
الثقافة العالمية، التي لا بديل عنها، والتنكر للخصوصية الثعافية الثقافية التي هي ضدم، وعندئ الإنسانية. وتعتمد العولمة أيضاً على القوة العسكرية والسياسية والاقتصادية، وقبلها وأخطرها

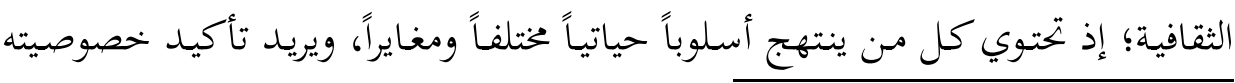

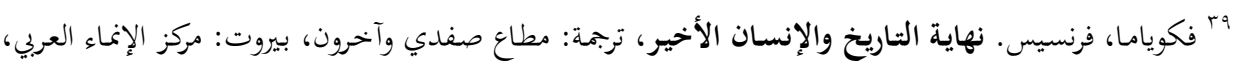




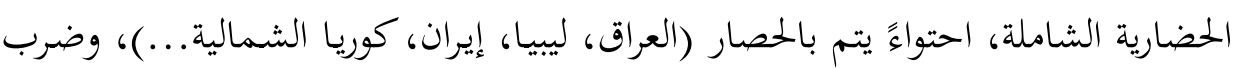

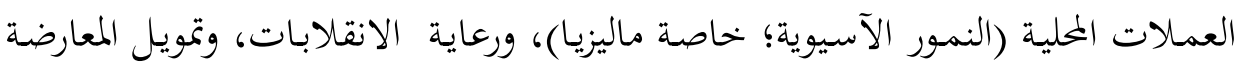

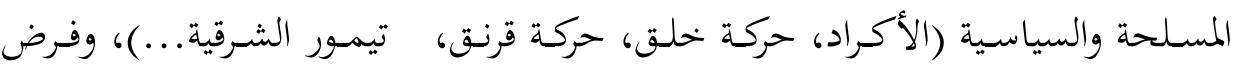

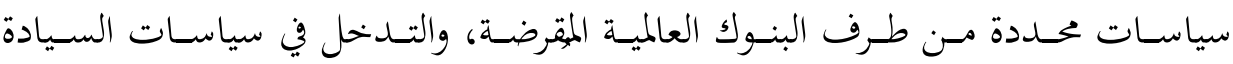

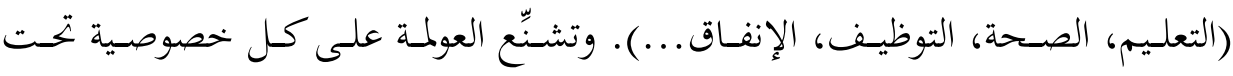

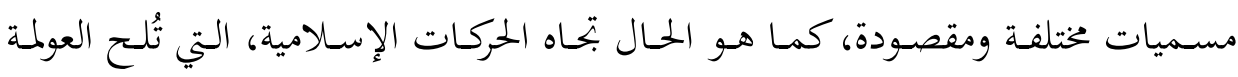

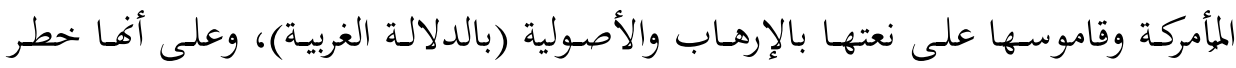

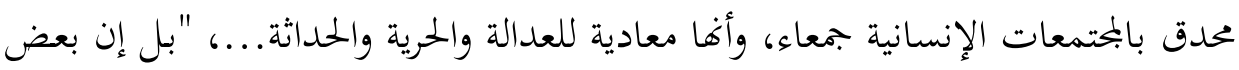

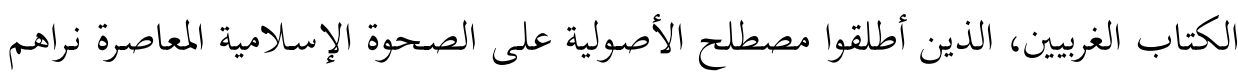

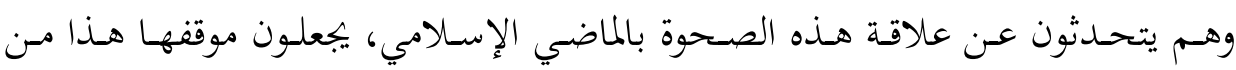

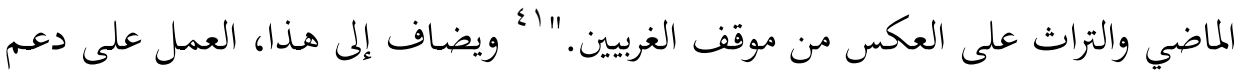

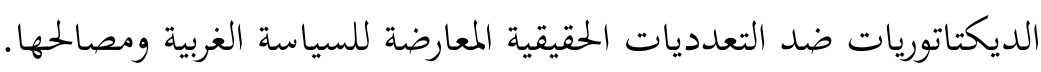

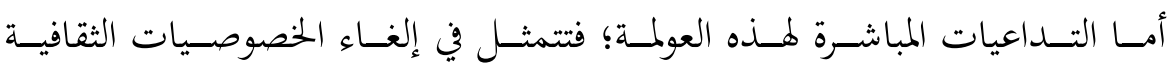

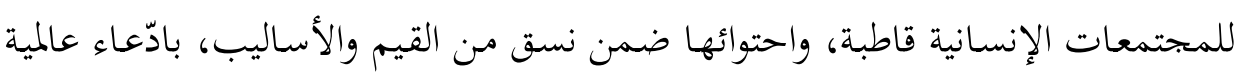

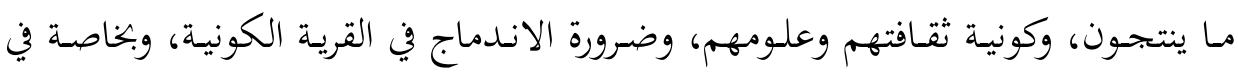

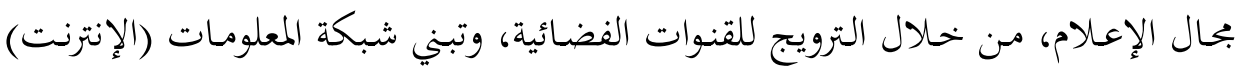

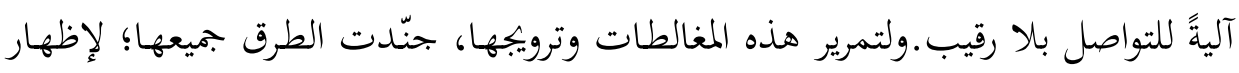

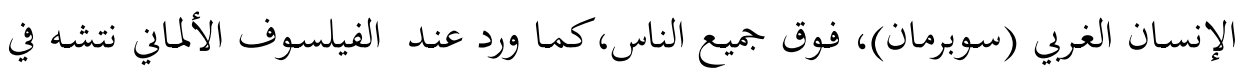

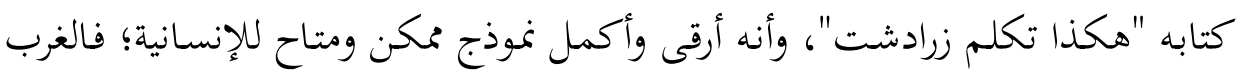

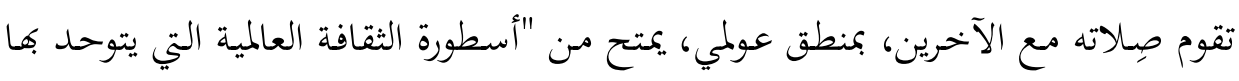

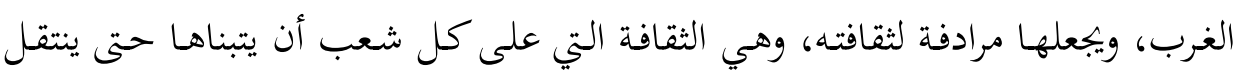

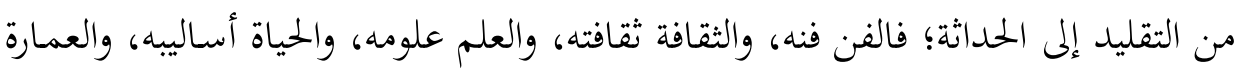

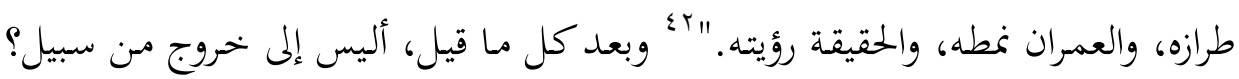

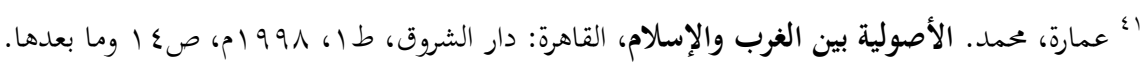

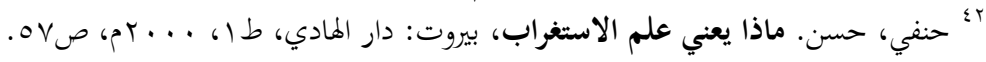




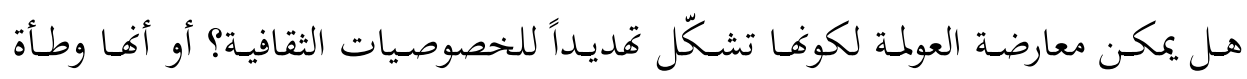

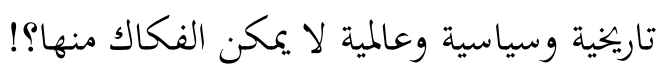

\section{ثالثاً: معقولية التعارف}

\section{I ـ المُوَسسسَات النظرية والعقدية للرؤية التعارفية:}

مِن ادعى الأمور التي يجب العمل على أساسها ومن خلالها، الترويج لفكرة تنوع

البشر، وغنى بتحارهم التاريخية، وأنه من غير المقبول قولبتهم في أشكال جاهزة وتامة؛ لأن الأصل الوجودي فيهم -أي البشر - هو التنوع والتعدد في إطار من التفرد الذي لا ينفي

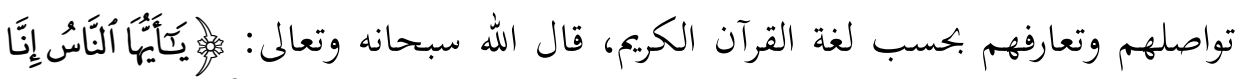

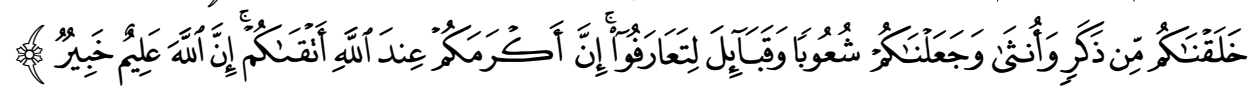

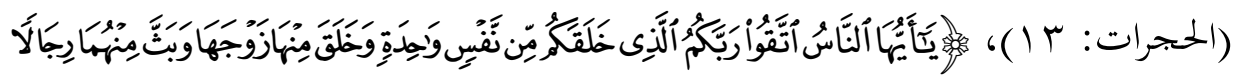

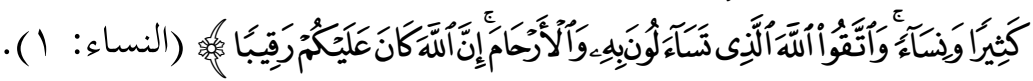

فمـع اخـتلاف النـاس ووجـودهم مـن فجـر التـاريخ في بتمعـات، وهـم يتبـاينون في

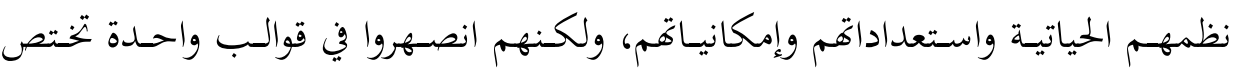
بمناطقهم ومدى بحاوبهم معها. واستمر التعارف بينهم، و ونقل بعضهم إلى بعض خهبرته

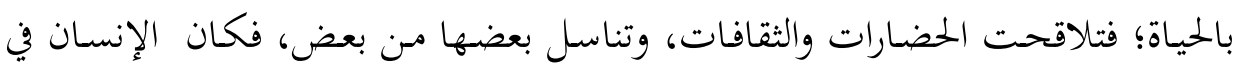

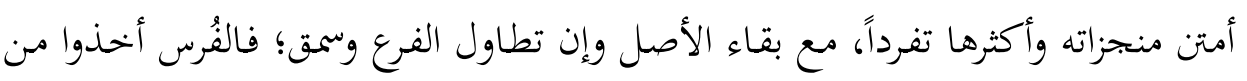

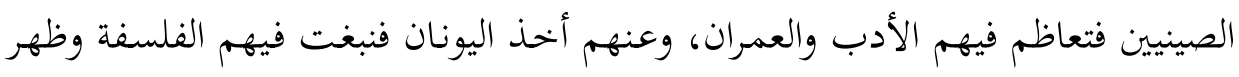
فيهم عظماء العقل ومبدعو المنطق، وعنهم اقتبس الرومان فشادوا العقل قوة، والمنطق

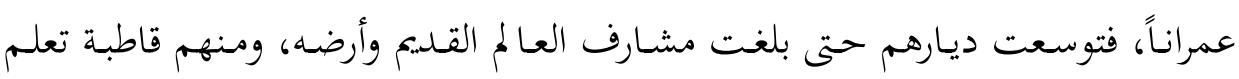
المسلمون، ومزجوا ما أخذوا بما أسسوا تفرداً بوحي من القرآن والسنة، فظهر أغزر إنتاج

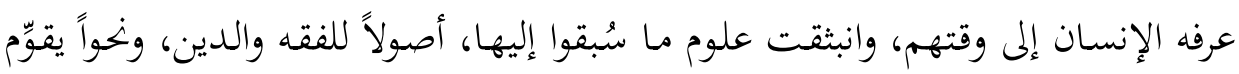
اللسان. ولم تنكر أمة على غيرها ما هي فيه، بل سعت إلى التعلم منها، والاستزادة، حتى ولى

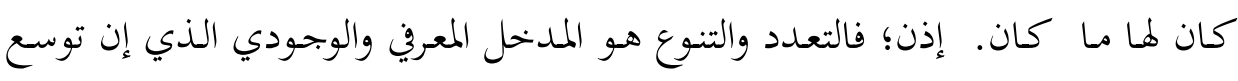




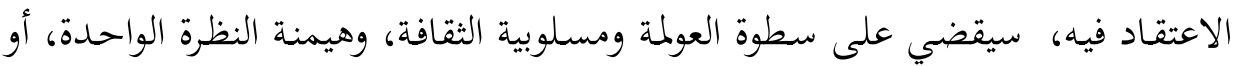
سيحولها إلى عالمية تنضوي البشرية جمعاء تحت سقفيها. لمُ تَعُد خرافة كونية ما يصنعه الغرب تنطلي على ذي بال، فالعاً لم وإن أخذا من

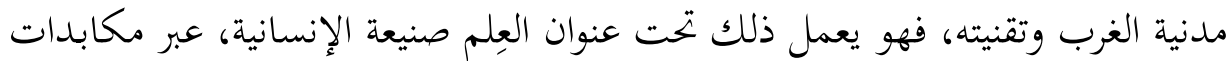

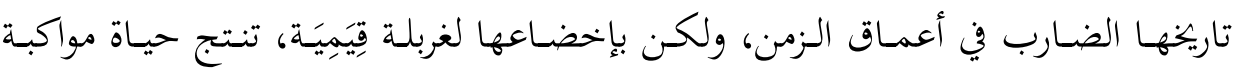

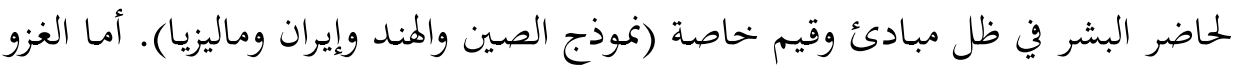

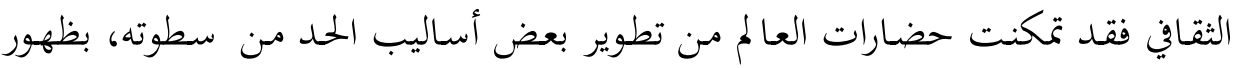

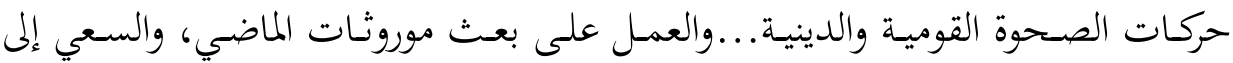

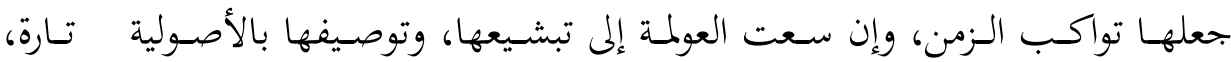

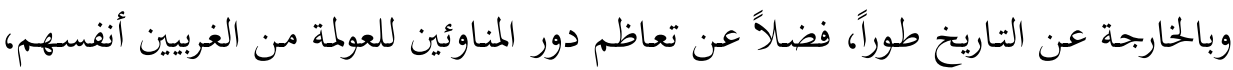
خاصة أن وتيرة حوار المثقفين والعلماء تزداد بين الفينة والأخرى. وهكذا يتكامل عقداء

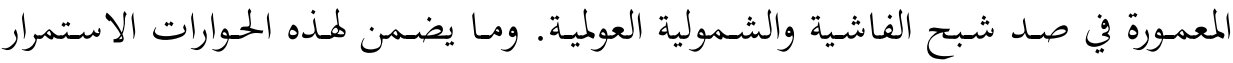

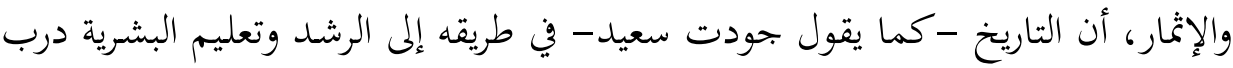

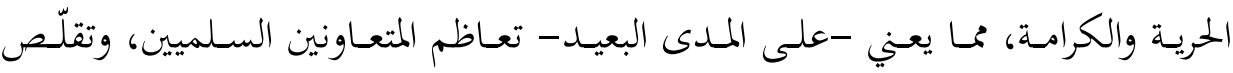

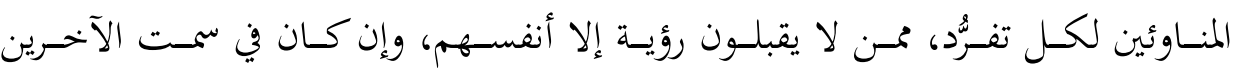

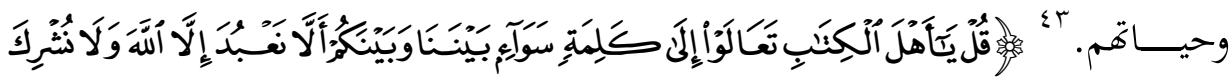

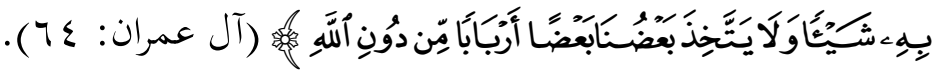
والتنوع حقيقة كونية مطلقة شاملة لكل الكائنات في عالمي الغيب والشهادة، دلالةً

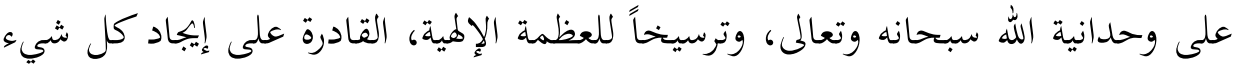

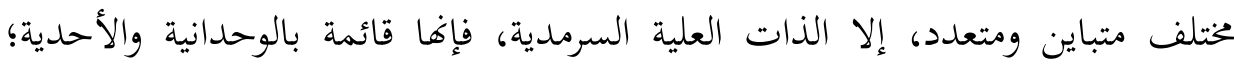

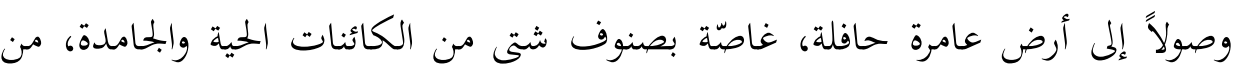
شجر، وحجر، وغر، وحيوان، ومن كينونات بشرية؛ سمراء، وبيضاء، وحمراء، وسوداء.

"r دواق، الحاج بن أمنه. من العولمة إلى العالمية، معارضة العولمة ممكنة وواجبة، موقع الشهاب الثقافي، :

http://www.chihab.net/modules.php?name=News\&file=article\&sid=1807 


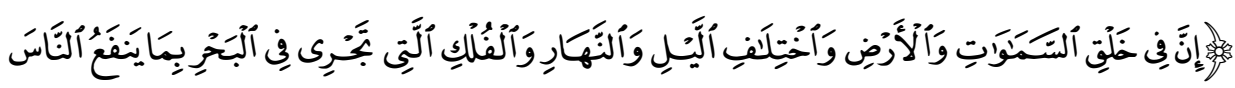

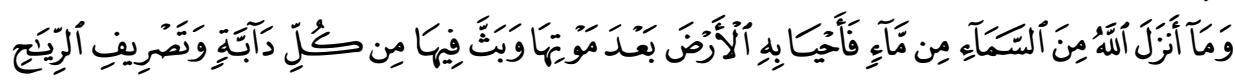

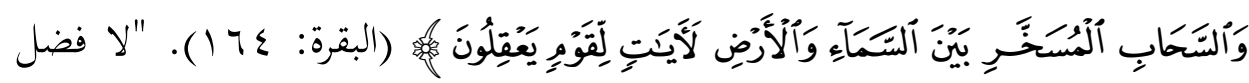

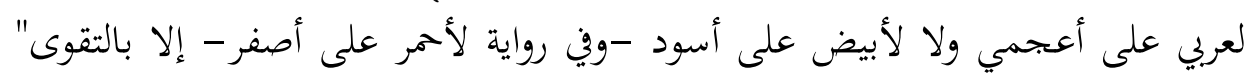

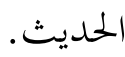

فالآيات تدل على أن التنوع الكوني الطبيعي الحي والجامد، له مشروعيته الوجودية

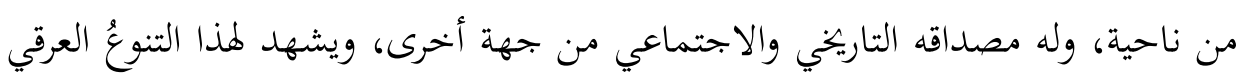

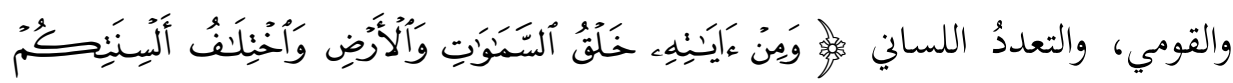

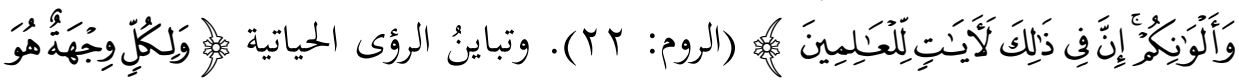

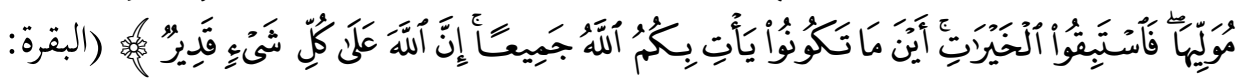

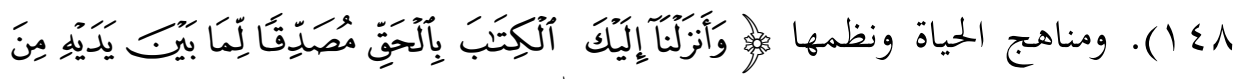

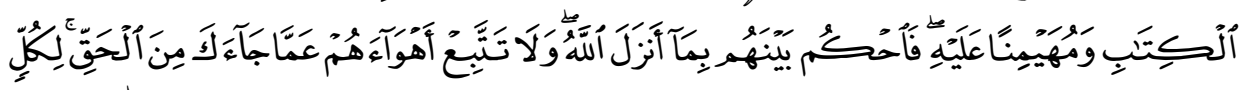

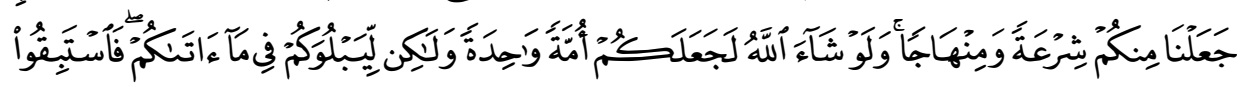

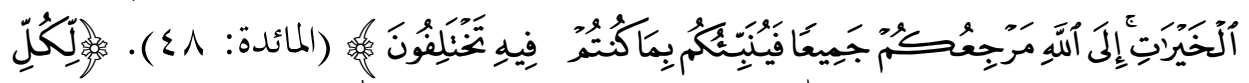

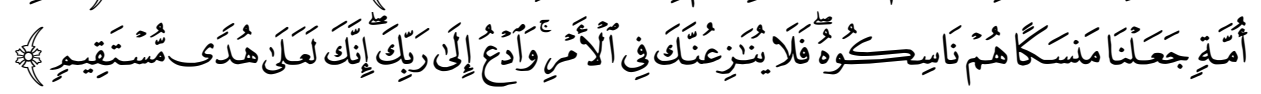
(الحج: (TV)

فالكون والأرض كأغما مسـاحة شـاملة واسعة تحوي طرقاً لكل أفقها، والإنسان

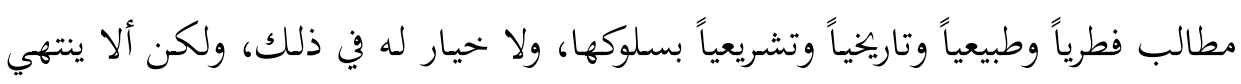

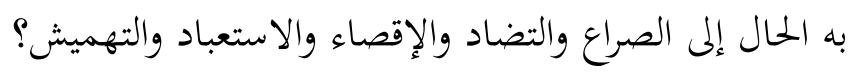

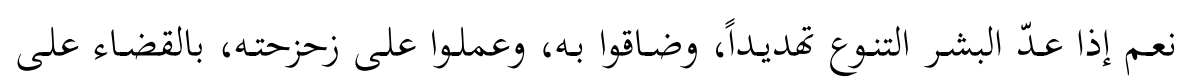

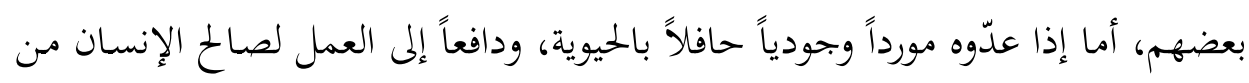

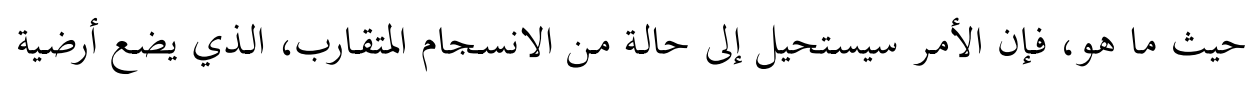

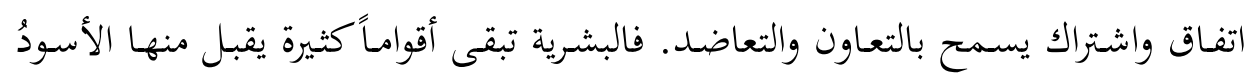

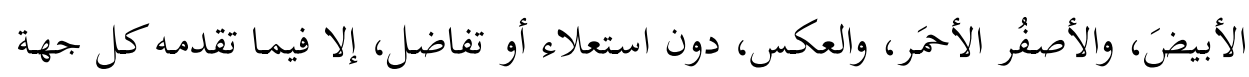




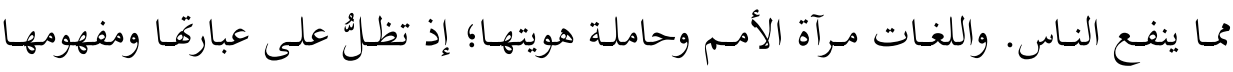

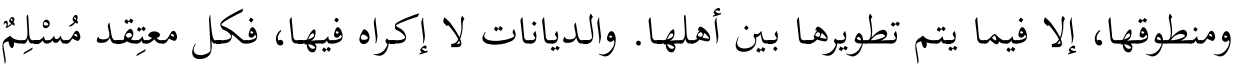

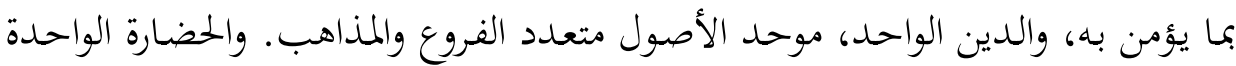

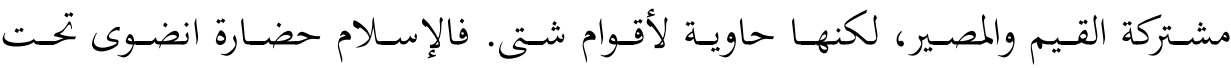

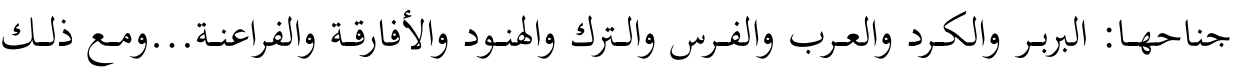

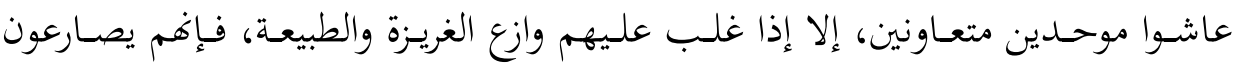

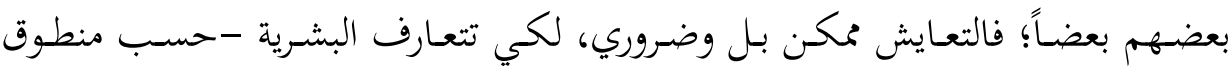

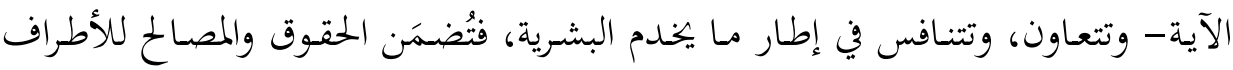

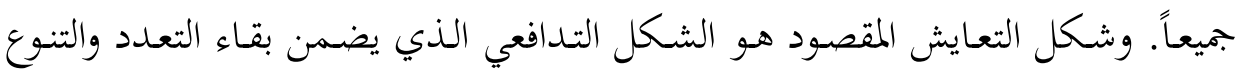

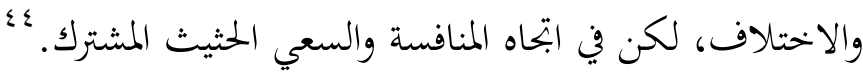

\section{r. الضوابط الإنسانية للتعارف، والاعتراف المتبادل:}

يستحيل التعارف في ظل النفسية المتوجسة من الآخر، والناظرة إليه بعين الدونية

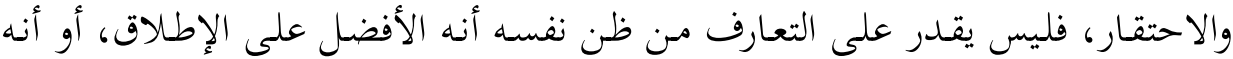

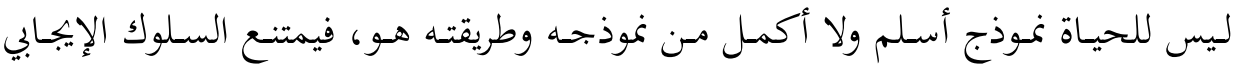

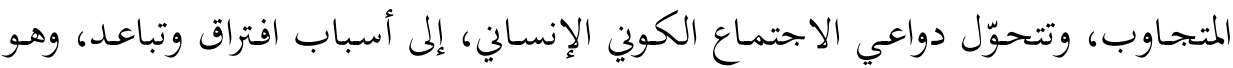

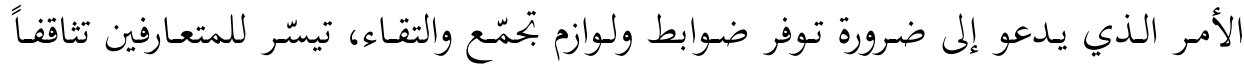

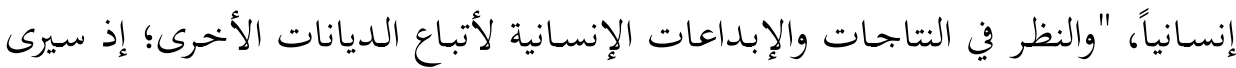

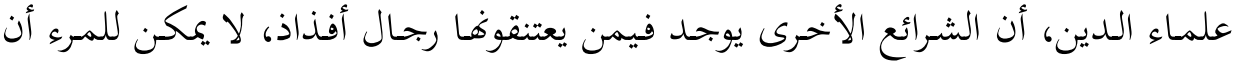

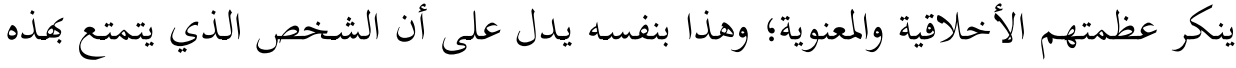

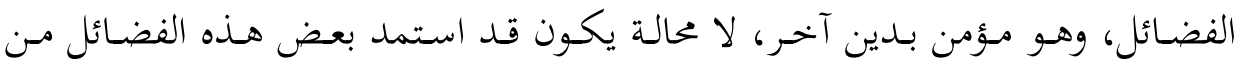

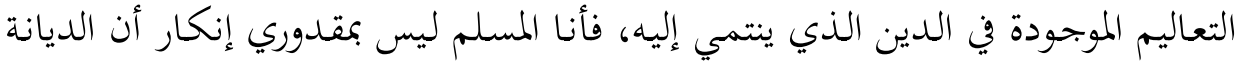

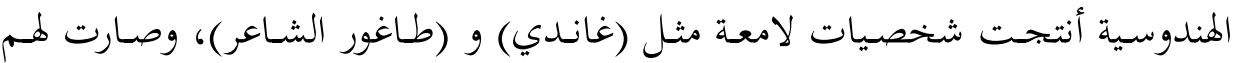

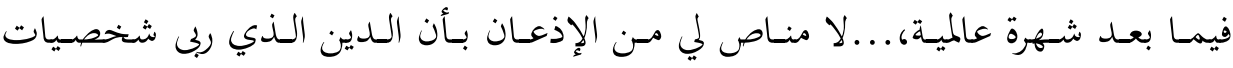

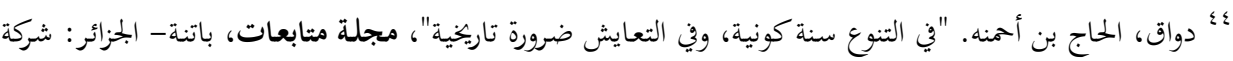

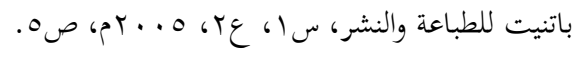




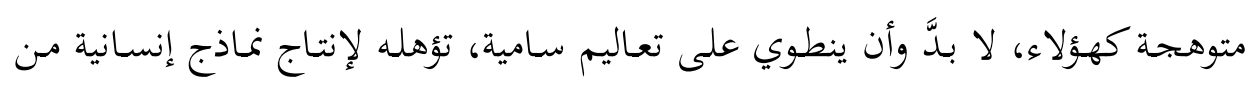

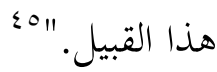

إنّ أبلغ توطئة للتثاقف المتأسِس على التعارف، التسليمُ بأن الشرائع الأخرى المكونة

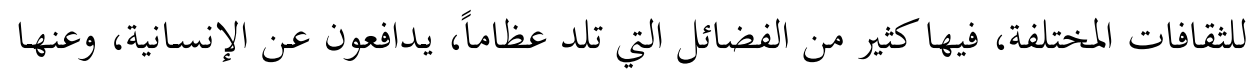

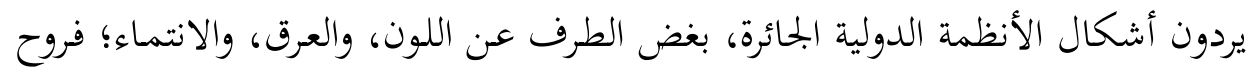

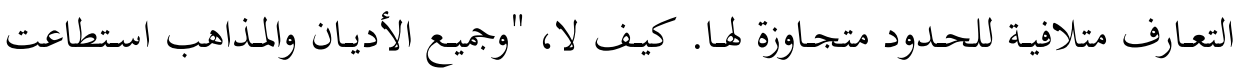
على مدى قرون أن تبعث البهجة والسرور، والأمل والطمأنينة، في نفوس الكثيرين، وأن والن

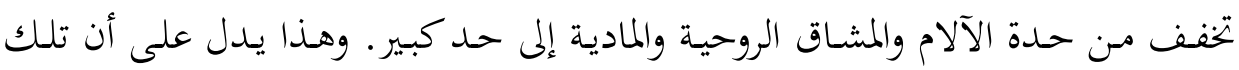

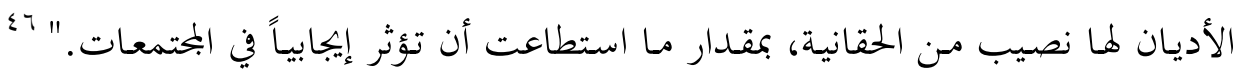

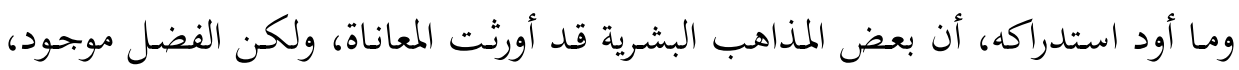
ويسع المقدرة على بناء أرض التثاقف والاجتماع، كما يوجد مقابله من يعمل على دفن كل اعتبارات التلاقي والتفاهم.

التأسيس السابق يكرس استعدادات تنفي التعصب والتشرنق على الذات، ولا يولد

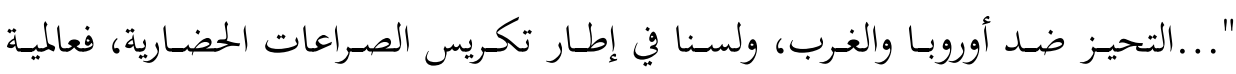
الإسـام (وخروجنـا) مـن قبلُ بالرسالة إلى النـاس كافة، ودبحنـا بين الحضـارات والثقافـات

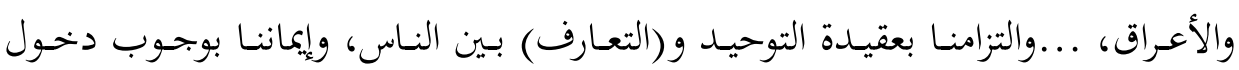
البشرية في السلم (كافة)، كل هذا يجعلنا لا ننطلق من منطق التحيز، بل نعذر الغير إن تحيز ضدنا -فللغير - من موروثه التاريخي ونسقه الحضاري ولاهوته الديني، ما قد يدفعه لذلك.

الدخول في السمم من أوجب ضوابط التعارف، وأكثر آلياته إلحاحاً؛ وجودياً، لبقاء

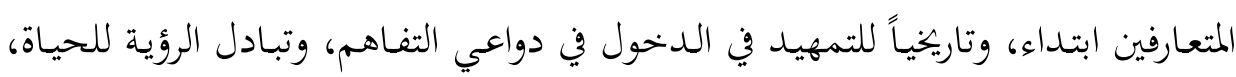
•؛ ملكيان، مصطفى. العقلانية والمعنوية، مقاربات في فلسفة الدين، ترجمة: عبد الجبار الرفاعي، بيروت: دار

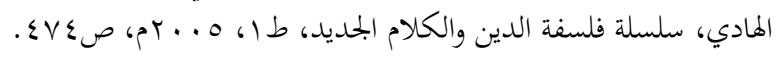

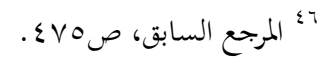

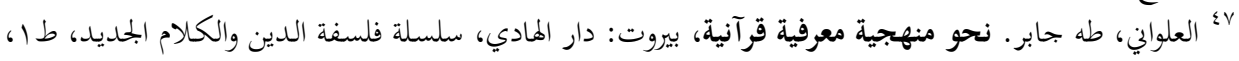




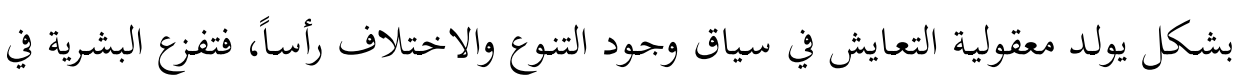

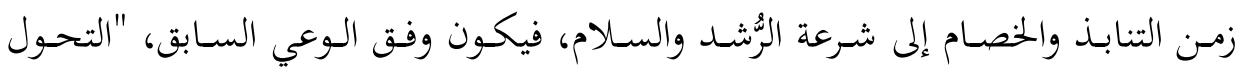

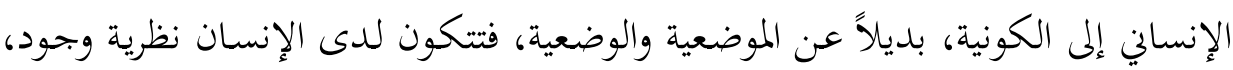

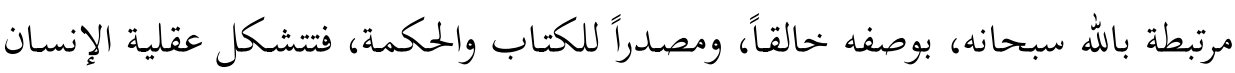

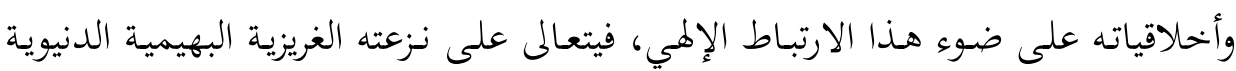

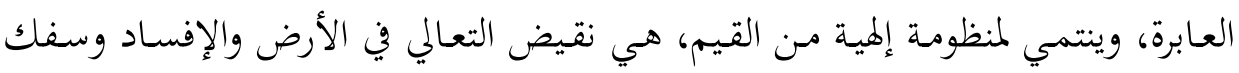

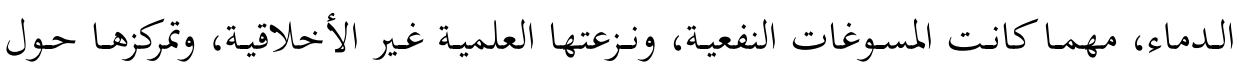

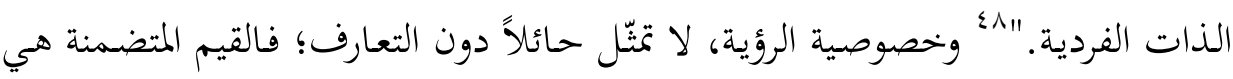

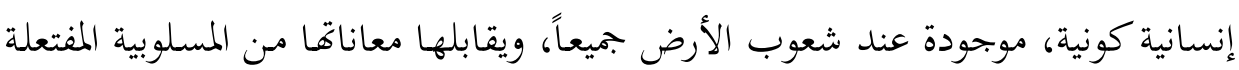

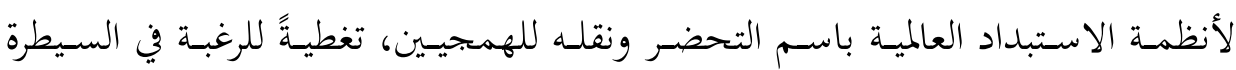
والتعدي.

ولـو خـيرت الإنسـانية -بعيــاً عـن أسـاليب التمويـه والدعايـة- بـين قيم متجـاوزة

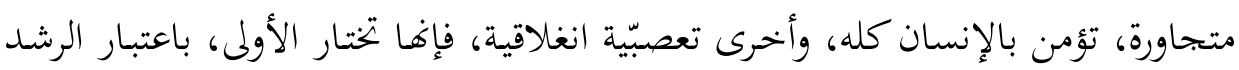

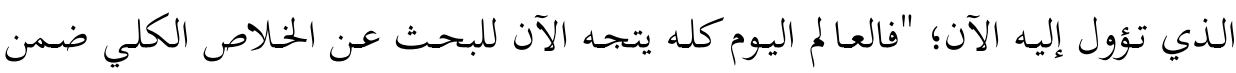

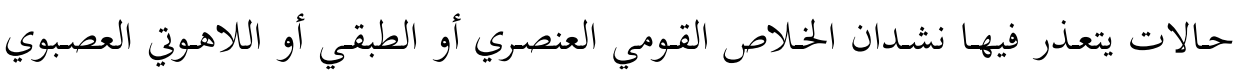

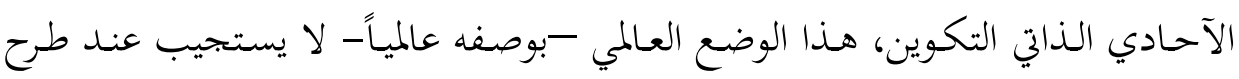

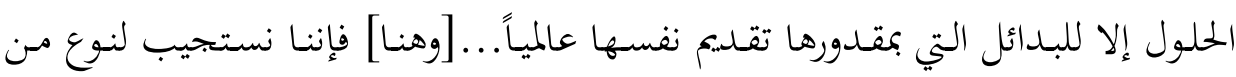

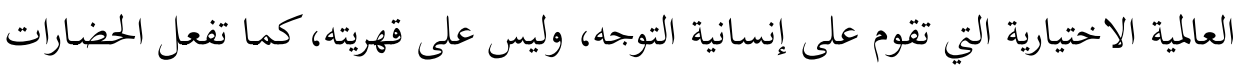
المادية التي تود تفصيل عالم على قياساتا الذاتية وبنهج مصالحها. "9.

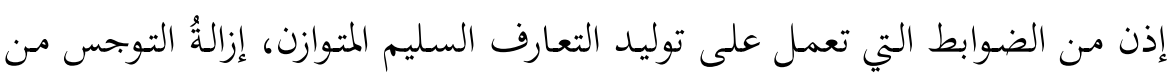

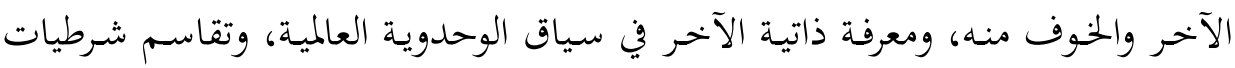

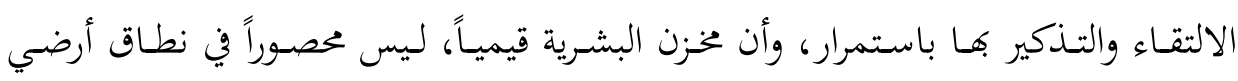

^؛ حاج ممد، حممد أبو القاسم. الأزمة الفكرية والحضارية في الواقع العربي الراهن، بيروت: دار الهادي، طا، 
واحسد، بل هو متوزع في جنبات الوجود العريضـة، ثم خطاب الإنسان للإنسان، لأنه الإنه

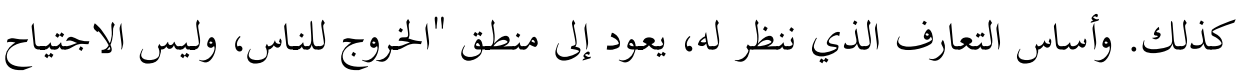

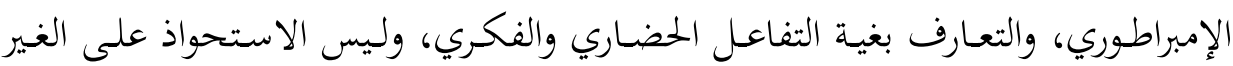
وفب ثرواتم، والدعوة للتوحيد وليس الإكراه." ل•

\section{r. فلسفة نبذ العنف مهاد التعارف:}

تكاملت الإنسانية في مسيرةًا الحضارية، إلى أن بلغ بهـا الحسال مطاولة النجوم كما

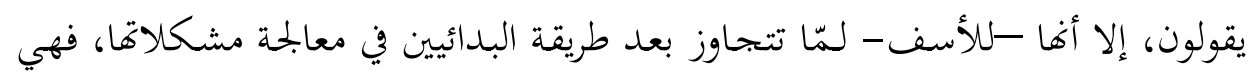

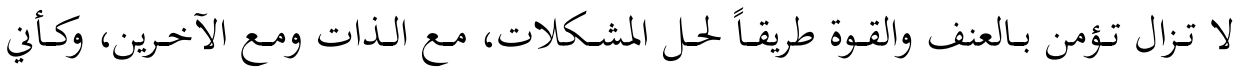

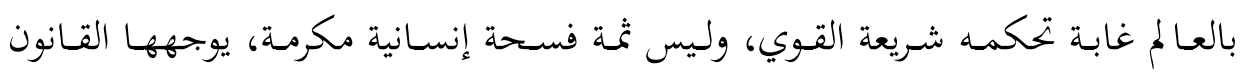

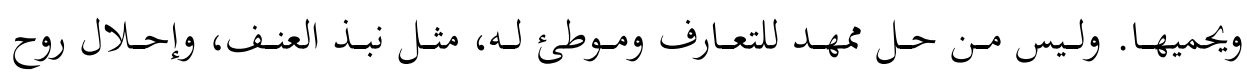

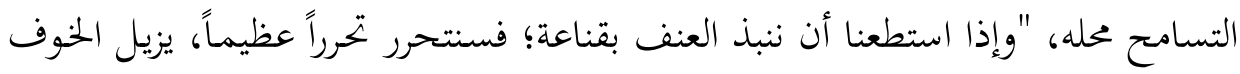

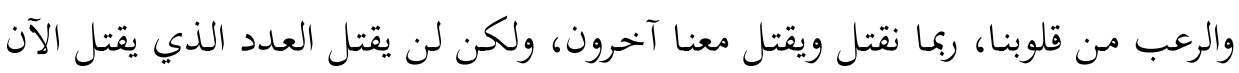
بسبب استخدام العنف.

وحتى الآن لم يبحث مقدار القوة التي يمكن للإنسان أن يمتلكها إذا نبذ العنف، وكم

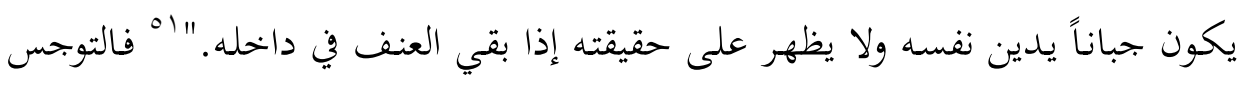

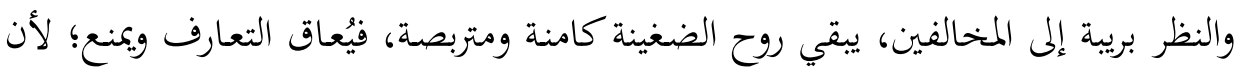

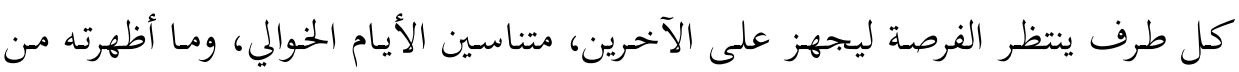

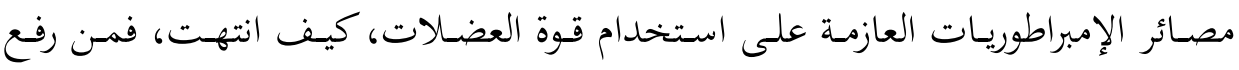

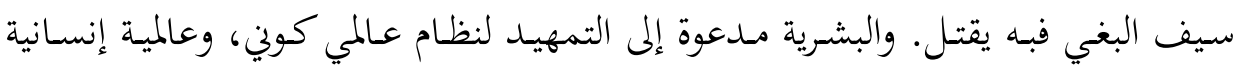

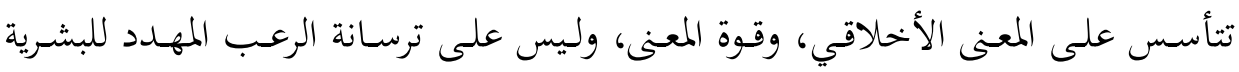

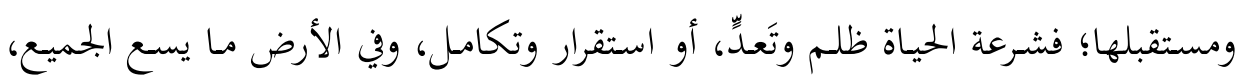
لو ما ضيق الأنفس وتبرمها وأنانيتها.

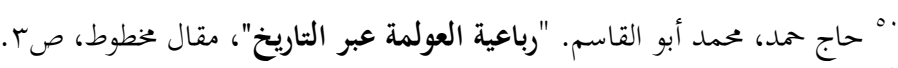

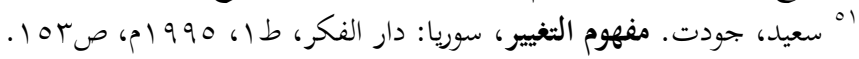




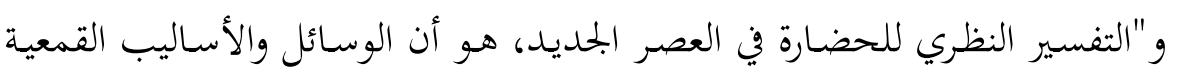

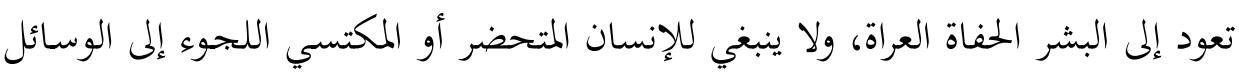

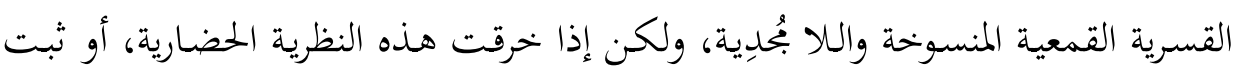

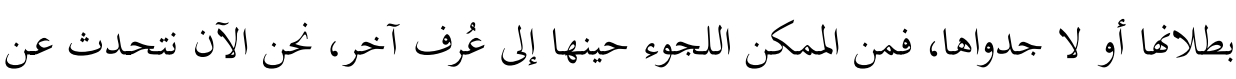

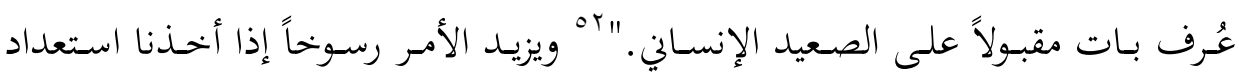

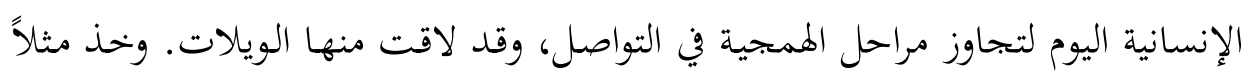

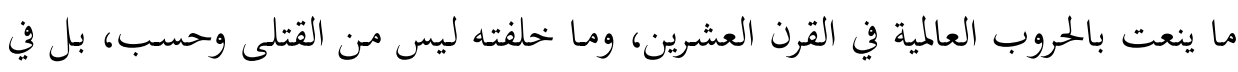

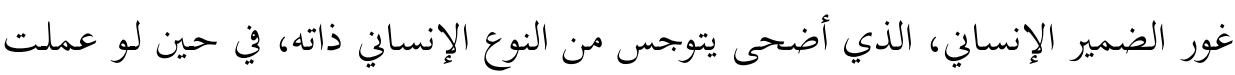

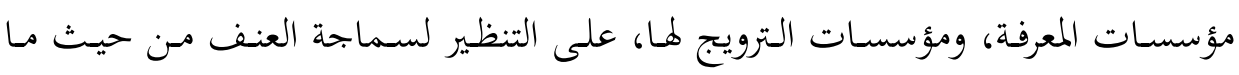
هو، فستتمهد أرض صلبة، يقف عليها الضمير الكوني، بطمأنينة وثقة في قابل الأيام. وعادة ما يشار إلى الوعي السالف النابذ للعنف، على أنه مراوغة تكتيكية، وليس

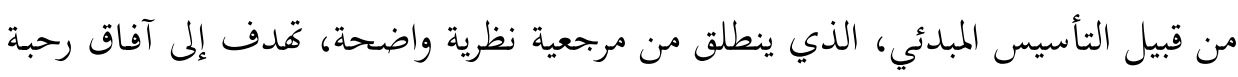

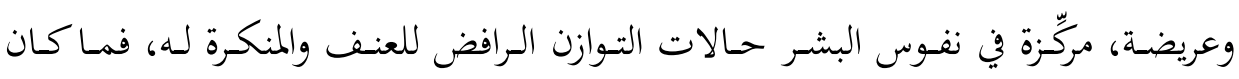

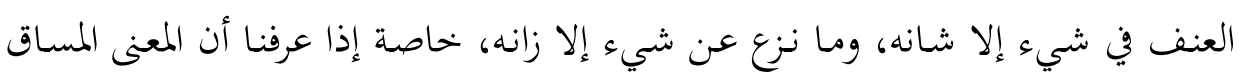

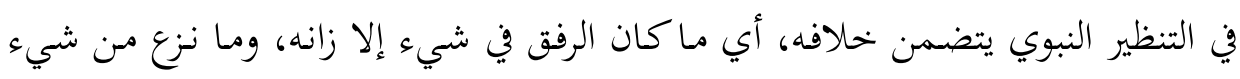

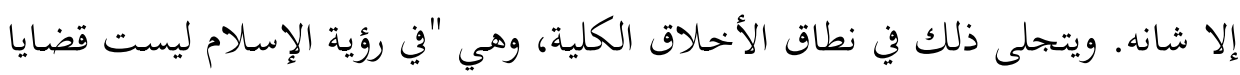

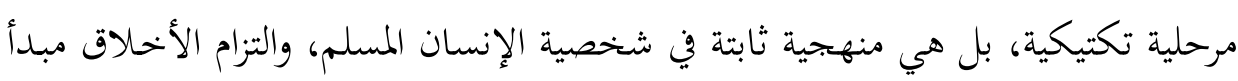

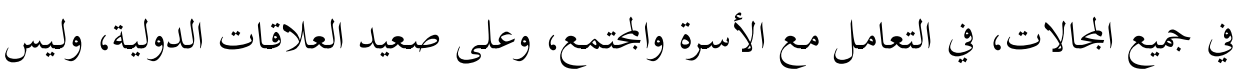

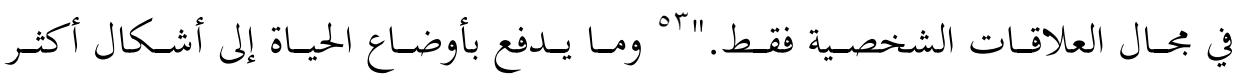

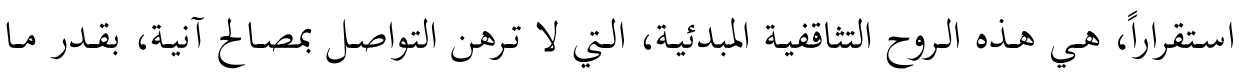

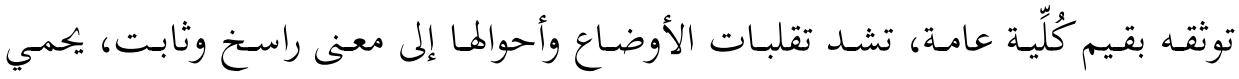
البشر لأفم كذلك، وليس لاعتبارات أخرى متقلبة.

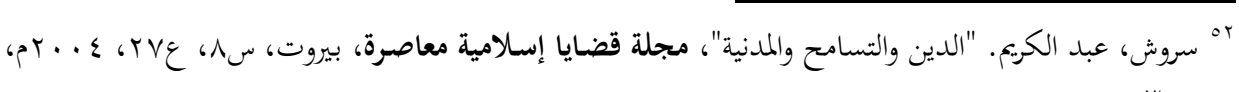

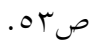

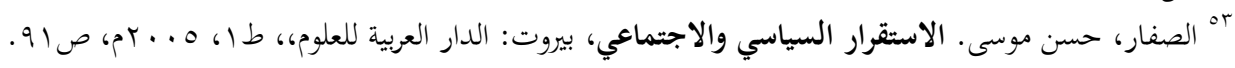




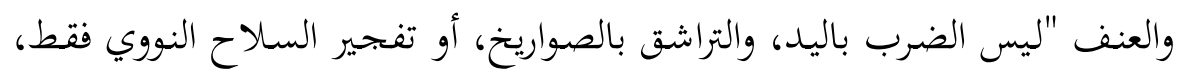

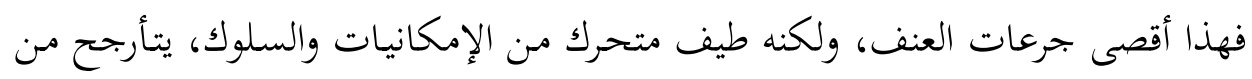

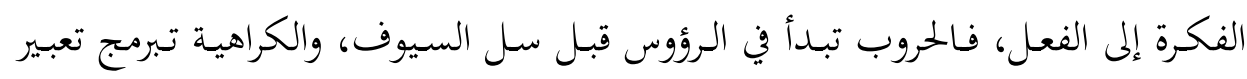

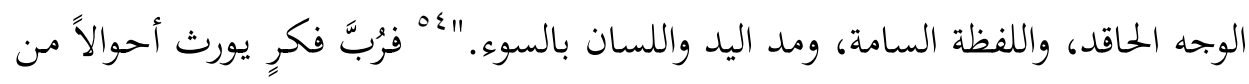

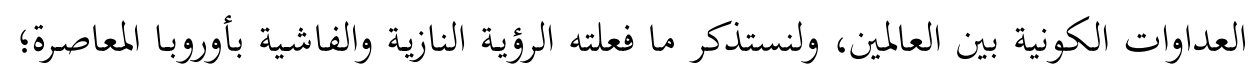

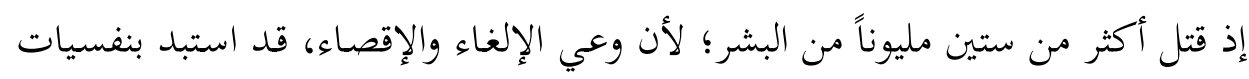

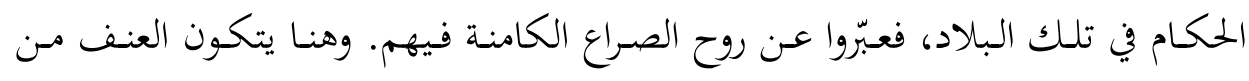

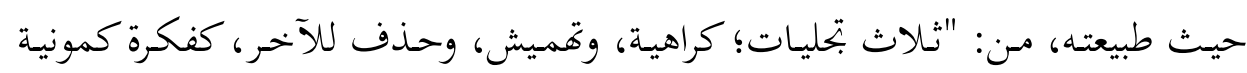

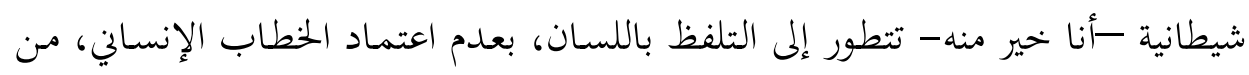

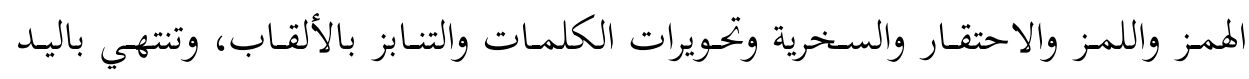

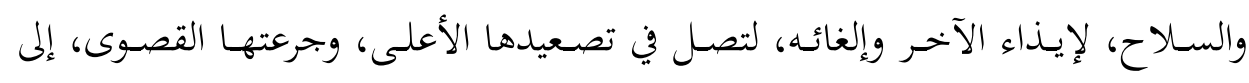

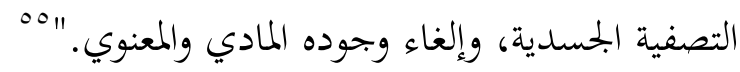

خاتمة:

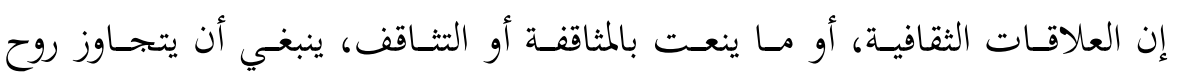

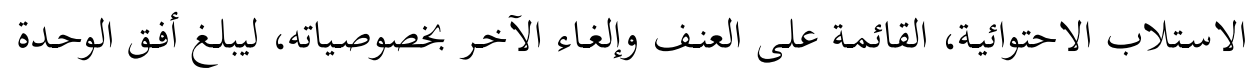

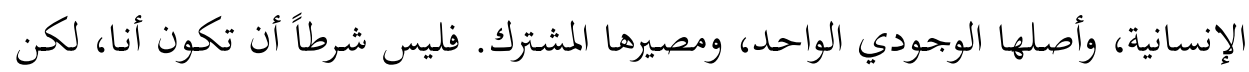

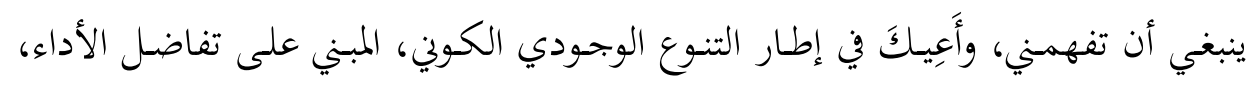

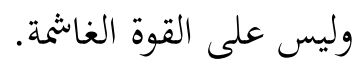

وكلما ترنحت البشرية في بتحاربها التاريخية بين ممارسات متعالية مبتعدة عن الهداية

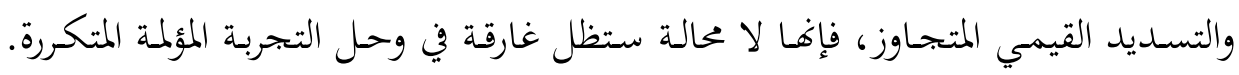
فالأزمة الجوهرية لا تتمثل في النظريات المفسرة للصلات الحضارية والثقافية أو المكونة لها،

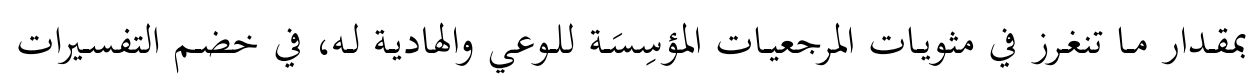

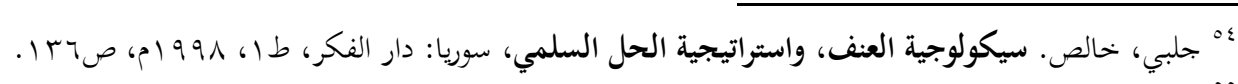

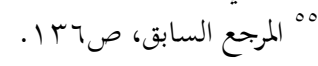


المختلفة. لذا نحن في إطار المدرسة التوحيدية المتغذية من المعين الإلهي، بحاجة إلى استقراء

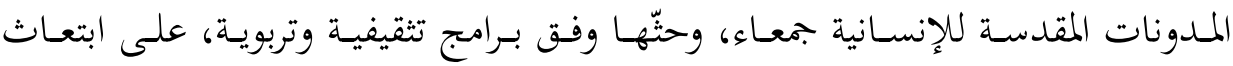

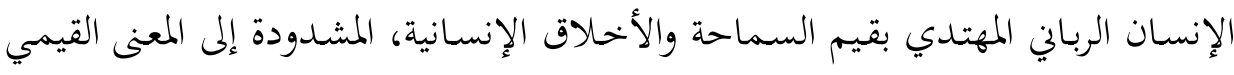
الأخلاقي والجمالي، الحافظ لكرامة الإنسان.

وإذا تتبعنا مسار الثقافات الروحية الكبرى في تاريخ الإنسان الطويل، وجداناها تلحّ

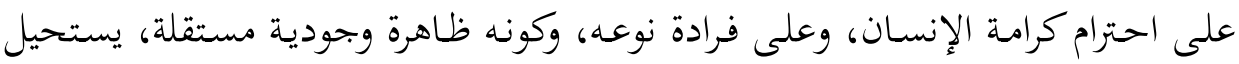

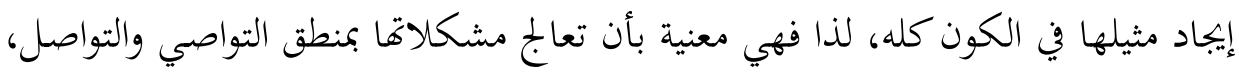

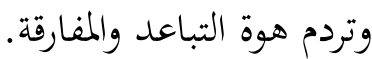

إن العرف العقلائي وما أجمع عليه كل الواعين من الناس، يجعل البشر مطالبين أكثر

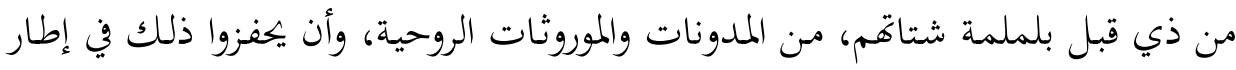

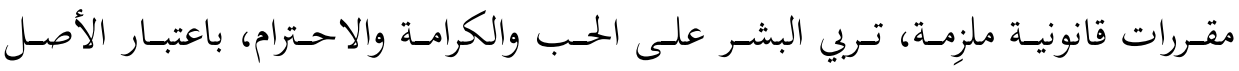

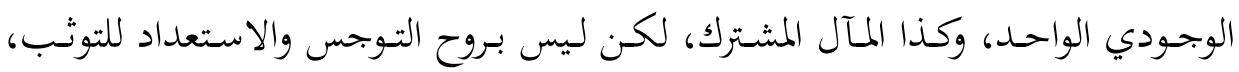

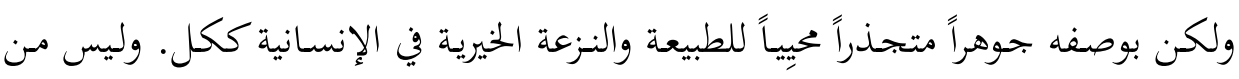

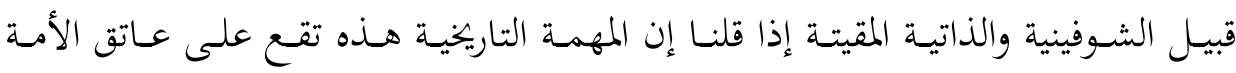

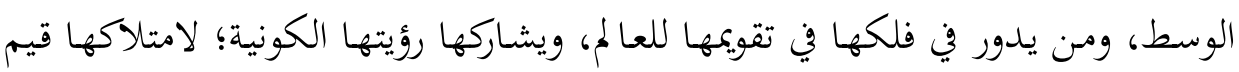

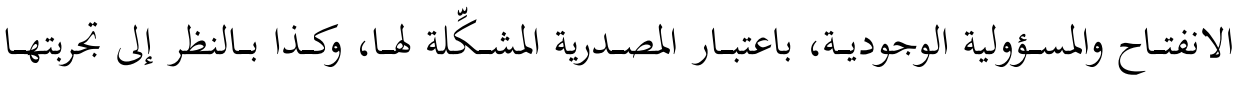

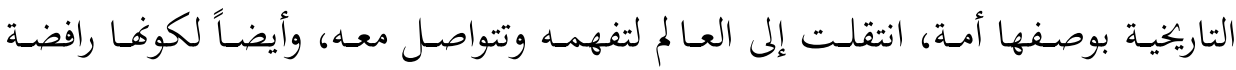

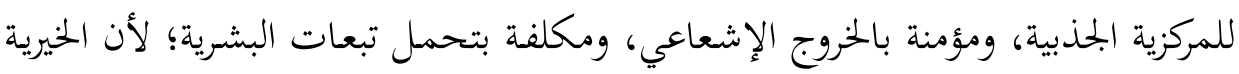

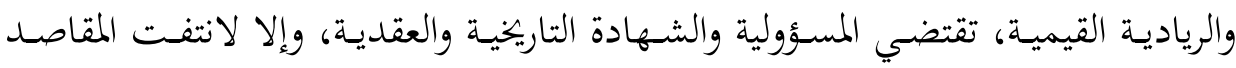

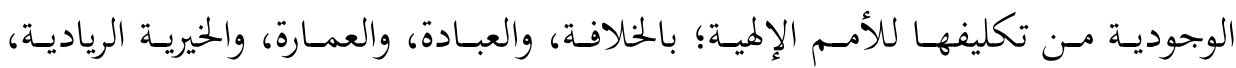
والشهادة.وكل يعمل على شاكلته. 